Characteristics of Thin-Skinned

Style of Deformation in the

Southern Appalachians, and

Potential Hydrocarbon Traps

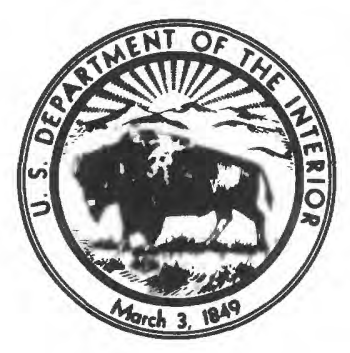

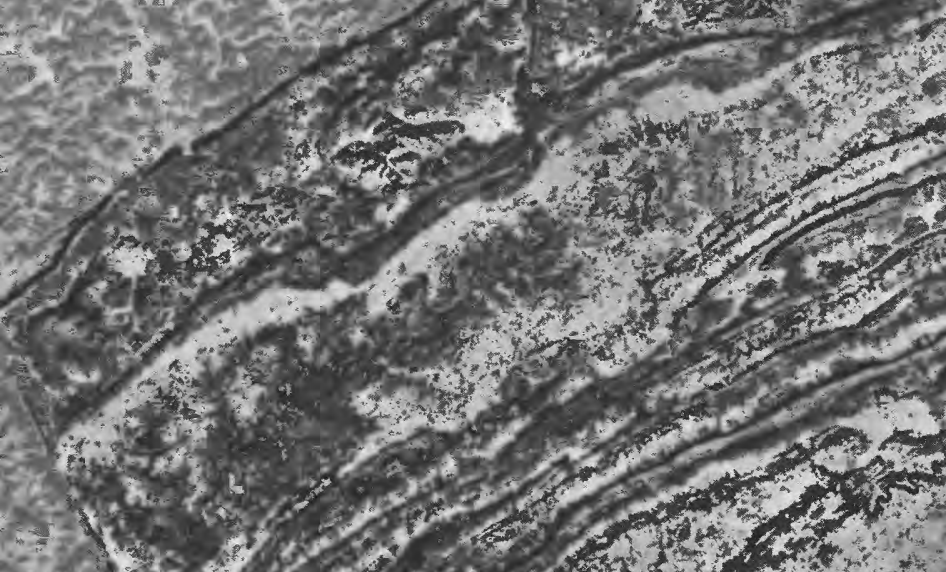

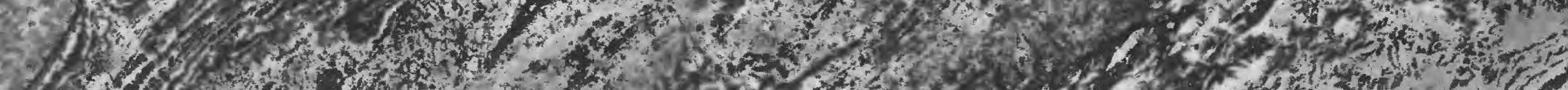

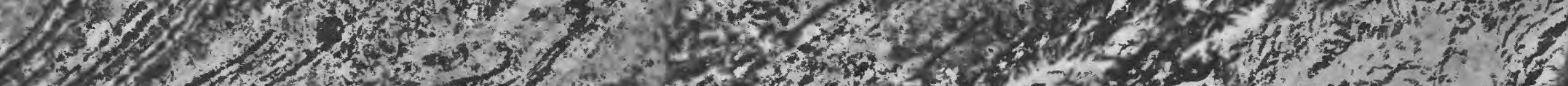

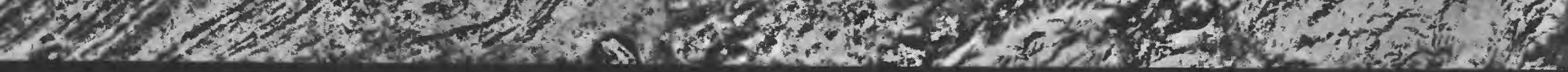

GEOLOGICAL SURVEY PROFESSIONAL PAPER 1018 


\section{Characteristics of Thin-Skinned Style of Deformation in the Southern Appalachians, and Potential Hydrocarbon Traps}

By LEONARD D. HARRIS and ROBERT C. MILICI

GEOLOGICAL S URVEY PROFESSIONAL PAPER 1018

Description of and field guide to large- and small-scale features of thin-skinned tectonics in the southern Appalachians, and a discussion of hydrocarbon production and potential

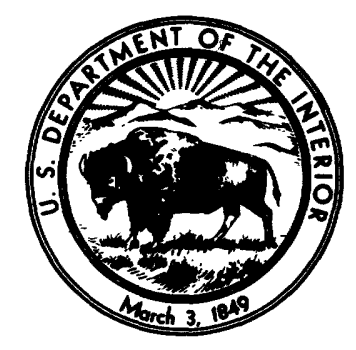




\section{UNITED STATES DEPARTMENT OF THE INTERIOR}

JAMES G. WATT, Secretary

\section{GEOLOGICAL SURVEY}

Doyle G. Frederick, Acting Director

First printing 1977

Second printing 1981

\section{Library of Congress Cataloging in Publication Data}

Harris, Leonard D.

Characteristics of thin-skinned style of deformation in the southern Appalachians, and potential hydrocarbon traps.

(Geological Survey professional paper ; 1018)

Bibliography: $\mathbf{p}$.

Supt. of Docs. no.: I 19.16:1018

1. Rock deformation. 2. Geology-Appalachian Mountains. 3. Petroleum--Geology-Appalachian Mountains.

I. Milici, Robert C., 1931- joint author.

II. Title: Characteristics of thin-skinned style of deformation in the southern Appalachians . . III. Series: United States. Geological Survey. Professional paper ; 1018.

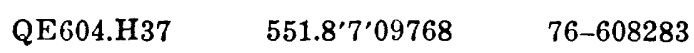

For sale by the Distribution Branch, U.S. Geological Survey, 604 South Pickett Street, Alexandria, VA 22304 


\section{CONTENTS}

Abstract

Introduction -

Regional framework -

Tectonic model of thin-skinned deformation

Characteristics of a décollement

Anatomy of a décollement

Typical surficial structures

Oil and gas production

Oil and gas potential

Future oil and gas possibilities -.....

Field guide to structural features of the southern Appalachians in parts of

Tennessee and southwest Virginia

Road log, Chattanooga to Knoxville, Tenn

Stop 1, Exposure of the Cumberland Plateau décollement at Dunlap, Tenn

Stops 2A and 2B, An example of splay thrusting along the toe of the

Ozone décollement

Road log, Knoxville, Tenn., to Cumberland Gap, Tenn.-Va.-Ky _........

Stop 3, The lower level Copper Creek décollement at Bull Run Ridge --

Stop 4, The Pine Mountain thrust sheet

Stop 5, Vertical Pennsylvanian ribs in the northwest limb of the Powell

Valley anticline

Stop 6, Exposure of the Pine Mountain thrust fault on Pine Mountain.-

Stop 7, The Chestnut Ridge fenster

Road log, Cumberland Gap, Tenn.-Va.-Ky., to Gate City, Va

Stop 8, Exposure of the Hunter Valley thrust fault near Duffield, Va --

\section{ILLUSTRATIONS}

[Plates are in pocket]

Plate 1. Maps showing generalized geology, conodont color alteration indexes, and areas of oil and gas production in the southern Appalachians.

2. Structure map and cross sections of the Pine Mountain thrust sheet, Kentucky, Tennessee, and Virginia.

3. Diagrams showing structural details of the Cumberland Plateau décollement zone at Dunlap, Tenn.

4. Diagrams showing structural details of the Copper Creek décollement zone at Bull Run Ridge, Tenn.

5. Diagrams showing the anatomy of a décollement zone in the southern Appalachians.

6. Structure section from the Appalachian Plateaus to the Blue Ridge, Tenn.

7. Geologic cross sections of the Sequatchie and Cardiff Ridge anticlines, Tennessee:

8. Diagrams showing structural details along the toe of the Ozone décollement zone near Ozone, Tenn.

9. Diagrams showing structural details in the Hunter Valley décollement zone near Duffield, Va. 
FIGURE 1. Seismic profile and interpretive structure section of part of the Valley and Ridge of east Tennessee

2. Diagram showing restored model of the Paleozoic sedimentary basin for east Tennessee -

3. Stratigraphic nomenclature used in parts of east Tennessee and southwest Virginia

4. Diagrams showing the initial form of the Pine Mountain décollement system -...-..-

5. Block diagram of the component parts of the initial Pine Mountain thrust sheet

6. Geologic map and structure section of the Chestnut Ridge fenster area -

7. Diagrams showing the tectonic thinning of the Rome Formation.-

8. Diagrams showing the development of the southern Appalachian décollement zone

9. Diagrams showing the development of the Powell Valley anticline -

10. Cross section showing folding of thrust faults

11. Cross section showing that subsurface duplication warped the Pine Mountain plate

12. Map showing possible projection of Plateaus rocks beneath the Valley and Ridge -

13. Map showing field-trip routes

Page 


\title{
CHARACTERISTICS OF THIN-SKINNED STYLE OF DEFORMATION IN THE SOUTHERN APPALACHIANS, AND POTENTIAL HYDROCARBON TRAPS
}

\author{
By Leonard D. Harris ${ }^{1}$ and Robert C. Milici ${ }^{2}$
}

\begin{abstract}
Rootless folds and gently to steeply dipping thrust faults, which, at depth, join a master décollement near the sedimentary rock-basement contact, are the key tectonic features of the southern Valley and Ridge and Appalachian Plateaus provinces. The master décollement is a low-angle thrust in basement rocks beneath the Blue Ridge that extends westward as a detachment fault in the sedimentary rocks of the two provinces. Because the major detachment zone west of the Blue Ridge is near the sedimentary rock-basement contact, the earliest décollement mimicked the geometry of the Paleozoic sedimentary basin. Reconstruction of that basin indicates that it consisted of a thick clastic sequence on the east bordered by a thinner shallow shelf sequence on the west. As the detachment grew, it followed the sedimentary rockbasement contact as a subhorizontal fault through the base of the thick eastern sequence, was deflected upward along the steeply sloping shelf edge to the west, and continued westward some distance as a subhorizontal detachment beneath the shelf, where it ramped upwards to a higher stratigraphic level (Devonian to Pennsylvanian) and continued again as a subhorizontal detachment fault. The décollement dies out westward in the Plateaus either in minor splays and smallscale duplication within a décollement zone or in a single large splay anticline that deflects the fault to the surface.

Exposed décollement zones in the Plateaus have a recognizable deformational pattern that consists of a basal detachment fault overlain by a lower broken-formation zone and an upper fractured zone. In the Valley and Ridge, the lower broken-formation zone rarely occurs above décollements; more commonly, the upper fractured zone or relatively undeformed rocks are present above the detachment fault. This regional variation above detachment faults is produced by obstructions forming during movement within the décollement zone. The obstructions deflect the basal detachment upwards, abandoning large parts of the décollement zone in the subsurface. The abandoning process appears to have controlled the thickness and distribution of Cambrian formations on the surface and in the subsurface in east Tennessee. A field guide to large- and small-scale features of thin-skinned tectonics is provided.

En masse westward movement of rock above the initial décollement, up the tectonic ramps and the relatively steep slope between the shelf and the basin deep, resulted in the formation of a series of rootless anticlines and synclines. In
\end{abstract}

1 U.S. Geological Survey, Reston, Va. 22092.

2 Tennessee Division of Geology, Knoxville, Tenn. 37919. Work done under U.S. Geological Survey grant No. 14-08-0001-G259. contrast, the present structural pattern in the Valley and Ridge is dominated by thrust faults alternating with synclines. The alteration of the original structural pattern to the present pattern was accomplished through a west-to-east sequential imbrication.

The sharp surface change, at the Allegheny structural front, from more deformed rocks of the Valley and Ridge to the less deformed rocks of the Appalachian Plateaus is clearly a surficial feature. Drilling and local seismic data suggest that the deformed rocks of the Valley and Ridge have moved westward and have buried a 4 -mile $(6.4-\mathrm{km})$ toe or projection of Plateaus rocks along much of the structural front in southwest Virginia and Tennessee. Because much of the Paleozoic section is contained within the projection, it is a favorable site to test several different stratigraphic levels for potential commercial hydrocarbon production.

Five distinct changes in color of conodonts have been utilized to estimate the oil and gas potential of the southern Appalachians. An Ordovician isograd map suggests that most of the Plateaus, but only a small part of the Valley and Ridge in Tennessee and adjacent parts of Virginia, have a potential for commercial praduction of oil. The same data, however, show that a much larger area, including most of the Valley and Ridge, has a potential for natural-gas production.

\section{INTRODUCTION 3}

Structure in the southern Valley and Ridge is dominated by a series of en echelon thrust faults alternating with synclines. Outcrop patterns of fault traces and the widespread occurrence of fensters suggested to earlier workers (Hayes, 1891; Campbell and others, 1925; Butts, 1927) that many of these thrust faults, rather than dipping steeply into basement, actually flatten at depth to form lowangle bedding-plane thrusts having miles of northwest displacement. Rich (1934) observed that although the area was completely broken by thrust faults, none of these faults brought basement rocks to the surface. He suggested, therefore, that thrusts in the Appalachian Valley are entirely confined to the sedimentary rocks and that movement of the

3 The nomenclature used in this text and shown on the chart (fig. 3) is from many sources and may or may not agree with the U.S. Geological Survey usage. 
thrust sheets to the northwest produced anticlines simply by duplication of beds. Folds of this type are rootless structures confined to individual thrust sheets, and rocks below the thrust sheet are left relatively undisturbed. This particular style of deformation, because it has been confined to the sedimentary sequence above the basement complex, has been termed "thin-skinned" (Rodgers, 1949).

During the past 30 years or so, limited drilling along the extreme west edge of the Valley and Ridge and parts of the Appalachian Plateaus in the Pine Mountain thrust area has tended to confirm Rich's hypothesis of a thin-skinned style of deformation (Harris, 1970). However, no wells drilled in the Pine Mountain area actually intercepted basement, and the question of basement involvement in thinskinned deformation remained unresolved. In addition, because drilling was confined to a relatively small area along the western edge of the Valley and Ridge, valid three-dimensional data were not available to confirm the applicability of the concept to most of the southern Valley and Ridge. Thus, until about 1964, serious questions concerning the style of deformation and the area of its applicability remained unanswered (Lowry, 1964). In that year, however, Gwinn (1964) published a summary of data generated by major oil and gas companies in an exploration program in the central Appalachian States of Virginia, West Virginia, Maryland, and Pennsylvania. In that area, regional seismic profiles plus deep drilling have confirmed that the thinskinned style of deformation, as outlined by Rich (1934), was indeed valid (Jacobeen and Kanes, 1974). Nonexposed thrust faults, all confined to the sedimentary sequence, were found in the subsurface, and folds were shown to be surficial features confined to individual thrust sheets. More recently, limited seismic data in the southern Appalachians have verified the applicability of thin-skinned deformation to that area (Harris, 1976) (fig. 1).

This paper is an attempt to focus attention on the more important characteristics of the thin-skinned

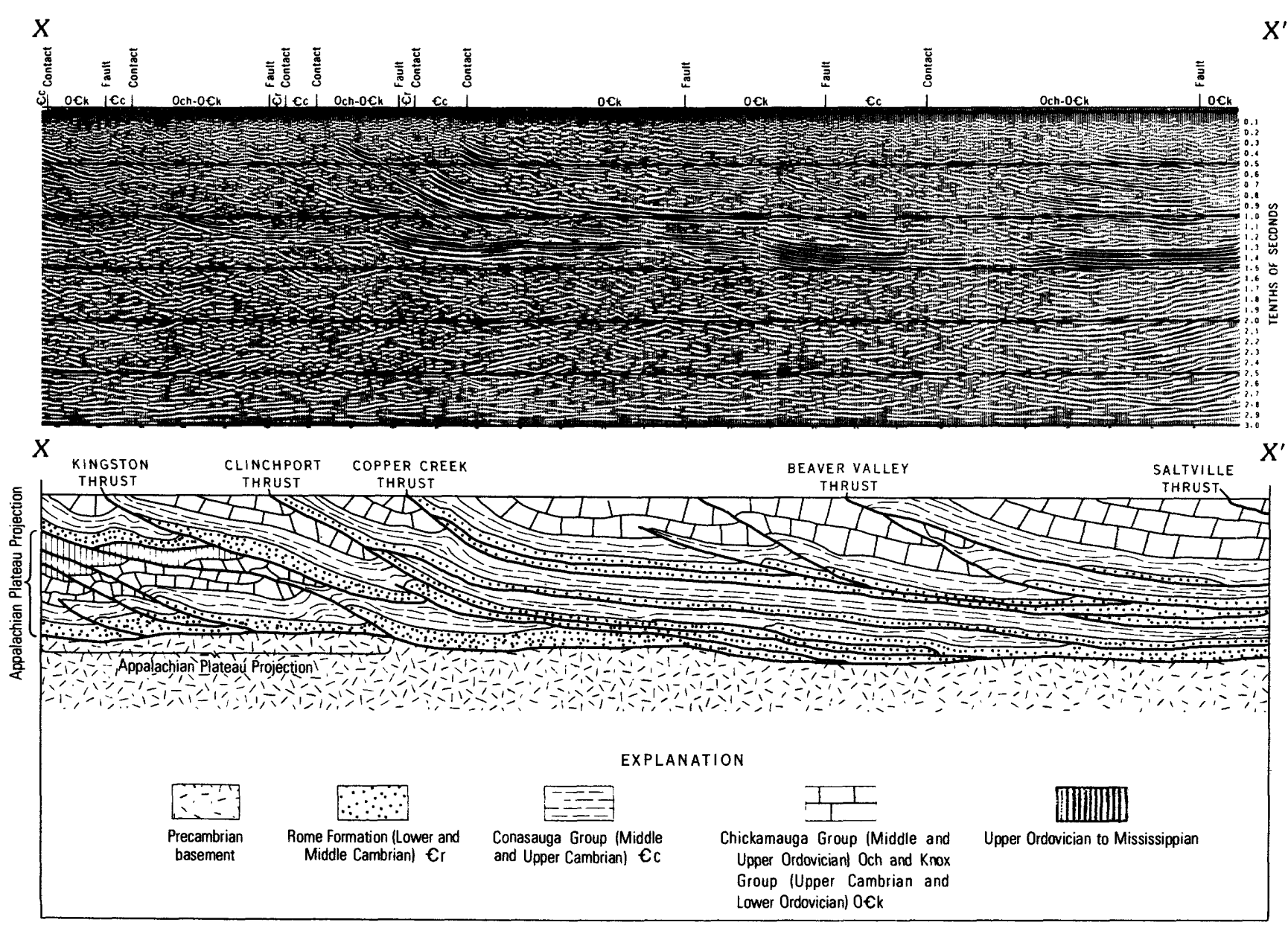

Figure 1.-Seismic profile and interpretative structure section of a 20-mile $(32-\mathrm{km})$ segment of the Valley and Ridge of east Tennessee. From Harris (1976). Line of section shown on plate $1 A$. 
style of deformation in the southern Appalachians by presenting a model to illustrate the regional anatomy of a décollement and to identify likely structures that need additional investigation as possible prospects for hydrocarbon accumulation.

\section{REGIONAL FRAMEWORK}

Reconstruction of the configuration of the original sedimentary basin constituting the present southern Valley and Ridge and adjacent parts of the Appalachian Plateaus is hampered by many regionally extensive thrust faults (pl. 1A). These faults, which have displacements on the order of miles, obscure regional facies trends by burying large segments of the original basin and by bringing into juxtaposition facies that accumulated in widely separate parts of the basin. We constructed a generalized basin model (fig. 2) by estimating the amount of shortening across the Valley and Ridge in Tennessee and by moving individual thrust sheets back to their assumed points of origin. Although the restored basin model is a generalization, it focuses attention on the major characteristics of the basin.

Paleozoic rocks ranging in age from Cambrian to Pennsylvanian in the southern Valley and Ridge form a wedge-shaped sequence that thins markedly from east to west (figs. 2 and 3). In general, this sequence records three major depositional episodes, each separated by regional unconformities. These episodes are represented by a Cambrian through Lower Ordovician unit, a Middle Ordovician through possibly Lower Devonian unit, and an Upper Devonian through Pennsylvanian unit.

The Cambrian through Lower Ordovician depositional unit is a westward-transgressive sequence that gradually changes upward from dominantly clastic to dominantly carbonate. The initial deposits (Chilhowee Group) consist of nearshore shallow marine sandstone interfingering with off shore relatively deeper water shale and siltstone (Whisonant, 1974). In general, as trangression progressed westward, the character of the sandstone changed upward; the basal sandstones are conglomeratic and arkosic, whereas the uppermost sandstones are orthoquartzites. Clastic sedimentation was followed by the formation of a shallow carbonate bank, the Shady Dolomite. Until recently, the Shady was considered to be Early Cambrian in age; however, Willoughby (1976) pointed out that it contains both an Early and Middle Cambrian fauna. Evidently the terrigenous clastic rocks of the Rome Formation were deposited in an intertidal and shallow subtidal environment west of the carbonate bank of the Shady.

After the deposition of the Rome Formation (Lower and Middle Cambrian), the basin gradually subsided so that offshore marine environments prevailed throughout the area. During this period, when the source for clastic materials was to the west and north, a relatively deep water lagoonal sequence of shale, siltstone, and thin-bedded limestone (Conasauga Group) accumulated in the western part of the present Valley and Ridge and the adjacent Appalachian Plateaus (Milici and others, 1973). To the east, this fine-grained clastic sequence interfingered with and was gradually supplanted by shallow marine carbonate shelf units (Conasauga Group). During the Late Cambrian, the eastern carbonate shelf sequence (Knox Group) transgressed westward and eventually covered the entire Appalachian basin. The Knox Group is mainly dolomite in the central and western parts of the Valley and Ridge and limestone in the easternmost part. Regionally, during Late Cambrian and Early Ordovician time, the distribution of dolomite and limestone was related to the development of a subtidal salinity system over much of the Southern and Eastern United States (Harris, 1973). Sedimentation apparently ended in Early Ordovician time when uplift of much of the Eastern United States formed a carbonate lowland on which karst topography was widespread.

Uplift and erosion associated with the development of the regional unconformity during Early Ordovician time were greater in the Piedmont than in the Valley and Ridge because Lower Ordovician carbonate rocks are present beneath the unconformity in the Valley and Ridge, whereas Lower Cambrian clastic and volcanic materials are found beneath the unconformity in the Piedmont (Brown, 1970; Pavlides and others, 1974).

From Middle Ordovician to Pennsylvanian time, the major source for clastic rocks in the developing southern Appalachian sedimentary basin was to the east or southeast. During Middle Ordovician time, a deep basin (foredeep) formed within the former Cambrian to Lower Ordovician shelf west of the uplifted area in the Piedmont. This foredeep was bordered on the west by a shallow-water Middle Ordovician carbonate shelf. Polymictic conglomerates, containing clasts from all the formations within the Cambrian to Lower Ordovician sequence, occur as turbidite deposits within graptolitic black shale of Middle Ordovician age (Kellberg and Grant, 1956; King and Ferguson, 1960). Later, as 
เ⿱丶万⿱宀⿻⺀大

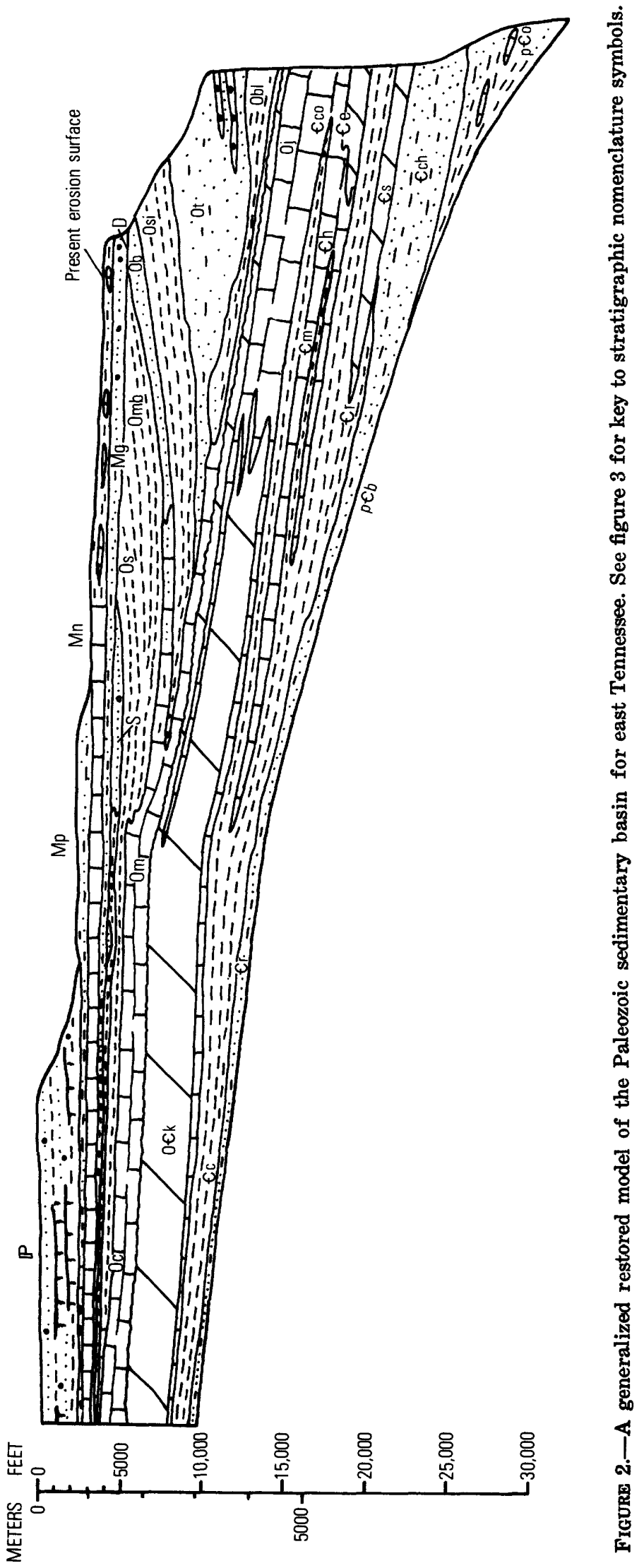


the deep basin filled, Upper Ordovician and shallowwater Silurian clastic rocks prograded westward onto the Middle Ordovician carbonate shelf. The Silurian sequence changes from an eastern beach or bar orthoquartzite sequence (Clinch Sandstone) westward into offshore shale and siltstone deposits (Rockwood Formation), which, in turn, grade into a dominantly carbonate sequence (Brassfield Formation) along the west edge of the Valley and Ridge. Apparently, sedimentation continued through part of the Lower Devonian, because there are isolated occurrences of Lower Devonian sandstone along Clinch Mountain in northeast Tennessee (Harris and Miller, 1958). Uplift and erosion prior to the deposition of the Chattanooga Shale (Upper Devonian and Lower Mississippian) removed all rock above the Middle Ordovician in the easternmost part of the Valley and Ridge and above the Silurian in the central and western parts of the Valley and Ridge.

Regionally in the Valley and Ridge, present-day erosion has removed much of the section above the Upper Devonian; consequently, reconstruction of the Late Devonian and Pennsylvanian depositional history is based on a summary of data from Tennessee and the adjacent part of southwest Virginia. The Late Devonian and Pennsylvanian sedimentary episode began with widespread deposition of Upper Devonian black shale (Chattanooga Shale). Stratigraphic data indicate that the Chattanooga is thickest $(500$ to $1,000 \mathrm{ft} ; 150$ to $300 \mathrm{~m})$ in the central part of the Valley and Ridge and that it thins both to the west $(50 \pm \mathrm{ft} ; 15 \mathrm{~m})$ and to the east (12 ft; $3.6 \mathrm{~m}$ ) (Englund, 1968; Swingle and others, 1967; Glover, 1959). In contrast, both the immediately overlying Mississippian clastic sequence (Grainger Formation) and the succeeding carbonate-shelf sequence increase in thickness rather uniformly eastward. Final filling of the southern Appalachian Paleozoic basin was accomplished by a westward advance of a series of Upper Mississippian and Pennsylvanian littoral, deltaic, and alluvial deposits (Ferm and others, 1972; Milici, 1974).

\section{TECTONIC MODEL OF THIN-SKINNED DEFORMATION}

\section{CHARACTERISTICS OF DECOLLEMENT}

The Pine Mountain thrust sheet along the common borders of Kentucky, Tennessee, and Virginia (pl. 2) is the classic model for thin-skinned defor- mation in the southern Valley and Ridge and the adjacent Appalachian Plateaus. Rich (1934), utilizing the Pine Mountain thrust as an example, suggested that deformation in the Valley and Ridge was confined to the sedimentary cover, which was stripped off crystalline basement above a detachment fault and independently deformed. Although the style of thin-skinned tectonics as outlined by Rich (1934) was widely used in interpreting the structure of the southern Valley and Ridge, for many years verification through subsurface control in the vast region was nearly nonexistent. However, in 1974, Geophysical Services, Inc., released a $20-$ mile $(32-\mathrm{km})$ segment of a migrated vibroseis profile (fig. 1) from part of the Valley and Ridge of east Tennessee. This profile clearly establishes that the thin-skinned style of deformation does characterize the structure in the southern Valley and Ridge. Major reflectors (Rome Formation, Cambrian) dip steeply southeastward from the outcrop and decrease their dip gradually in the subsurface to where they merge with the main décollement just above basement (Harris, 1976). Basement, as predicted by some earlier workers, does not seem to be involved to any great extent in the deformation process.

The general cross-sectional configuration of the décollement in the southern Appalachians (as typified by the Pine Mountain thrust sheet) consists of a lower level subhorizontal thrust in an incompetent Cambrian shaly zone on the southeast, connected with a higher level subhorizontal thrust in another incompetent shaly zone (Devonian and Mississippian) on the northwest by a moderately dipping tectonic ramp that has crosscut through a major competent zone (fig. 4). The geometry of the Pine Mountain fault, as outlined by Rich (1934), illustrates that in thin-skinned deformation, décollements are not simply low-angle shears that cut indiscriminately upward through competent and incompetent rocks; instead, their formation within a lithologic sequence is closely controlled by contrasts in rock competency. Décollements tend to form as subhorizontal features over great distances only in incompetent zones and shift abruptly upward along short diagonal ramps through more competent zones into other incompetent zones. The mechanism responsible for formation of diagonal crosscuts is thought to be either increased frictional resistance, which could not be overcome at a particular level and which required the fault to shift abruptly upward (Rich, 1934), or obstructions produced by splay thrusting, which deflect the fault upward to 
A

Parts of the Appalachian Plateau and Valley and Ridge of east Tennessee

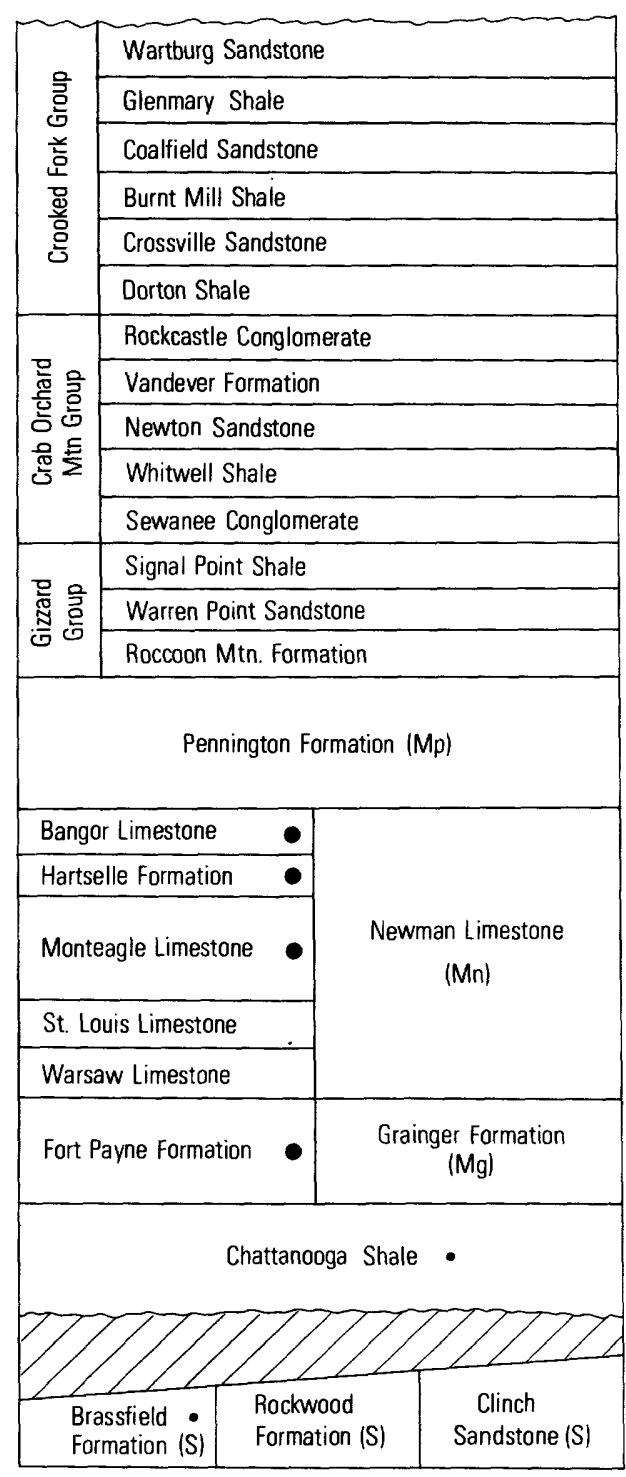

B

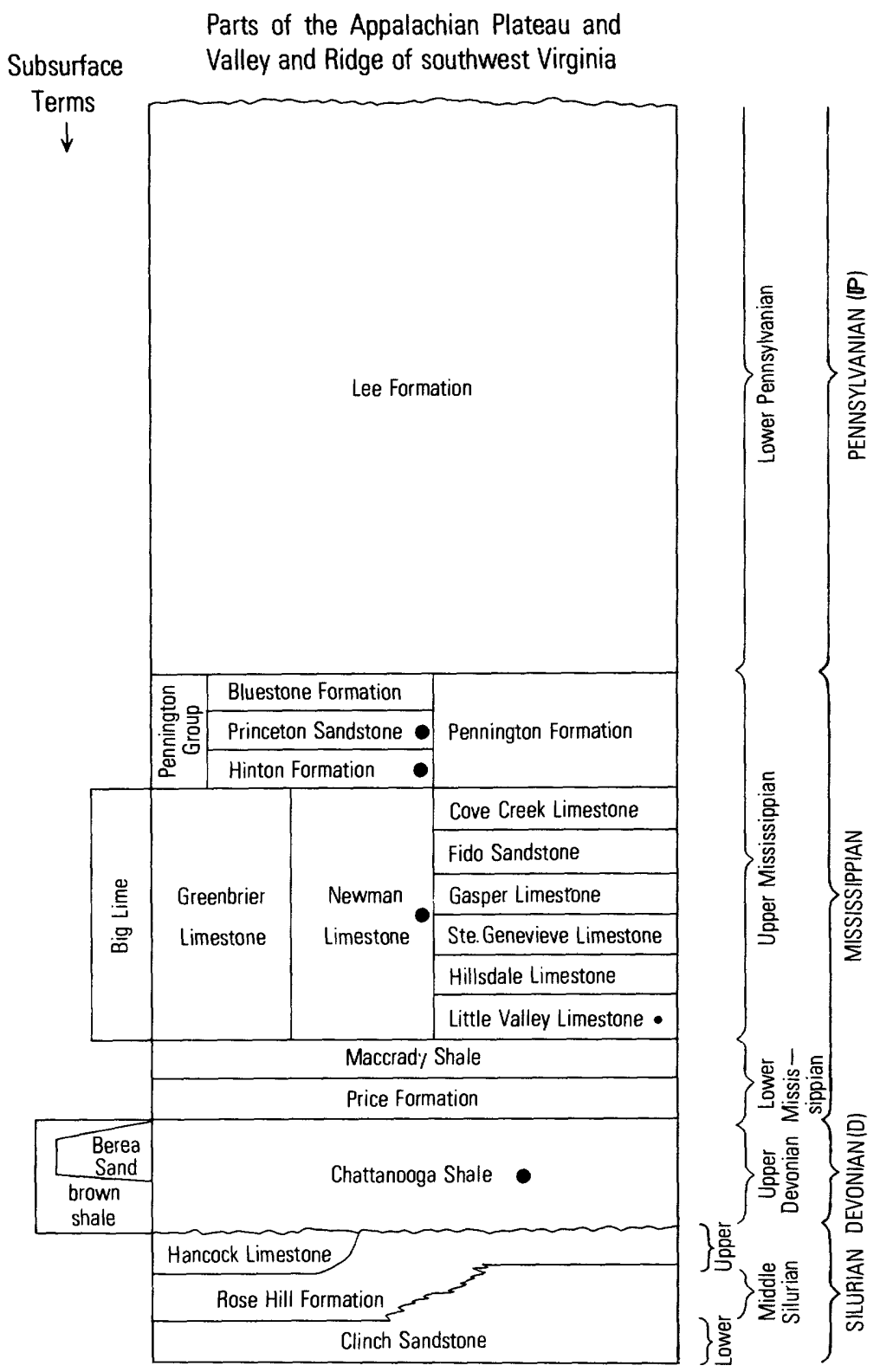

FIGURE 3.-Stratigraphic nomenclature used in parts of east Tennessee and southwest Virginia. (Letter symbols in the Tennessee column used in fig. 2 and pl. 6.) The nomenclature shown on this chart is from many sources and may or may not agree with the U.S. Geological Survey usage. Major oil-producing horizons indicated by large dot; minor producing horizons indicated by small dot.

the next younger incompetent unit or to the surface (fig. 4).

Studies of the upper level décollement (Cumberland Plateau overthrust) in the Appalachian Plateaus (Wilson and Stearns, 1958) and the lower level décollement of the Pine Mountain thrust (Harris, 1970) indicate that décollements form at different stratigraphic levels parallel to strike as well as normal to strike and unite to form an integrated system to move a thrust plate (fig. 5). Drilling and detailed mapping at the western edge of the Chest- nut Ridge fenster show that the Pine Mountain thrust changes stratigraphic position along strike toward the northeast from near the base of the Rome Formation (Lower and Middle Cambrian) along a steeply dipping transverse fault to the base of the Upper Cambrian and Lower Ordovician carbonate sequence (Harris, 1970) (fig. 6). Apparently, subsurface transverse faults act as connecting links, enabling low-angle thrust faults to form along strike at different stratigraphic levels, whereas diagonal crosscut shears commonly associated with 
A

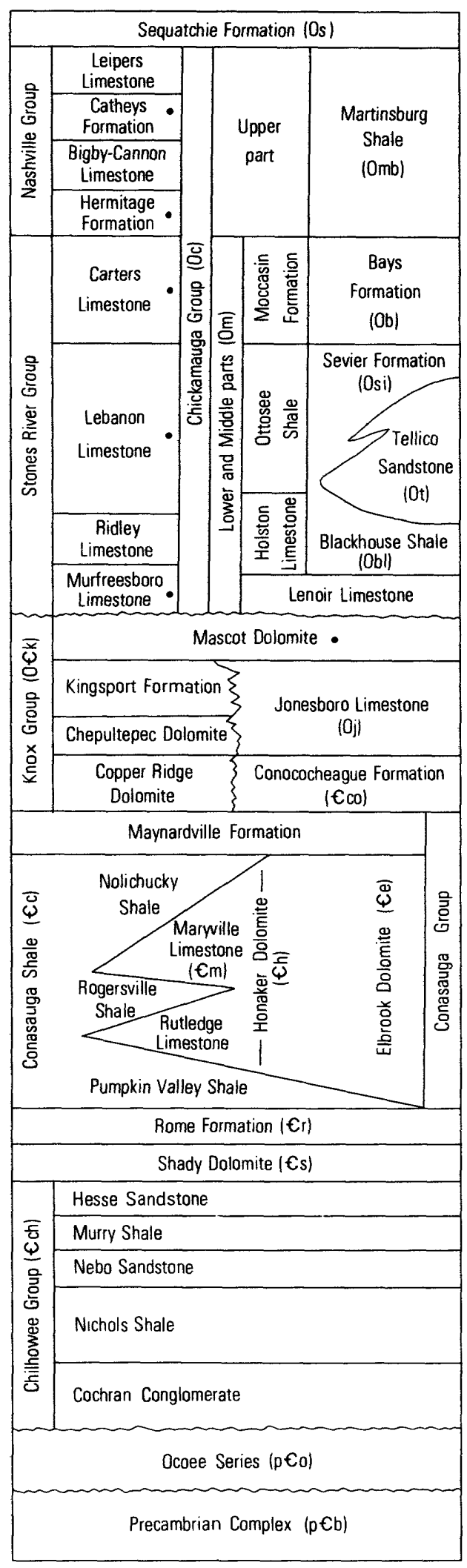

B
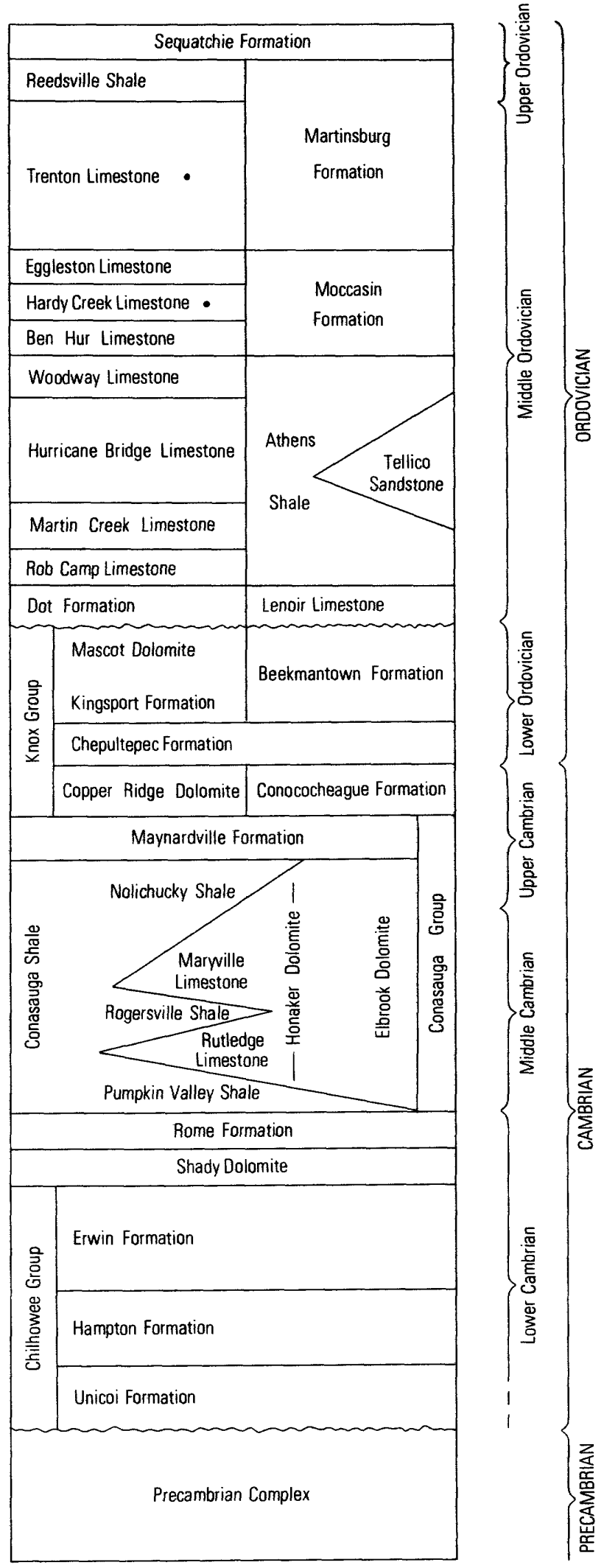

Figure 3.-Continued. 


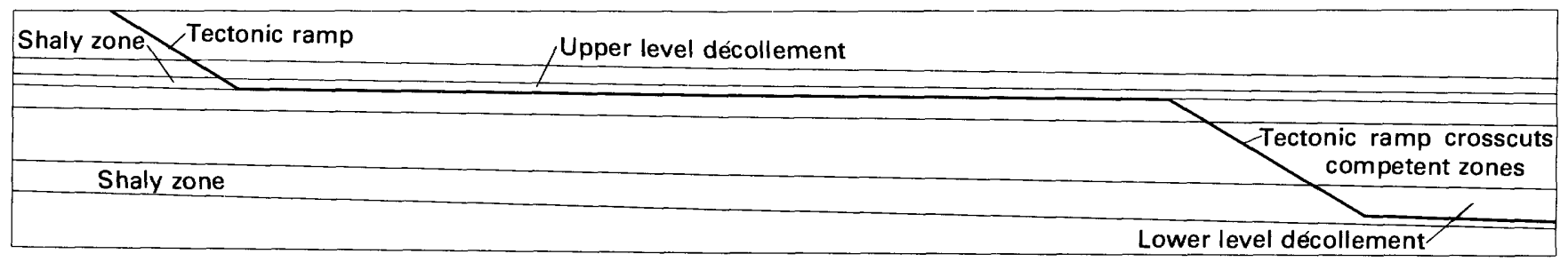

A

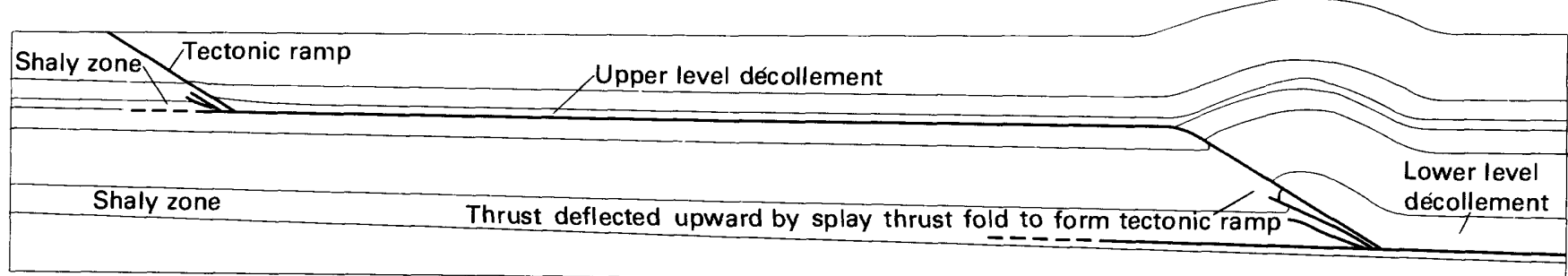

B

FIGURE 4.-Diagrammatic concepts of the initial form of a décollement system. $A$, On the basis of surface relations, Rich (1934) suggested that the Pine Mountain thrust formed as a continuous fracture that abruptly shifted from one stratigraphic level to another. $B$, Subsurface data suggest that Valley and Ridge thrusts, like the Pine Mountain, change stratigraphic levels in conjunction with the formation of splay anticlines (Harris, 1976).

splay-anticline formation are the connecting links that perform the same function perpendicular to strike.

\section{ANATOMY OF A DECOLLEMENT}

Although the gross regional geometric form of a décollement has been documented, details within the décollement zone are largely unknown because of poor or incomplete surface exposures. However, this lack of exposure has been remedied by recent road-building programs in both the Appalachian Plateaus and Valley and Ridge of east Tennessee. There massive cuts have fully exposed major parts of both the lower and upper level décollements. The upper level décollement is exposed in the Plateaus in a 2 -mile $(3.2-\mathrm{km})$ long roadcut through subhorizontal Pennsylvanian rock along Tennessee Route 8 just north of Dunlap (pl. 3). At this locality, the décollement (the Cumberland Plateau overthrust) formed under probably less than 5,000 feet $(1,500 \mathrm{~m})$ of overburden; displacement was confined to about 1,000 feet $(300 \mathrm{~m})$. The present attitude of the décollement zone near Dunlap is thought to be similar to the original attitude of that zone. In contrast, the present attitude of the décollement in the Valley and Ridge, involving the Cambrian Rome Formation above the Copper Creek thrust fault exposed in an Interstate 75 cut through Bull Run Ridge, is not the original attitude of that lower level décollement (pl. 4). At the Bull Run locality, the Copper Creek fault is exposed above a steeply dipping major tectonic ramp; thus, the dip of the décollement is simply a reflection of the dip of the underlying tectonic ramp. Displacement on the Copper Creek fault of about 10 miles $(16 \mathrm{~km})$ to the northwest has moved parts of the original subhorizontal décollement up the tectonic ramp, so that structures that formed when the décollement was subhorizontal are rotated from their original position.

Detailed studies of exposed décollement zones suggest that although upper and lower level décollements formed under major differences in overburden $(5,000 \pm \mathrm{ft}(1,500 \mathrm{~m})$ for the upper and $12,000 \pm$ ft $(3,600 \mathrm{~m})$ for the lower $)$, a single recognizable deformational pattern is common to both. This pattern was first documented at Dunlap, where it consists of a basal detachment fault overlain by deformed strata that show a distinct upward change in structural style; these strata can be divided into two zones-a lower broken-formation zone and an upper fractured zone (pls. 3 and 5). Partial confirmation that the detachment fault 

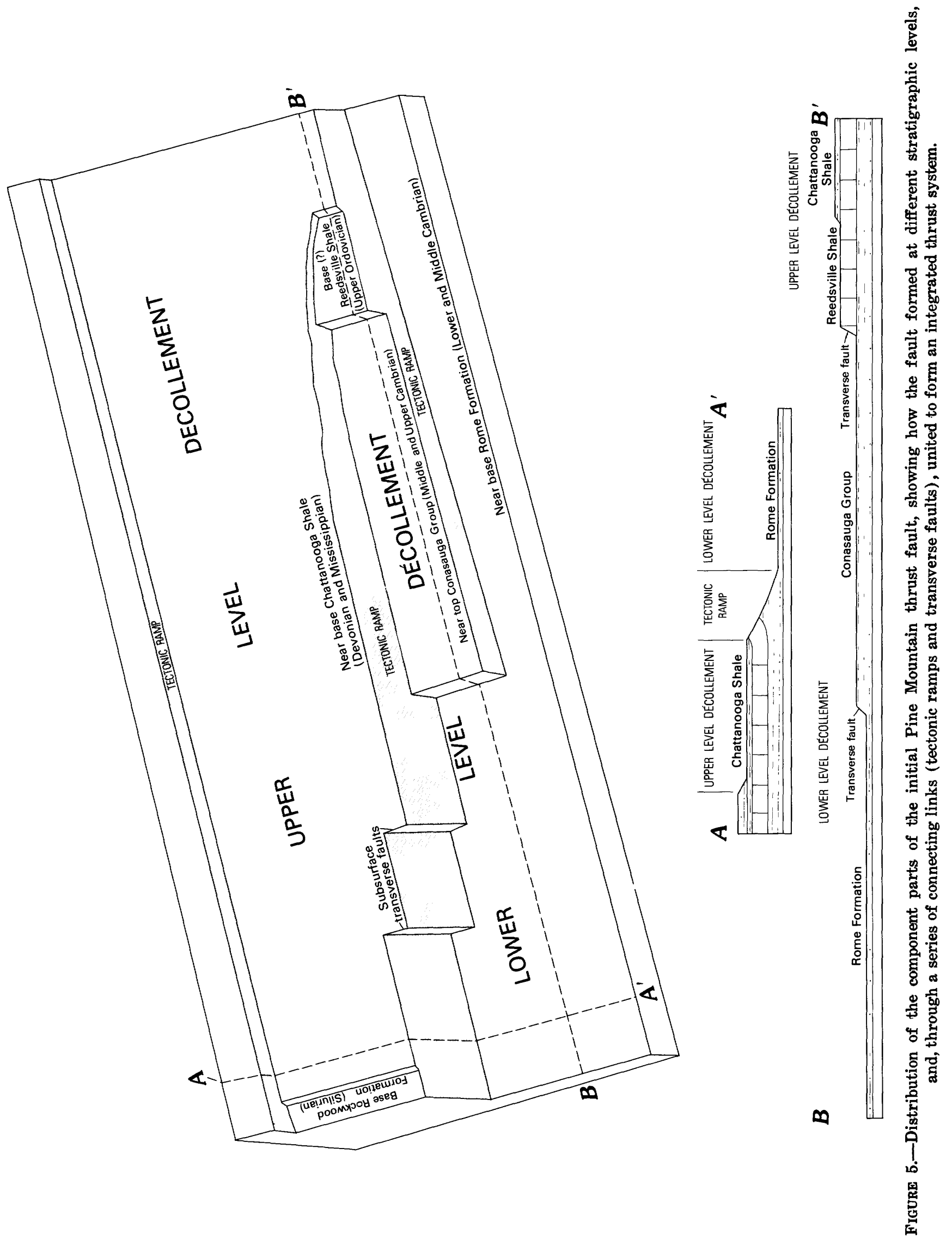


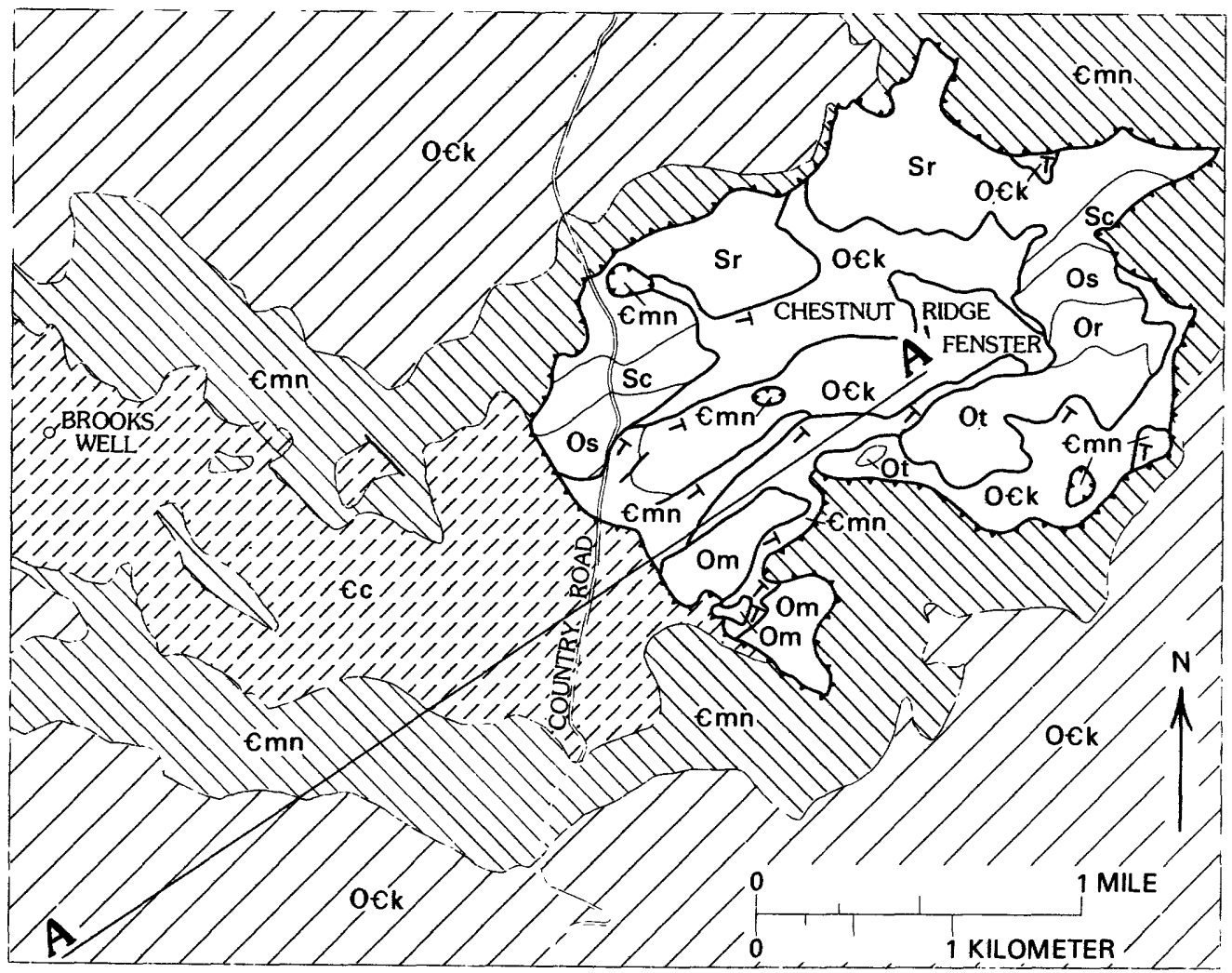

EXPLANATION

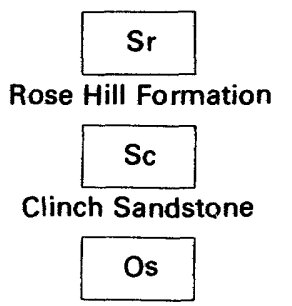

Sequatchie Formation
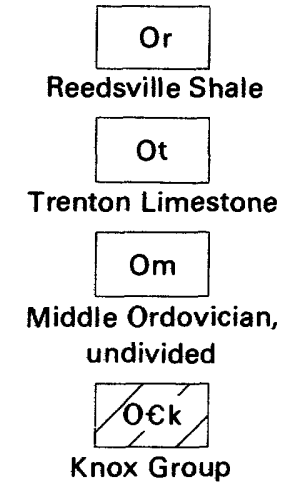

Knox Group

Ėmo

Maynardville Formation

EY, E,

\begin{tabular}{l|l|l} 
Pine Mountain thrust at base of Rome & Subsurface trans- & Pine Mountain thrust at
\end{tabular} Formation

verse fault in
hanging wall of
Pine Mountain
thrust

Conasauga Group

A
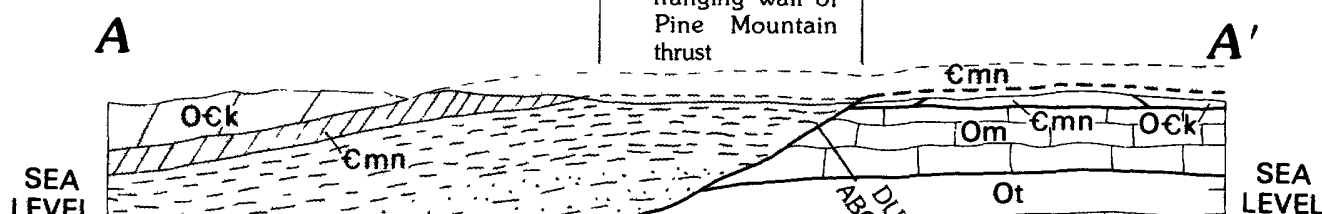
LEVEL LEVEL

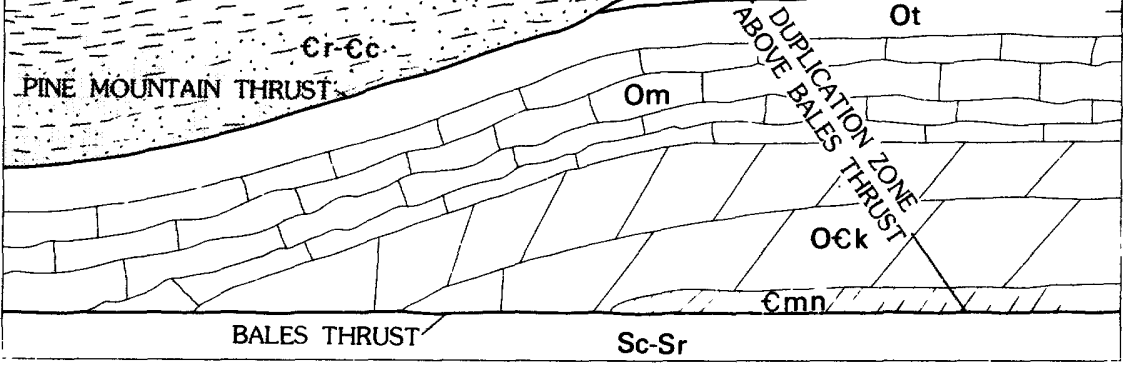

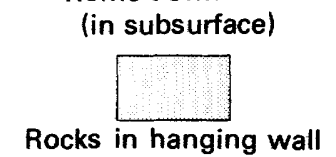

in cross section

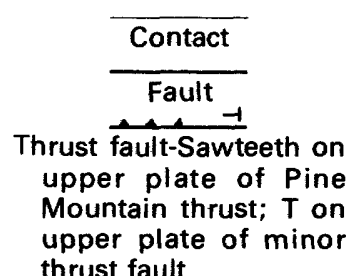

FIGURE 6.-Geologic map and structure section of the Chestnut Ridge fenster area, illustrating how the Pine Mountain thrust fault in the hanging wall initially changed stratigraphic position by a transverse fault from near the base of the Rome Formation up to the base of the Maynardville Formation. The transverse crosscut zone was later deformed by massive duplication above the subsurface Bales thrust. Hanging-wall rocks shaded and patterned in cross section and patterned on map.

formed as a bedding-plane thrust is suggested by the fact that the basal detachment parallels the top of a thin coal bed throughout the exposure of the footwall rocks. The original attitude of the detachment fault to bedding in the hanging wall could not be determined because rocks in the broken-forma- tion zone are so deformed that relationships are obscure.

The lower broken-formation zone, which overlies the detachment fault and is generally bound above by a lesser thrust fault, is composed of a series of strata that are separated into disconnected irreg- 
ularly shaped masses and elongated slabs by faults spaced from a few to about 10 feet $(3 \mathrm{~m})$ apart. Closely spaced fracturing is pervasive and is readily apparent because sandstones on exposed surfaces have a butcher-block appearance, and shales weather into small triangular or elongated tabular fragments. Subhorizontal faults and splay thrusts, rotational normal faults, and antithetic normal faults are common features in this zone. Differential movement within the décollement zone has resulted in internal distortion, so that thrust faults that are interpreted to be subhorizontal when first formed are warped and commonly offset by later faults (pl. 3).

The upper fractured zone is much less internally deformed; however, it shows a gradual upward change in structural style. The lower part of this zone is dominated by splay thrusting that has a relatively large magnitude of throw. This gives way upward to splay thrusts that have low magnitude of throw alternating laterally and vertically with areas of normal faults and normal shear faults. The upper fracture zone grades vertically into relatively undeformed strata.

Although the Dunlap structural pattern is duplicated at the Bull Run exposure in the Valley and Ridge (pls. 3 and 4), continuing regional studies of décollements demonstrate that (1) the lower broken-formation zone rarely occurs above décollements at other exposures in the Valley and Ridge; (2) more commonly, the upper fractured zone occurs above the basal detachment fault; and (3) locally, both the lower and upper zones are missing, and the relatively undeformed rocks that normally overlie the upper zone occur as the basal unit above the décollement. This regional variation in tectonic units immediately above décollements in the Valley and Ridge is related to an abandoning process that becomes operative during movement. In this process, beds immediately above the basal detachment fault apparently become intricately broken and folded as movement progresses. Obstructions forming within the broken-formation zone cause the basal detachment fault to migrate upward, abandoning the obstructed zone for a more efficient zone of movement. As a consequence, the lower-formation zone generally remains abandoned in the subsurface as higher hanging-wall beds move forward and up tectonic ramps, placing either the upper fracture zone or the overlying relatively deformed strata on younger footwall strata. The abandoning process is illustrated in figure 7, where three sections of the Rome, arranged west to east, show a progressive eastward thinning of the Rome by subtraction of material from the base of the section. In the easternmost section (3), the early stage of the final abandonment of the Rome is evident in which the incompetent shale of the Conasauga Group has begun to deform and to slide off the contact with the underlying more competent sandstone at the top of the Rome. About 4 miles $(6.4 \mathrm{~km})$ northeast along the strike of section 3, the process of abandonment of the Rome has progressed to the point that a thrust fault was mapped above the contact between the Rome and Conasauga by Cattermole (1966).

The abandonment process appears to have controlled the distribution and thickness of the Rome Formation on the surface in east Tennessee. This relationship was first noted in a seismic profile in the western part of the Valley and Ridge, where a noticeable progressive tectonic overthickening of the Rome in the subsurface from west to east is coincidental with an eastward thinning of the Rome on the surface (Harris, 1976). A correlation appears to exist between the amount of displacement on a thrust fault and the width of the outcrop belt of the Rome on the surface. Thrust faults in the western part of the Valley and Ridge have the least displacement and the most preserved Rome, whereas thrust faults to the east have the greatest displacement and the least preserved Rome (Harris, 1976; Milici, 1975).

The process of abandonment in the Valley and Ridge did not necessarily end when all the Rome was left in the subsurface. On the contrary, as displacement increased on eastern faults, all or parts of the overlying Conasauga Group may have been abandoned below the base of the overlying Knox Group (pl. 5). Thus, the thickness of the décollement abandonment zone probably continued to increase eastward as the detachment fault migrated upward and abandoned parts of the Conasauga Group.

Milici (1975) suggested that the orogenic cycle in the Valley and Ridge began with the formation of a single master décollement stretching from the Blue Ridge into the Appalachian Plateaus. Because the major detachment zone in the Valley and Ridge is near the sedimentary rock-basement contact, the earliest forming décollement apparently mimicked the geometry of the Paleozoic sedimentary basin. Reconstruction of that basin indicates that it consisted of a deep on the east bordered by a shallow shelf on the west (fig. 2). As the detachment grew, it followed the sedimentary rock-basement contact 
WEST

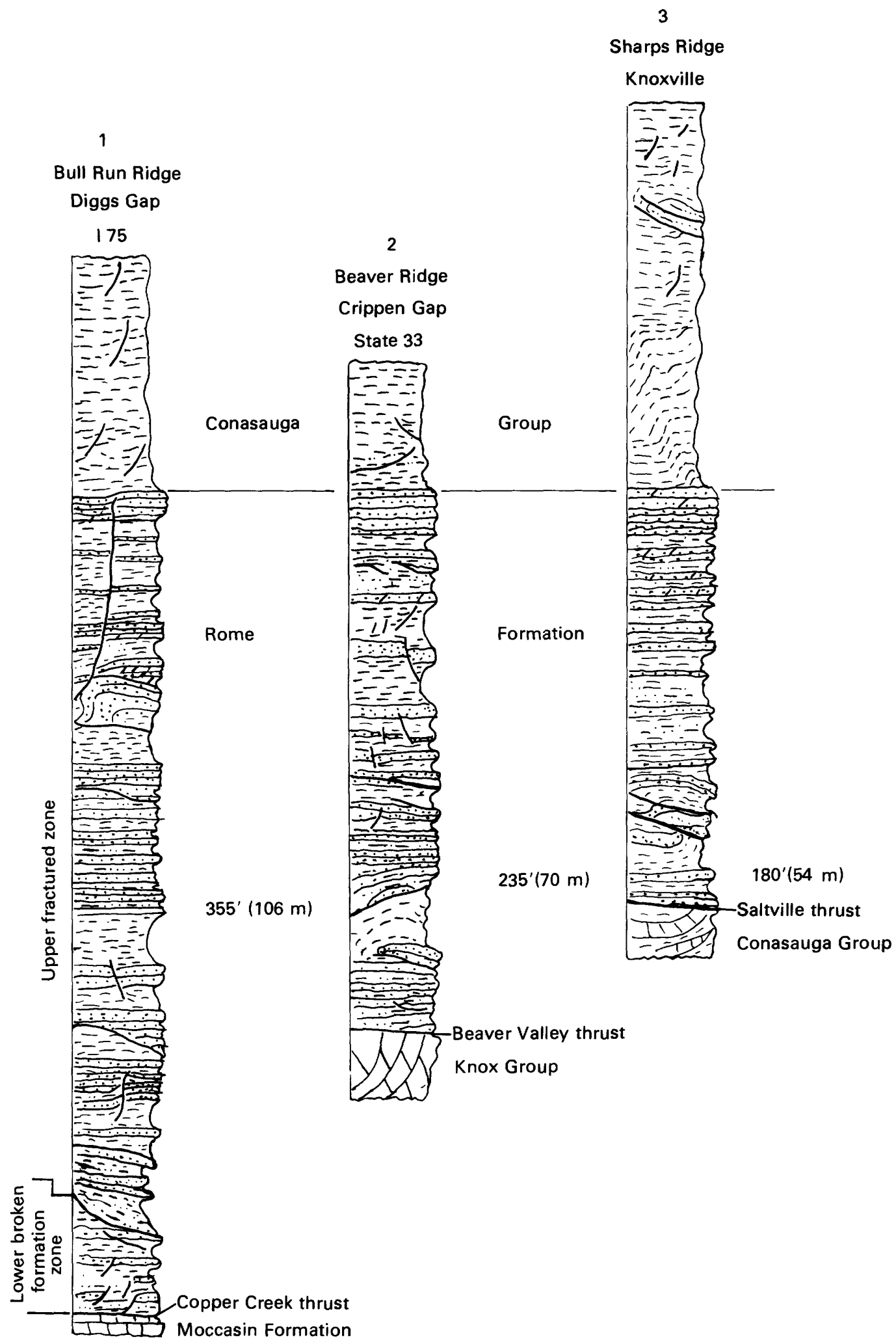

FIGURE 7.-Diagrams illustrating the progressive west-to-east tectonic thinning of the Rome Formation by subtraction of material from the base of the formation. For locations, see plate $1 A$.
EAST

Sharps Ridge

Knoxville

$==$

(a)

$1, \ldots$

$=-2$

$=-$

$=-\div-$

$\div$

Conasauga Group 
as a subhorizontal thrust through the base of the deep basin, was deflected upward by the relatively steeper slope on the west side of the deep to the edge of the shelf, where it continued as a subhorizontal detachment beneath the shelf (fig. 8). The interpreted regional form of the master décollement, before movement and modification by the abandonment process, is similar to the form of the Pine Mountain décollement except that the detachment fault has become a low-angle thrust extending into basement beneath the Blue Ridge (Harris and Milici, 1976).

\section{TYPICAL SURFIGIAL STRUCTURES}

Movement of rocks above the initial Valley and Ridge décollement produced a series of rootless anticlines and broad flat-bottomed synclines (fig. 8). Anticlines result mainly from large-scale duplication of beds as displacement moves rocks from the lower level décollements up a tectonic ramp and onto the next higher décollement surface. However, anticline formation may take place near the edge of the shelf where a thick section of Paleozoic rocks from the eastern deep is moved onto the shelf edge. Large flat-bottomed synclines are passive features that result from anticline formation.
Although surficially rootless anticlines formed by duplication of beds are similar to flexure folds formed under compression, they are actually a constructed feature confined to the allochthonous sheet (fig. 9). The most active element in the fold is the northwest limb. The crest and southeast limb inherit their attitudes from the attitude of the décollement surface in the autochthonous plate. The northwest limb is formed by a combination of uplift and transport when truncated beds ride up the tectonic ramp zone and rotate during lateral movement. Thus, a narrow-crested anticline is produced by small movement (Sequatchie anticline) or a broad flat-topped anticline by large movement (Powell Valley anticline). The manner in which rootless folds terminate is controlled either by decreasing movement along strike of a thrust or by transverse faults, some of which may cut to the surface or remain in the subsurface (fig. 5) (Harris, 1970).

The present structural pattern in the southern Valley and Ridge is dominated by thrust faults alternating with synclines (pl. 6). This pattern is far different from the original pattern of broad rootless anticlines and flat-bottomed synclines (fig. 8). Apparently the alteration of the original structural pattern was accomplished by the process of

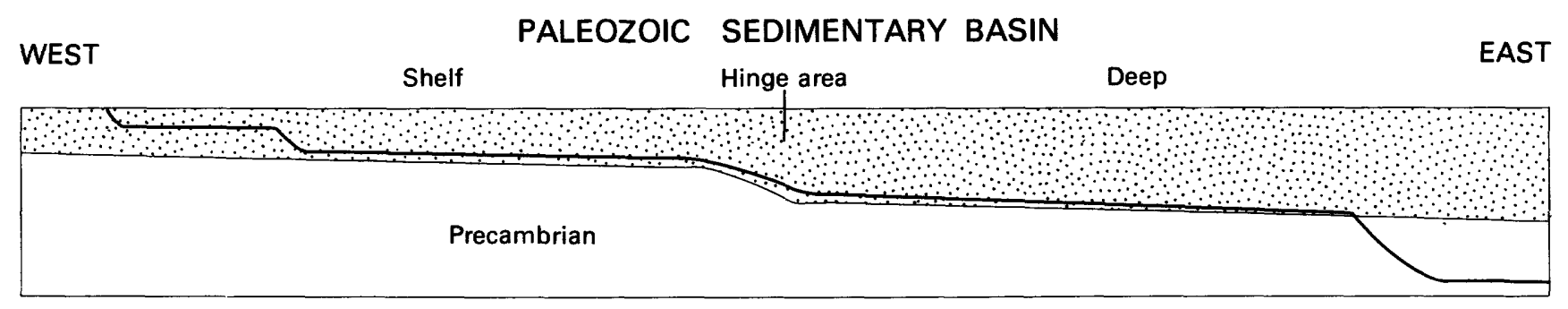

$A$

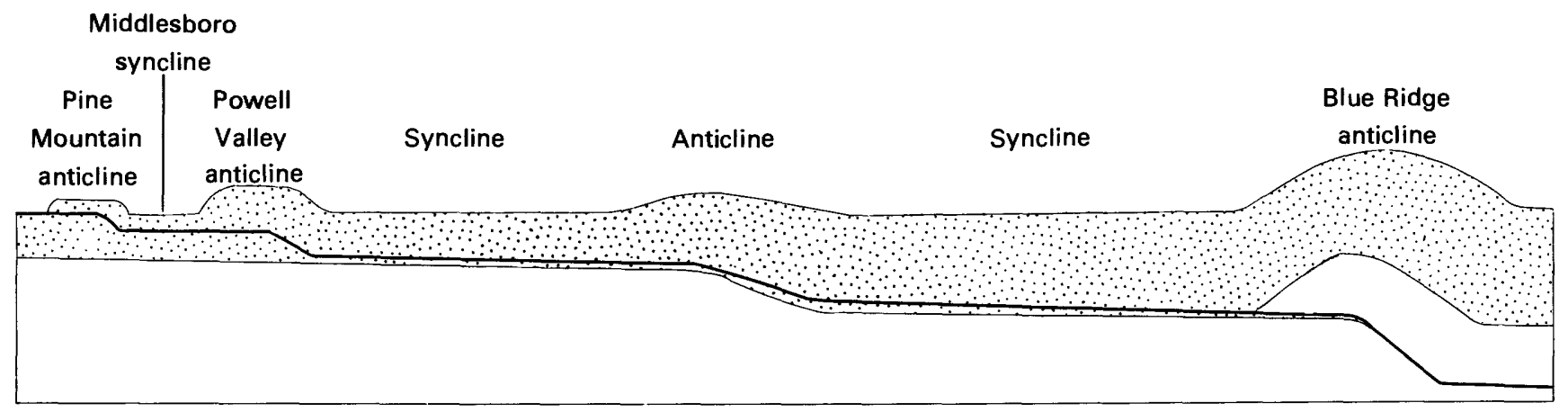

$B$

FIGURE 8.-A, The initial southern Appalachian décollement apparently formed as a low-angle thrust in basement on the east, ramped up to the basement-sedimentary rock interface, and followed that zone westward up the depositional slope of the Paleozoic sedimentary basin. $B$, En masse movement of rock up the tectonic ramps and the relatively steeper slope between the shelf and the deep resulted in the formation of a series of rootless anticlines and synclines. The amplitudes of rootless anticlines become progressively larger eastward, simply because more rock is duplicated above the detachment fault in that direction. 


\section{NORTHWEST}
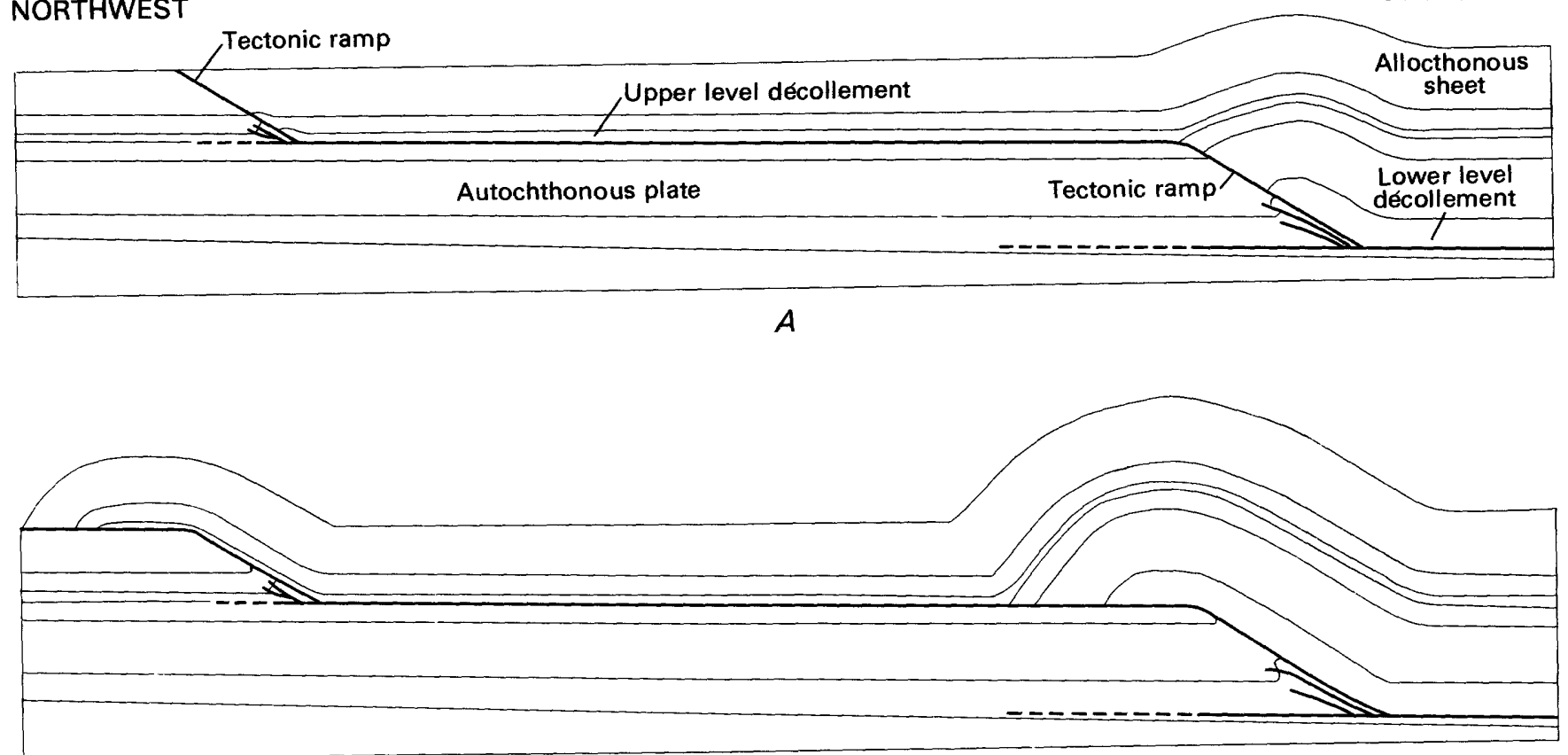

B

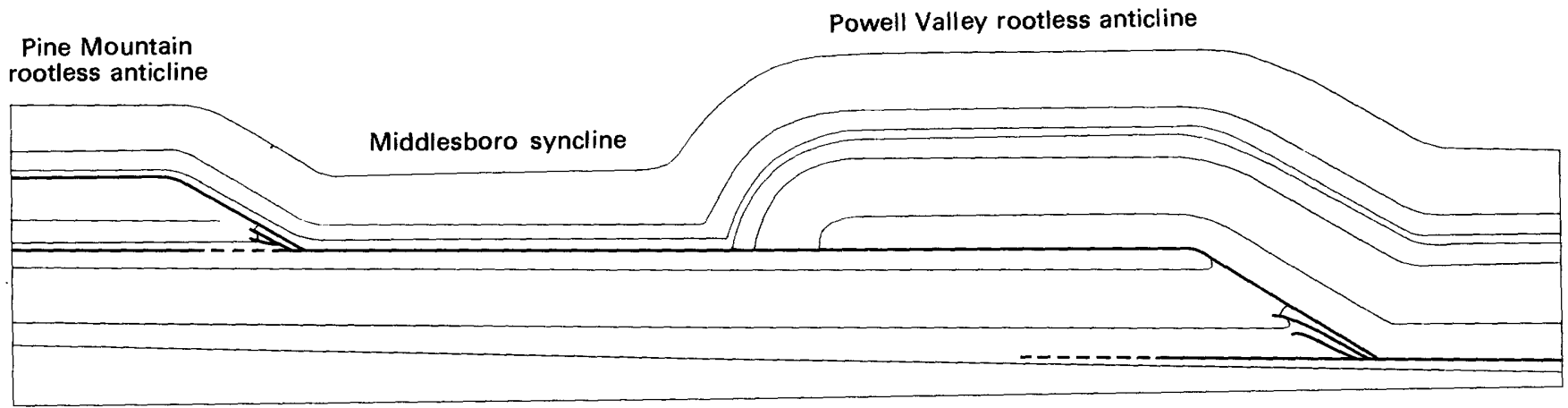

C

Figure 9.-Sequential development of the Powell Valley anticline, a surficial rootless fold typical of thin-skinned deformation. $A$, Subsurface splay thrusting in the early stages of the formation of the Pine Mountain décollement system results in the initial formation of the Powell Valley anticline. $B$, Moderate northwest movement of the allochthonous sheet causes the fold to grow by shifting the northwest limb northwestward up the tectonic ramp and rotating crosscut units onto the subhorizontal higher level décollement surface. This type of narrow-crested asymmetrical rootless anticline in which Cambrian or Ordovician rocks are exposed by erosion in the core is a common thin-skinned structure throughout parts of the Valley and Ridge and Appalachian Plateaus. $C$, Continued northwest movement enlarges the Powell Valley anticline by progressive duplication of beds above the higher level décollement. The end result is a broad rootless anticline that has an undulating crestal region, where on the surface no single axial surface defines the fold (pl. 2). Similarly, no single axial surface defines the Middlesboro syncline (Froelich, 1973) because it is a passive feature resulting from the formation of rootless anticlines on either limb.

west-to-east imbrication. This west-to-east sequential imbrication is indicated by the fact that many major thrust faults are overridden and buried from the east by the next succeeding thrust fault. For this kind of burial process to be operative throughout the southern Valley and Ridge, movement must have ceased on all overridden thrust faults in a west-to-east sequence. The imbrication process was initiated on the south limb of the Powell
Valley anticline, where the moving plate is warped over the tectonic ramp in the autochthonous plate. The obstruction forming at that point was either a splay anticline or a warp that deflected the developing imbricate upward. Because imbricates are rooted in the décollement zone, miles of movement above the imbricate has placed once-subhorizontal décollement rocks against folded footwall rocks, thereby destroying all evidence of an original fold 
and accentuating the syncline in the footwall by drag. The original anticlinal folds are evident (Saltville thrust) only to the northeast along strike of many thrust faults, where displacement on thrust faults decreases. Once the imbrication process was set in motion, the same factors that originally contributed to imbrication tended to be repeated, so that another imbricate formed on the east. In this manner, the process of imbrication shifted from west to east to produce the present structural pattern of synclines alternating with thrust faults (pl. 6).

Apparently because later forming imbricates are not stringently controlled by contrasts in rock competency as was the master décollement, imbricates commonly crosscut subhorizontally across prefolded terrane in footwalls, especially synclines, and partially or completely bury these structures (Clinchport fault in southwest Virginia; Rome fault in Georgia and Alabama; Pulaski fault in Virginia and Tennessee). It seems evident that only the initial décollement formed in relatively undeformed rocks and that all later forming imbricates originated in previously folded terrane in the later stages of the folding process (Milici, 1970; Harris, 1976).

Both the eastern and westernmost parts of the Valley and Ridge contain many fensters produced by the folding of a once-subhorizontal thrust plate. In general, thrust faults in the fenster areas form slightly asymmetrical arches, the northwest limbs being slightly steeper than the southeast flanks (fig. 10). Rocks both above and below the arched fault usually show different structural patterns; these patterns existed before folding took place. Deep drilling in the fenster area of Lee County, Va. (Bales well, 8,020 ft $(2,406 \mathrm{~m})$ total depth), indicates that arching in that area is caused by the subsurface duplication of more than 5,000 feet of rock by a nonexposed thrust fault (Harris, 1967). Another deep test (Kipps well, 9,340 ft $(2,802 \mathrm{~m}$ ) total depth) in Montgomery County, Va., drilled in the Price Mountain fenster through the Pulaski fault suggests that arching in that area is related to subsurface splay thrusting in the interval from the base of the Martinsburg Shale into the basal part of the Devonian. The mechanism that arched the Pulaski fault is similar to that described by King and Ferguson (1960) in the Mountain City fenster through the Shady Valley thrust sheet in northeast Tennessee. Apparently, duplication of Lower Cambrian rocks by a series of relatively minor imbricate thrusts in the autochthonous plate warped the Shady Valley sheet. These examples point out that "folded" thrusts are not the result of lateral com-
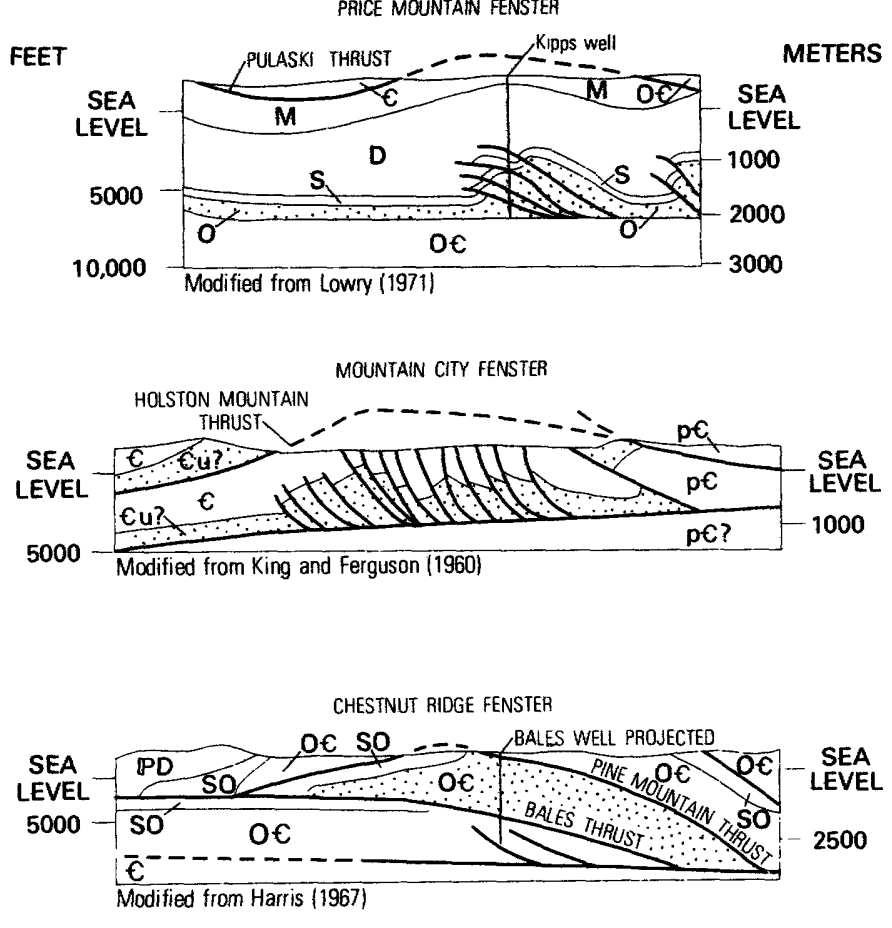

EXPLANATHN

Areas of subsurface duplication are stippled

PD, Pennsylvanian to Devonian rocks
M, Mississippian rocks
D, Devonian rocks
S, Silurian rocks
SO, Silurian and Ordovician rocks
O, Ordovician rocks
o€, Ordovician and Cambrian rocks
C, Cambrian rocks
Eu?, Unicoi Formation
p€, Precambrian rocks
p€?, Precambrian(?) rocks

FIGURE 10.-Diagrams showing essentially vertical uplift accompanying tectonic thickening in the subsurface, which is thought to be a mechanism responsible for the "folding" of thrust faults. Subsurface thickening occurs either by repetition through many minor thrusts or by massive duplication above a single thrust fault.

pression applied to both the allochthonous and autochthonous plates as a unit. Instead, arching results from subsurface duplication either as a single massive block or as a series of minor splays within the autochthonous block. Obviously, rocks of the autochthonous block are not passive elements, as suggested by Rich (1934), but take an active part in thin-skinned tectonics.

\section{OIL AND GAS PRODUCTION}

Commercial oil and gas resources are nearly confined to the flat-lying beds of the Appalachian Plateaus immediately adjacent to the Pine Mountain 
thrust fault (pl. 1, $B$ and $C$ ). However, some resources of gas do occur in Plateaus rocks in the northeast part of the Pine Mountain thrust sheet. Three relatively minor commercial hydrocarbon accumulations are within the Valley and Ridge-the Rose Hill oil field in Lee County, Va., the Early Grove gas field in Scott and Washington Counties, Va., and the Dayton oil field in Rhea County, Tenn.

Within the Appalachian Plateaus, the producing section ranges from Lower Ordovician to Pennsylvanian, principal production being obtained from Devonian and Mississippian reservoirs (fig. 3). Oil production is mainly from Mississippian reservoirs in Tennessee and that part of Kentucky just west of the Pine Mountain fault. The major gas production is from Devonian and Mississippian rocks in Kentucky that are adjacent to and extend into the northeast end of the Pine Mountain thrust sheet of Virginia. Drilling depths range from less than 2,000 feet $(600 \mathrm{~m})$ in Tennessee to more than 5,000 feet $(1,500$ $\mathrm{m})$ in parts of eastern Kentucky and Virginia.

The principal oil-producing horizon in Tennessee is the Fort Payne Formation: some production has been obtained from the Monteagle and Bangor Limestones. Porosity in the Fort Payne is confined to zones within isolated lenses of fossiliferous limestone and in the Monteagle and Bangor to porous oolite zones that have been enhanced by fracturing (Statler, 1975). Apparently, similar reservoir and porosity conditions exist in the Mississippian rocks of Kentucky adjacent to Tennessee (McFarlan, 1943). However, toward the northeast, oil reservoirs in the Fort Payne equivalent are siltstone zones, whereas porous dolomite becomes a porosity factor in the "Big Lime" (Webb, 1972).

In the major gas-producing area of Kentucky and Virginia, reservoirs include Mississippian sandstone and siltstone zones both above and below the "Big Lime," as well as the "Big Lime" and the brown shale of Devonian and Mississippian age (Chattanooga Shale of Tennessee). Porosity in all of these units may be primary; some secondary fracturing may be present in Kentucky (Ray, 1971). In Virginia, secondary fracturing associated with the Pine Mountain thrust sheet becomes the dominant porosity (Ryan, 1974).

The now-abandoned Early Grove gas field was the only commercial gas field in the southern Valley and Ridge. The field was confined to a single anticline about 7 miles $(11.2 \mathrm{~km})$ long and about 1 mile $(1.6 \mathrm{~km})$ wide (Averitt, 1941). Incomplete drilling records suggest that the Early Grove anticline may be a small splay anticline, similar to those described by Jacobeen and Kanes (1974) in the Broadtop synclinorium. Gas production at Early Grove was probably from fractures associated with the splay thrust system in the lower part of the Little Valley Limestone of Mississippian age. During the life of the field, one well was deepened to the Chattanooga Shale and obtained minor production (Huddle and others, 1956).

Until recently, the only commercially significant oil produced in the southern Valley and Ridge was from the Rose Hill oil field in the fenster area of the Pine Mountain thrust fault in southwest Virginia. More recently, minor production has been obtained from Mississippian-age rock near Dayton, Tenn. In the Rose Hill area, oil, which is entrapped in fracture zones in the Trenton Limestone and, in one instance, in the Hardy Creek Limestone, was thought to be from the so-called stationary plate exposed in a series of fensters near the crest of the Powell Valley anticline (Miller and Fuller, 1954). However, drilling in 1964-65 by the Shell Oil Co. (Bales No. 1) just south of the fenster area determined that the so-called stationary block exposed in the fenster was actually a part of a 5,600-footthick $(1,680-\mathrm{m})$ sequence of beds of Cambrian to Silurian age duplicated in the subsurface by a nonexposed thrust fault (Harris, 1967). Thus, oil production in the Rose Hill field is confined to Middle Ordovician limestone in a wedge-shaped duplicated sequence above the so-called stationary plate, and the Trenton in the stationary plate has never been tested (pl. 2).

Early exploration, in the 1940's and 1950's, in the Rose Hill field was confined to the fensters. Later, areas adjacent to fensters were drilled with some success. Sporadic drilling has continued in this area as well as to the northeast in another series of fensters similar to those of the Rose Hill area, but without much success. According to Miller and Fuller (1954), the life of most producing wells ranges from 3 months to 2 years. However, within the Rose Hill field, a few wells have continued to produce a small amount. Total cumulative oil production to 1972 is estimated to be 281,000 barrels (bbl) (B. M. Miller, 1975).

Two wells, the Eli Brooks No. 1 and the Anthony Ely No. 1, encountered relatively large shows of gas; however, both wells have been plugged and abandoned, so that no production data are available. The Ely well, drilled along U.S. 58 about 5 miles $(8 \mathrm{~km})$ northeast of the fenster area near Hagan, Va., after passing through the Pine Mountain fault, encountered an estimated 100,000 cubic feet of gas 
a day in the Reedsville Shale (Miller and Brosgé, 1954). Although the Ely well is reported to be plugged, it has continued to flare gas. The Brooks well, drilled about $11 / 2$ miles $(2.4 \mathrm{~km})$ west of the fensters, shortly after passing through the Pine Mountain fault, penetrated a gas zone in the basal sandstone of the Silurian Hancock Dolomite. Miller and Fuller (1954) reported that this well was gauged twice, once when the gas zone was penetrated and 60 days later after it had continuously blown off. The early measurement indicated that well was producing about 225,000 cubic feet per day; the second measurement was gauged at 211,000 cubic feet per day.

Three shallow exploratory wells were drilled northeast of Dayton, Tenn., in 1922 in the Valley and Ridge, approximately 2 miles southeast of the eastern Cumberland escarpment. The wells, collared in Ordovician limestones of the Rockwood thrust sheet, penetrated the fault at 700 to 800 feet . (210 to $240 \mathrm{~m}$ ) and entered shale and limestone of Mississippian age. Shows of oil or gas have been reported from each well, and one well is reported to have produced $5 \mathrm{bbl}$ per day. In 1975, Tengo Oil Co. sited a well adjacent to the 1922 wells, drilled to the same depths, and completed a small ( $5 \mathrm{bbl} /$ day) well in an oolite zone in the upper part of the Mississippian Monteagle Limestone.

Significantly, the Tengo well has confirmed the conclusion, based on surface studies (Milici and Leamon, 1975), that relatively undisturbed younger Paleozoic strata of the Appalachian Plateaus extended eastward at shallow depths beneath the Rockwood thrust fault. Since the Tengo outpost was completed, several additional tests have been planned or drilled, but information concerning these wells is not available.

\section{OIL AND GAS POTENTIAL}

Recent studies have related color changes in conodonts-from pale amber to black-to the progressive alteration of trace amounts of organic matter within the fossil (Epstein and others, 1976). This irreversible color change is related to increased temperature, principally caused by the geothermal gradient and an increase in overburden thickness and, to a lesser degree, by duration of burial. Five distinct changes in color have been recognized, and each change is indexed to its particular fixed-carbon ratio range. These color changes, called conodont alteration indices (CAI), can be utilized to estimate the oil and gas potential of the southern Appalachians.
Because the degree of alteration of the organic matter within conodonts is related to depth of burial, more than one isograd map is needed to assess the oil and gas potential at different stratigraphic levels within the Paleozoic section. Accordingly, two maps were prepared, one of the lower part of the Paleozoic section at the Ordovician level and one higher in the section at the Mississippian level (pl. $1, B$ and $C$ ). In general, both isograd maps show major changes in overall pattern from west to east. Although CAI values progressively increase eastward, there are notable differences in the lateral continuity of trends of individual isograds in the Appalachian Plateaus versus the Valley and Ridge. In the Plateaus, where the isograd pattern is not affected by thrusting, individual trend lines are continuous, but in the Valley and Ridge, where thrusting has disrupted the regional pattern by telescoping and burial, trends of individual isograds are discontinuous. Disruption of parts of the regional isograd pattern is particularly noticeable along the leading edge of the Blue Ridge-Piedmont thrust sheet, where Valley and Ridge sedimentary rocks are clearly progressively overridden and buried from the east by metamorphic and igneous rock. The disruptive relationship of thrust faults to isograds indicates that the thermal-maturity pattern in the southern Appalachians developed before the thrusting. Thus, thrusting from the east can and does place more thermally mature strata over less thermally mature strata on the west. As a consequence, isograds on the surface of a thrust sheet do not necessarily characterize the thermal maturity of rocks in the autochthonous plate. This relationship is illustrated by the fact that autochthonous rocks exposed within fensters through the Blue Ridge thrust sheet in Tennessee and the Pulaski thrust sheet in Virginia are thermally less mature than those of the overlying allochthonous sheet (pl. $1 B$ ).

Epstein, Epstein, and Harris (1976) have determined experimentally that, although minor commercial oil production may be possible between CAI 2 to 2.5, major commercial production of oil is limited to areas of CAI 2 or lower. The upper limit for production of commercial quantities of gas appears to be defined by the 4.5 isograd. The distribution of the CAI 2 isograd on the Ordovician map (pl. 1B) suggests that most of the Plateaus, but only a small part of the Valley and Ridge in Tennessee and adjacent parts of Virginia, have a potential for commercial production of oil. The 4.5 isograd is restricted to the easternmost edge of the Valley and Ridge, suggesting that if suitable traps and source 
beds are available, most of the southern Valley and Ridge has a potential for commercial accumulations of gas from Ordovician and possibly from Cambrian rocks.

Lower value isograds of the Mississippian interval (pl. $1 C$ ), tend to shift eastward in relation to the Ordovician isograds because of less total overburden. As a consequence, all the Plateaus from the northeast end of the Pine Mountain thrust sheet to Alabama as well as parts of the Valley and Ridge may have potential for both oil and gas accumulation. However, although the remaining part of the Valley and Ridge is characterized by isograds below 4.5, major gas production is not expected because of limited distribution of Mississippian rock, except in the Valley and Ridge of Alabama.

\section{FUTURE OIL AND GAS POSSIBILITIES}

Most oil within Mississippian rocks in the Plateaus adjacent to the Valley and Ridge is in relatively small isolated stratigraphic traps. Exploring for small stratigraphic traps is difficult because there are few obvious surface indicators to guide an exploration program. As a consequence, the time lag is usually considerable between discovery of a new reservoir and the realization of the potential of a particular area. As has happened in the past in the oil-producing areas of Tennessee and Kentucky, when more subsurface data on distribution and entrapment controls become available, new drilling will extend older fields, and new reservoirs will be found.

In the major gas-producing area in Kentucky and Virginia adjacent to and in the Pine Mountain thrust sheet, two main types of reservoirs are foundisolated stratigraphic traps and so-called blanket reservoirs (Ray, 1971), both of which may be enhanced by fracturing. Blanket reservoirs are widespread lithologic units, such as Devonian and Mississippian brown shales and the Berea Sand, that produce gas in a wide area almost anywhere that a drill penetrates, although not necessarily in commercial quantities. Because of low porosity and permeability in these units, the common practice is to stimulate production by induced fracturing, which usually results in a long-lived but low-delivery production (Ray, 1971). Because production in Virginia is associated with natural secondary fracture porosity in the blanket reservoirs, efforts are being made to utilize the relationship between surface fracture patterns and subsurface production (Ryan, 1974) through an integrated program combining geologic mapping, remote-sensing data, and drilling.
If this innovative method is successful and surface fracture patterns within the Pine Mountain thrust fault system can be used as guides in exploration, substantial additional reserves will almost undoubtedly be added to the Virginia gas field. In addition, this exploration technique may be applied to areas within the Valley and Ridge, where thick accumulations of Ordovician, Devonian, and Mississippian shale, rich in organic matter, occur. Such exploration may result in the identification of favorable areas for exploration and the possible recovery of commercial quantities of gas in this province.

So few wells have completely penetrated the Cambrian through Ordovician section in the southern Appalachians that the sequence remains nearly unexplored. In a few isolated localities in the Appalachian Plateaus of Tennessee and Kentucky and in the Valley and Ridge of Virginia, minor production has been obtained either from the Trenton Limestone or from the top of the Knox Group (Ray, 1971; Statler, 1975; Miller and Fuller, 1954).

Although little is known concerning the hydrocarbon potential of the Cambrian and Ordovician in and adjacent to the southern Appalachians, some limited data concerning the entrapment mechanisms in the Trenton Limestone and the Knox Group are available. Reservoirs in the Trenton are thought to be the result of solution and fracture porosities associated with minor closures in the Appalachian Plateaus (Born and Burwell, 1939). Similarly, in the Valley and Ridge, oil appears to have been producd in areas of minor warping, where fracture zones within the Trenton are concentrated enough to form a commercial reservoir (Miller and Fuller, 1954). As pointed out earlier, oil in Virginia is produced from a wedge-shaped Cambrian-to-Silurian sequence duplicated above another Cambrian-toSilurian sequence in the autochthonous plate. Additional drilling has not outlined in the subsurface the areal extent of the duplicated subsurface slab; however, the presence of this slab in the subsurface is the probable cause for the arching of the Pine Mountain fault in the fenster area from Ewing to near Pennington Gap, Va., a distance of about 25 miles $(40 \mathrm{~km})$. Sections drawn by Miller and Brosgé (1954) throughout the area suggest that not only is the Pine Mountain thrust arched beneath the fenster area, it is also arched beneath the low-amplitude Sandy Ridge anticline on the south limb of the Powell Valley anticline (fig. 11). Arching beneath the Sandy Ridge anticline is probably related to subsurface duplication similar to that documented for the fenster area. Because drilling has been concen- 
trated locally in the subsurface-duplicated Cambrian-to-Silurian sequence exposed in the fensters in southwest Virginia, the full potential of the area has never been adequately tested. The presence in the subsurface beneath the northwest limb of the Powell Valley anticline of a duplicated Cambrian-toSilurian sequence above the same Cambrian to Ordovician sequence in the autochthonous plate simply doubles the opportunities to explore for hydrocarbon reservoirs in one well in the Powell Valley area.

The trapping mechanism that accounts for the minor production from the Knox Group in Tennessee and Kentucky is associated with the unconformity at the top of the sequence. Small commercial quantities of oil have been produced from erratically distributed paleoerosional highs containing solutionporosity zones. Although the erosional highs are discontinuous and difficult to locate, they are important because the conditions under which they formed were prevalent throughout the entire southern Appalachians.

Detailed studies in the Valley and Ridge have demonstrated that porosity zones in the Knox are not limited to rocks just beneath the unconformity (Harris, 1971). The controls and distribution of major solution-porosity zones in the upper part of the Knox Group are summarized as follows:
1. Solution processes associated with formation of the unconformity at the top of the Knox produced a regional paleoaquifer system.

2. Apparently because of major differences in solubility between limestone and dolomite, solution within the paleoaquifer system was confined to limestone tongues within the predominantly dolomite section. Depending on paleoregional dip, these limestone tongues may be 100 to 800 feet $(30$ to $240 \mathrm{~m}$ ) below the unconformity. Solution of limestone removed support from beneath the overlying dolomite, and extensive collapse formed regionally distributed, stratigraphically controlled breccia bodies.

3. Drilling in middle Tennessee and the adjacent parts of southern Kentucky and northern Alabama (Mellon, 1974) suggested that the same conditions that controlled the development of major solution-porosity zones in east Tennessee also existed in those areas. As a matter of record, zinc mine development in Smith County, Tenn., has encountered extensive open vuggy porosity. Some of these vugs are large enough to walk in. Evidently the Associated Oil and Gas Exploration, Inc., Sells well in Pickett County, Tenn., lost circulation when it penetrated this porosity zone at 2,200 feet

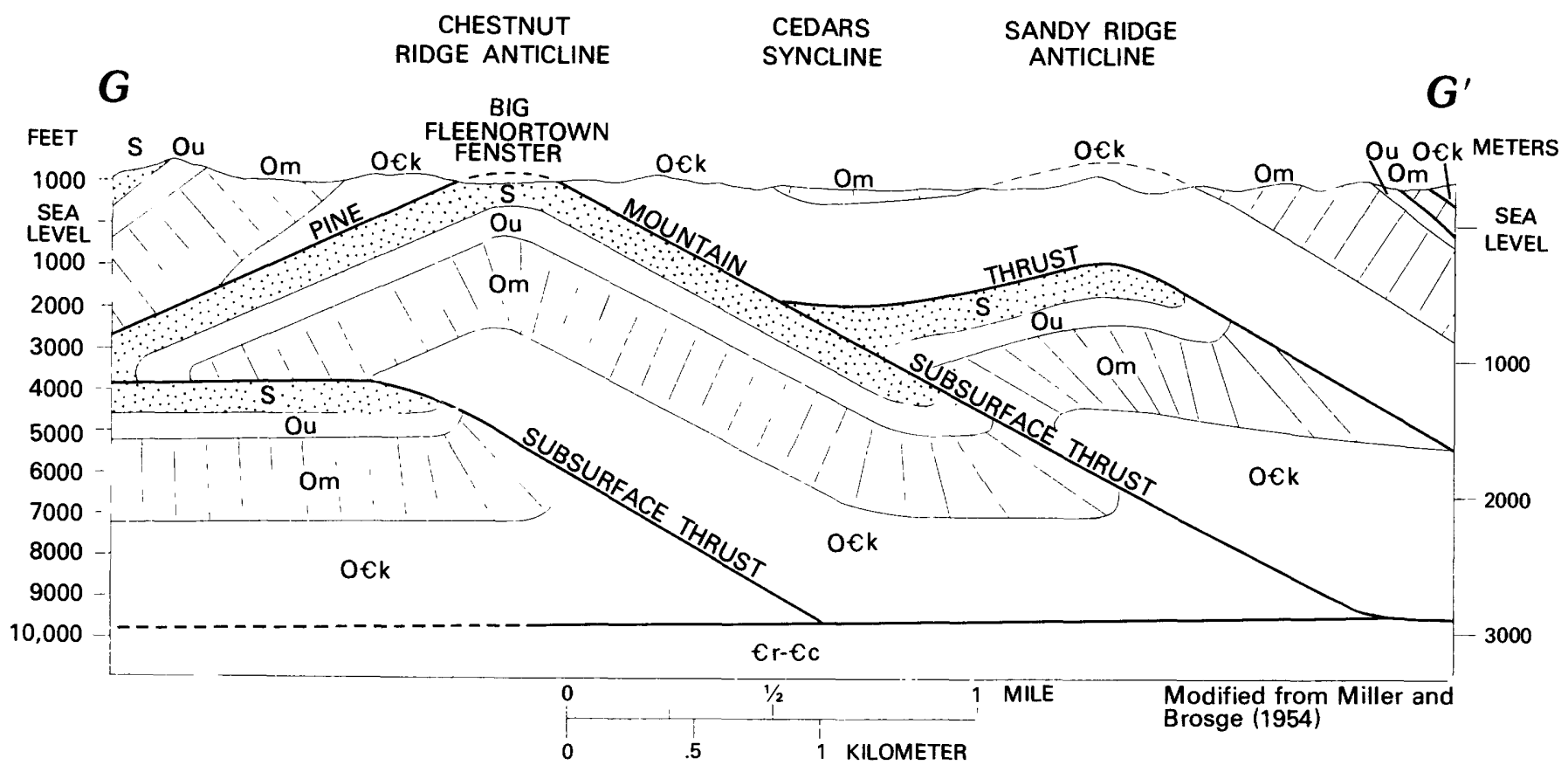

FIGURE 11.-Subsurface duplication from the autochthonous plate that has warped the Pine Mountain thrust sheet into a series of anticlines and synclines. Massive subsurface duplication provides a favorable structural setting for hydrocarbon reservoirs. Rome Formation ( $\mathbf{C r}$ ), Conasauga Group ( $\mathbf{C})$ ), Knox Group (OCk), Middle Ordovician limestone sequence $(\mathrm{Om})$, Upper Ordovician rocks $(\mathrm{Ou})$, Silurian rocks $(\mathrm{S})$. Line of section shown on plate 2. 
$(660 \mathrm{~m})$, which is about 600 feet $(180 \mathrm{~m})$ below the unconformity at the top of the Knox. Circulation was not regained until near the bottom of the hole at 4,780 feet $(1,434 \mathrm{~m})$.

Stratigraphically controlled, widely distributed, solution-porosity zones $600-800$ feet $(180-240 \mathrm{~m})$ below the unconformity at the top of the Knox offer an attractive target for exploration. However, closely spaced core holes and mining by zinc companies have demonstrated that although widespread, the upper Knox solution zones are not sheetlike. Instead, the porosity zones have a reticulate pattern, nonporous limestone intervening between master breccia conduits. Drilling for such targets would be difficult and expensive.

Published information concerning subsurface structure relative to basement rocks in the southern Valley and Ridge is limited to a single seismic profile in the western part of the Valley and Ridge of east Tennessee (fig. 1) (Harris, 1976). These data demonstrate that a fundamental change takes place from west to east in the thickness and character of the décollement zone. Because large slabs of the Rome Formation and Conasauga Group are progressively abandoned in the subsurface, the décollement zone thickens eastward. Some of the fault-bound abandoned masses appear to be sealed by the Conasauga part and are structurally situated so that fracture porosity zones, if present in the Rome part of these slabs, could have acted as traps for hydrocarbons migrating updip. Future gas-exploration efforts directed toward testing the potential of the décollement zone should be concentrated in the central and eastern parts of the Valley and Ridge where the possibility for thick accumulation of fault-bound masses is greatest.

Another significant feature outlined by the Tennessee seismic profile is the subsurface relationship of the Chattanooga and Rockwood thrust system, at the leading edge of the Valley and Ridge, to rocks of the Appalachian Plateaus. The sharp surface change from the more deformed rocks of the Valley and Ridge to the less deformed rocks of the Plateaus - the Allegheny structural front-is clearly a surficial feature. In the subsurface, Cambrian and Ordovician rocks of the Chattanooga thrust sheet have moved westward and buried a 4 -mile $(6.4-\mathrm{km})$ projection of Cambrian to Mississippian rocks of the Plateaus. Drilling by the Tengo Oil Co. near Dayton, Tenn., has confirmed the existence of the Plateaus projection by penetrating Mississippian strata at shallow depths beneath the Rockwood fault. Because the Chattanooga and associated thrust form a con- tinuous structural feature from the Jacksboro fault to the southern border of Tennessee (pl. 1A), we assume that a Cambrian to Mississippian projection of the Plateaus province is present beneath the entire length of the Chattanooga thrust fault, a distance of about 100 miles $(160 \mathrm{~km})$.

Minor production of $5 \mathrm{bbl} /$ day of oil from the Tengo well near Dayton in the Valley and Ridge is important because it demonstrates that little-deformed rocks of the Plateaus projecting beneath thrust sheets at the edge of the Valley and Ridge have a potential for hydrocarbon accumulation.

That thrusting of Valley and Ridge rocks over Appalachian Plateaus rocks in Tennessee is not an isolated structural feature is illustrated by the fact that the Powell Valley anticline within the Pine Mountain thrust sheet is a surficial feature above a projection of Cambrian to Silurian rocks of the Plateaus. In addition, a series of sections spanning the interface between the Plateaus and the Valley and Ridge in the northeastern segment of the southern Appalachians suggests that a similar Plateaus projection is present in that area (fig. 12). Thus, for a distance of about 340 miles $(544 \mathrm{~km})$, Valley and Ridge structures are commonly thrust over Plateaus rocks.

The dominant structure in the Appalachian Plateaus projection in Tennessee is a large splay anticline (fig. 1), whereas in the Virginia projection beneath the Powell Valley anticline, structure appears to be dominated by massive duplication associated with splay thrusting (pl. 2). Indication that subsurface duplication may be present in the Plateaus projection northeast of the Pine Mountain thrust sheet in Virginia is suggested by the local occurrence of doubly plunging anticlines (Burkes Garden and Bane). These anticlines are interpreted to be local warps in the allochthonous sheet produced by subsurface duplication similar to the duplication that warped the Pine Mountain fault below the Powell Valley anticline (Harris, 1967). The occurrence in the subsurface of splay anticlines and associated thrusting within Plateaus projections is important for the following reasons: (1) Structures of this type, where sealed, potentially may form major porosity traps; (2) on the basis of the distribution of conodont isograds (pl. 1, $B$ and $C$ ), Plateaus rocks are within the early stages of commercial gas generation and locally in the later stages of oil generation; and (3) because much of the Paleozoic section is contained within the projection, these structures are favorable sites to test several differ- 

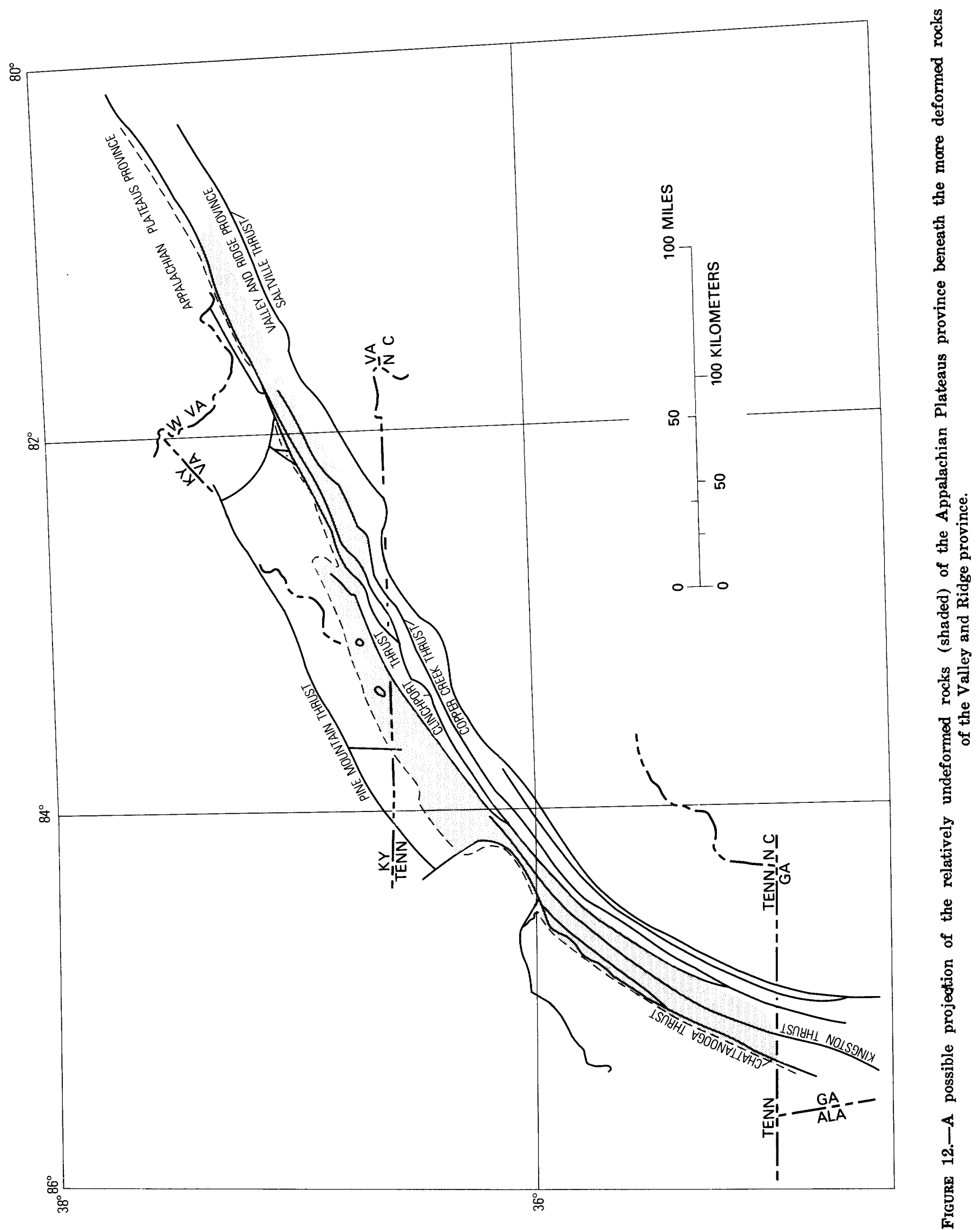
ent stratigraphic levels for potential commercial hydrocarbon accumulation.

FIELD GUIDE TO STRUCTURAL FEATURES OF THE SOUTHERN APPALACHIANS IN PARTS OF TENNESSEE AND SOUTHWEST VIRGINIA 4

Many of the general principles of thin-skinned tectonics were derived from study of the regional structural patterns in the southern Appalachians (Rich, 1934; Rodgers, 1949; King, 1960). Although the general concept of thin-skinned tectonics has long been used to explain the style of deformation in this area, only in the past several years have sufficient data become available to provide a clearer understanding of the details (Harris, 1970, 1976; Milici, 1975; Milici and Leamon, 1975). This field guide provides an opportunity to examine in the Appalachian Plateaus and the Valley and Ridge several of the classic structures previously cited as primary examples of thin-skinned deformation and to study at widely separated, well-exposed localities some of the details of this style of deformation.

The general form of a décollement in the southern Appalachians, as illustrated by the Pine Mountain thrust sheet (stops 4-7), consists on the east of a lower level subhorizontal décollement in a shaly zone near the top of the basement, connected on the west to a stratigraphically higher level subhorizontal décollement by a moderately dipping tectonic ramp (fig. 4). Décollements die out westward in the Plateaus, either in minor splays and small-scale duplication within décollement zones (Cumberland Plateau thrust) or in a single large splay anticline (Pine Mountain thrust) that deflects the fault to the surface.

A regional view of a décollement can be accomplished best by first studying the subhorizontal higher level décollement zones in the Plateaus and then proceeding to the more complexly deformed lower level décollement zones exposed above tectonic ramps in the Valley and Ridge. At two places in the Cumberland Plateau of Tennessee, one near Dunlap and the other near Ozone (stops 1 and 2), upper level décollements in subhorizontal Pennsylvanian strata are exposed in roadcuts for distances of greater than 1 mile $(1.6 \mathrm{~km})$. The exposure near Dunlap illustrates in one section the vertical tectonic zonation associated with a décollement, whereas the exposure at Ozone is an excellent example of multiple deformation dominated by minor splay thrusting in the dying-out phase of the Ozone The nomenclature shown in the road log is from many sources and
may or may not agree with the U.S. Geological Survey usage. thrust. Structures typical of the lower level décollements are illustrated in two widely separated localities within the Valley and Ridge-one along the Copper Creek fault (stop 3) in Tennessee and the other at the Hunter Valley thrust (stop 8) in southwest Virginia.

\section{ROAD LOG,}

CHATTANOOGA TO KNOXVILLE, TENN.

Chattanooga is in a topographic basin between uplands of the Cumberland Plateau to the west, Lookout Mountain on the southeast, and Missionary Ridge to the east. The Tennessee River, which has its headwaters in southwestern Virginia and western North Carolina, enters the city from the northeast (at 1.4 miles), makes its famous loop around Moccasin Bend, and leaves the Valley and Ridge to pursue a winding westward course into the Cumberland Plateau through the Walden Ridge gorge.

Chattanooga lies toward the eastern margin of the Paleozoic carbonate shelf (fig. 2), where carbonate rocks of Ordovician to Mississippian age dominate the lithologic sequence. West of Chattanooga, the Lookout Valley anticline (at 3.7 miles) forms a conspicuous linear feature along the Cumberland Plateau escarpment. The more resistant strata of Pennsylvanian sandstone and shale have been eroded along most of the length of the anticline, so that limestones as old as the Middle Ordovician (Catheys Limestone) are exposed along its axial trace. Unlike most Valley and Ridge anticlines, the Lookout Valley anticline is asymmetrical to the southeast. The field-trip route is generally toward the eastern margin of the Paleozoic carbonate shelf ; however, the route extends into the area occupied by the eastern deep basin (fig. 13).

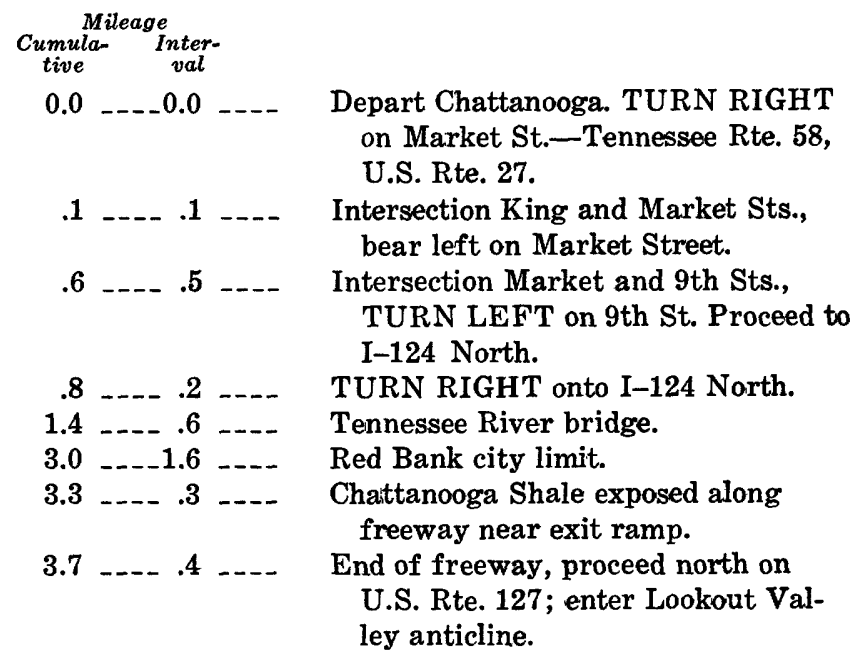

Depart Chattanooga. TURN RIGHT on Market St.-Tennessee Rte. 58, U.S. Rte. 27.

Intersection King and Market Sts., bear left on Market Street.

Intersection Market and 9th Sts., TURN LEFT on 9 th St. Proceed to I-124 North.

TURN RIGHT onto I-124 North.

Tennessee River bridge.

Red Bank city limit.

Chattanooga Shale exposed along freeway near exit ramp.

End of freeway, proceed north on U.S. Rte. 127; enter Lookout Valley anticline. 


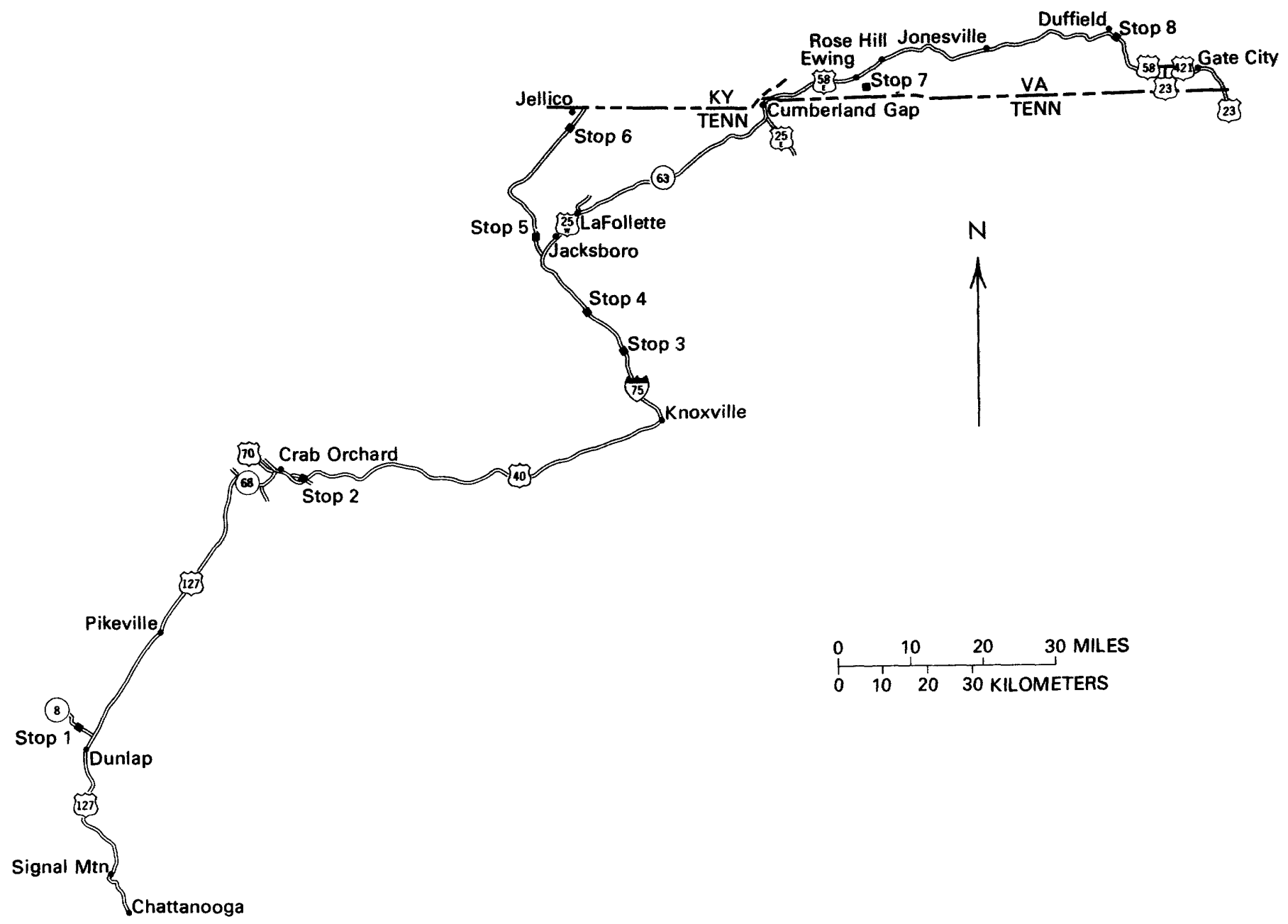

Figure 13.-Field-trip routes.

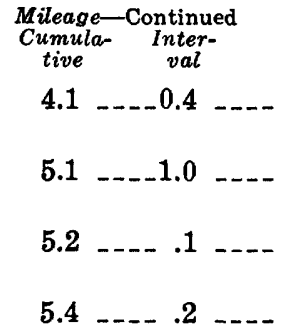

Chattanooga city limit. Rockwood Formation in cuts at right.

Northwest limb of Lookout Valley anticline.

Rockwood Formation along both sides of road.

Intersection, U.S. Rte. 127 and

Tennessee Rte. 27, proceed on U.S.

127 up Signal Mountain.

Signal Mountain Boulevard (U.S. 127) follows a winding course up the eastern Cumberland escarpment to the top of Walden Ridge at Signal Mountain. The lower levels of the escarpment are underlain by Mississippian limestones (Fort Payne Formation, Warsaw, and St. Louis Limestones, Monteagle Limestone, and Bangor Limestone), about 1,100 feet $(330 \mathrm{~m})$ thick, and the upper reaches, by shale, limestone, and sandstone (Pennington Formation and Warren Point Sandstone), about 900 feet $(270 \mathrm{~m})$ thick and having a rim rock composed of Pennsylvanian orthoquartzite. This Carboniferous sequence generally records the widespread development of the late Paleozoic carbonate shelf and its ultimate demise beneath a torrent of Pennsylvanian terrigenous clastic rocks. In the southern Cumberland Plateau of Tennessee, Upper Mississippian and Lower Pennsylvanian terrigenous clastic rocks were deposited in a series of shallow-water to littoral depositional environments (shoreface, beachbarrier, lagoon, marsh) (Ferm and others, 1972; Milici, 1974).

The Plateaus upland, underlain by Pennsylvanian strata mostly of the Gizzard and Crab Orchard Mountains Groups, is divided longitudinally into an eastern and western part by the Sequatchie anti- 
cline. The field-trip route crosses the eastern part through the northeast-plunging Walden Ridge syncline and into the Sequatchie anticline. The Walden Ridge syncline, Sequatchie anticline, and anticlinal trends along the eastern Cumberland escarpment enter Tennessee from Georgia and Alabama and extend a little more than 90 miles $(144 \mathrm{~km})$ northeast, where they are terminated by the Emory River cross fault.

\begin{tabular}{|c|c|c|}
\hline $\begin{array}{l}\text { Mileag } \\
\text { Cumulc } \\
\text { tive }\end{array}$ & $\begin{array}{c}\text { e-Continued } \\
\text { Inter- } \\
\text { val }\end{array}$ & \\
\hline 7.3 & $\ldots 1.9 \ldots$ & $\begin{array}{l}\text { Warren Point Sandstone on right; } \\
\text { Signal Mountain city limit. }\end{array}$ \\
\hline 8.3 & $\ldots 1.0 \ldots$ & Signal Point Shale. \\
\hline 8.4 & $\ldots .1$ & Sewanee Conglomerate. \\
\hline 8.5 & $\ldots . .$. & $\begin{array}{l}\text { Intersection, U.S. Rte. } 127 \text { (Signal } \\
\text { Mountain Rd.) and Palisades Dr. } \\
\text { Proceed on U.S. Rte. } 127 \text { north } \\
\text { through Signal Mountain. }\end{array}$ \\
\hline 10.0 & $\ldots 1.5 \ldots$ & $\begin{array}{l}\text { Coal rash on left, probably Richland } \\
\text { coal. }\end{array}$ \\
\hline 10.9 & $\ldots . .9 \ldots$ & Newton Sandstone left side. \\
\hline 11.2 & $\ldots . .3 \ldots$ & $\begin{array}{l}\text { Approximate base of Vandever } \\
\text { Formation. }\end{array}$ \\
\hline 11.8 & $\ldots . .$. & $\begin{array}{l}\text { Water tank, base of Needleseye } \\
\text { Conglomerate Member of Luther } \\
\text { and others (1963) of Vandever } \\
\text { Formation. }\end{array}$ \\
\hline 17.1 & $\ldots$ & $\begin{array}{l}\text { Needleseye Conglomerate Member of } \\
\text { Vandever Formation. }\end{array}$ \\
\hline 17.2 & $\ldots .1$ & $\begin{array}{l}\text { Base of Needleseye Conglomerate } \\
\text { Member of Vandever Formation. }\end{array}$ \\
\hline 17.6 & $\ldots . .4-\ldots$ & $\begin{array}{l}\text { Dip slope of Newton Sandstone on } \\
\text { southeast limb of Sequatchie anti- } \\
\text { cline. }\end{array}$ \\
\hline 18.2 & $\ldots-.6 \ldots$ & $\begin{array}{l}\text { Lower member of Vandever Forma- } \\
\text { tion caps small hill east of road. }\end{array}$ \\
\hline 18.4 & $\ldots .2 \ldots$ & Newton Sandstone. \\
\hline 19.1 & $\ldots .7 \ldots$ & Sandstone quarry, Newton Sandstone \\
\hline 19.9 & $\ldots . .8 \ldots$ & top of mountain. \\
\hline 20.8 & $\ldots . .$. & Whitewell Shale, Sewanee coal. \\
\hline 21.3 & $\ldots-.5 \quad \ldots$ & Sandstone, Sewanee Conglomerate. \\
\hline 21.8 & $\ldots .5 \ldots$ & $\begin{array}{l}\text { Contact between Sewanee Conglome- } \\
\text { rate and Signal Point Shale. }\end{array}$ \\
\hline
\end{tabular}

\section{Overlook with a view of Sequatchie anticline}

The Sequatchie anticline is a thin-skinned rootless fold formed by the rotation and duplication of beds above the westernmost major tectonic ramp in the southern Appalachians. Breached by erosion along most of its length, the Sequatchie anticline forms one of the most scenic valleys in east Tennessee. In this area, the valley floor, which is composed almost entirely of Ordovician to Mississippian carbonate strata, has been lowered to near the top of the ramp zone, exposing the Sequatchie Valley fault. Along its length, the Sequatchie Valley ramp fault rises at a moderate angle from a lower level subhorizontal décollement in Cambrian shale across a thick carbonate section that ranges from Cambrian to Mississippian in age, and, in places on the west side of the anticline, it flattens to form a subhorizontal upper level décollement in Pennsylvanian strata, the Cumberland Plateau thrust (pl. 7).

Along most of its length, the Sequatchie fault thrusts dolomite of the Knox Group or limestone of the Stones River Group over a nearly flat-lying footwall of Mississippian limestone and shale. To the northeast, along strike where erosion and displacement are less, progressively younger beds extended into the fault, and, at the head of Sequatchie Valley, the fault plunges beneath a cover of hangingwall rocks. Its extension in the subsurface probably to the Emory River cross fault was established by the Shell Oil Co.'s Peterson No. 1 (pl. 7).

The anticline has been tested for oil and gas in six places. Four of the tests were shallow, and two extended deeply into the structure. All are dry and abandoned. Five of the six tests were drilled through the Sequatchie Valley fault into flat-lying beds of the footwall and thus confirm the observation made during field mapping - that faulting took place without any prior deep-rooted folding. In contrast to structures in the Valley and Ridge where thrusts ride over folded footwalls, the Sequatchie anticline formed entirely by duplication of beds above the Sequatchie Valley fault.

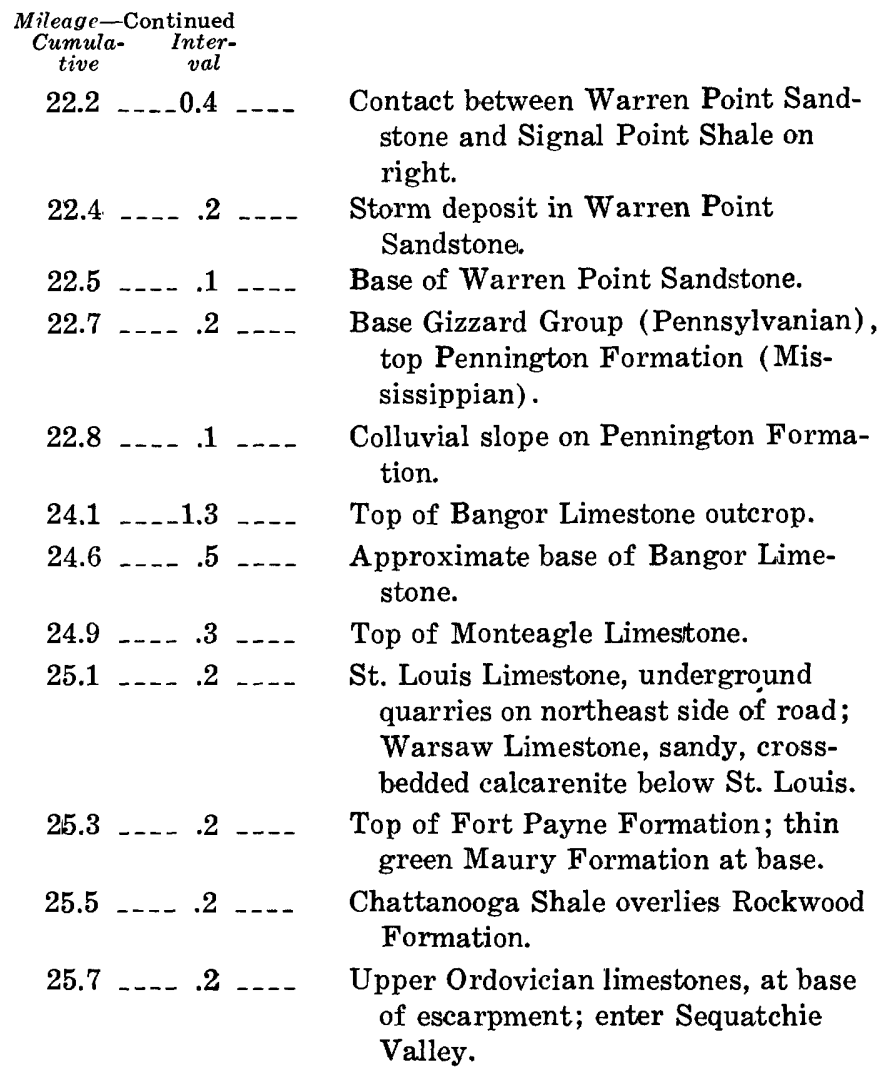




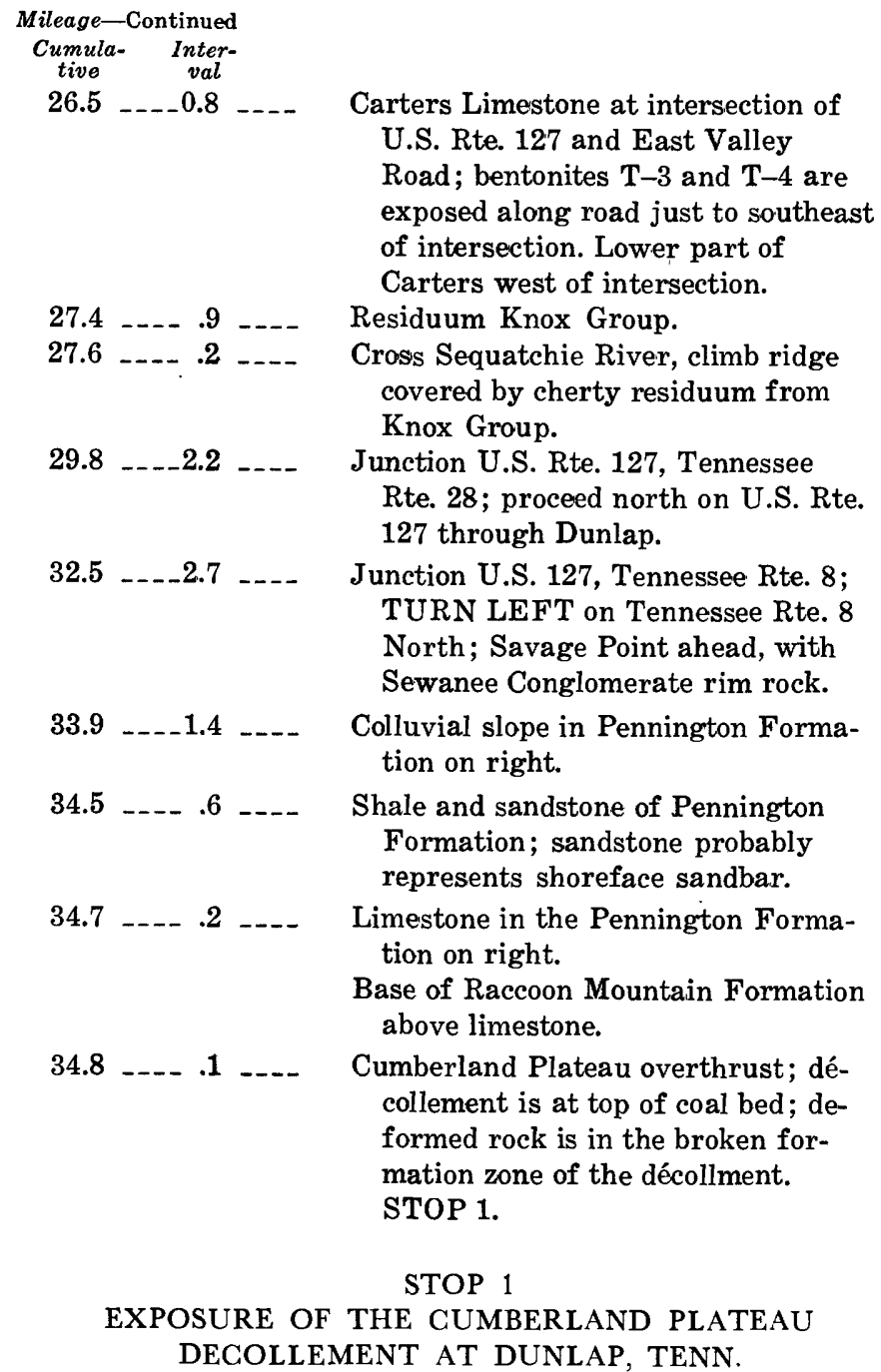

The Cumberland Plateau thrust is a décollement in Pennsylvanian rocks, which has less than a mile of northwest movement and which extended west of the Sequatchie anticline from the Emory River cross fault on the north to a little beyond Dunlap, Tenn. South of Dunlap, the Cumberland Plateau thrust is less well defined, and there is little evidence of en masse movement of hanging-wall beds in that area.

The best exposure of the Cumberland Plateau décollement zone is near Dunlap along Tennessee Rte. 8 , where the deformed zone is almost continuously exposed for a distance of 2 miles $(3.2 \mathrm{~km})$ (pl. 3$)$. At this locality, the basal detachment fault is entirely within Pennsylvanian-age rocks just above a coal bed near the base of the Raccoon Mountain Formation. However, the zone of deformation associated with the fault includes about 360 feet (108 m) of rock assigned to the Raccoon Mountain Formation, Warren Point Sandstone, Sewanee Conglomerate, and the Whitwell Shale. Strata above the
Whitwell were generally unaffected by the deformation process.

At Dunlap, the décollement zone consists of a basal detachment overlain by deformed strata which show a distinct upward change in structural style. This upward change can be divided into two zonesa lower broken-formation zone and an upper fractured zone.

That the detachment fault formed, at least in part, parallel to bedding is suggested by the fact that the fault parallels the top of a thin coal bed throughout the exposure of the footwall rocks. The lower broken-formation zone, which overlies the detachment fault and is bound above by a lesser thrust fault, is composed of intricately deformed rocks that are separated into disconnected irregularly shaped masses and elongated slabs by faults spaced a few to about 10 feet $(3 \mathrm{~m})$ apart. Differential movement within the décollement zone has resulted in internal distortion, so that thrust faults that are interpreted to have been subhorizontal when first formed have been warped as well as offset by later occurring faults. Relative ages of these detached slabs, determined where slabs override one another, suggest that they result from the abandoning process that becomes operative during movement. In the abandoning process, beds immediately above the basal detachment fault apparently become intricately broken and folded as movement progresses. Obstructions developing within the broken formation zone cause the basal detachment fault to migrate upward, abandoning the obstructed zone for a more efficient zone of movement (pl. 5).

Within the broken-formation zone, closely spaced fracturing is pervasive and is readily apparent because standstones on exposed surfaces have a butcher-block appearance, and shales weather into small triangular or elongated tabular fragments. Subhorizontal and splay thrusts, rotational normal faults, and antithetic normal faults are common features in this zone. The last-formed faults, rotational normal faults, offset all earlier formed structures for distances ranging from less than 1 foot $(0.3 \mathrm{~m})$ to about 10 feet $(3 \mathrm{~m})$. These faults apparently formed after the hanging-wall movement had ceased during a period of minor internal adjustment.

The upper fractured zone, though much less internally deformed, shows a gradual upward change in structural style. Style in the lower part of this zone is dominated by splay thrusting having a relatively large magnitude of throw. This gives way upward to splay thrusts having low magnitude of throw alternating laterally and vertically with areas of 
normal and rotational normal faults. The Sewanee Conglomerate, probably the most competent unit in the upper part of the upper fractured zone, is deformed by a series of shear normal faults. Deformation is so intense within the Sewanee that the many small slip surfaces formed subparallel to the larger rotational faults give much of the unit a crushed appearance. In contrast, less competent shale and coal beds below the sequence are deformed by flowage and in places form tectonically overthickened rolls or thin dikes that cut across adjacent competent strata. Shear normal faults appear to have been formed in response to westward flowage of incompetent rock material beneath the Sewanee Conglomerate. Deformation in shale overlying the Sewanee is represented only by minor bedding thrusts and associated splays rooted in a coal bed at the base of the shale unit.

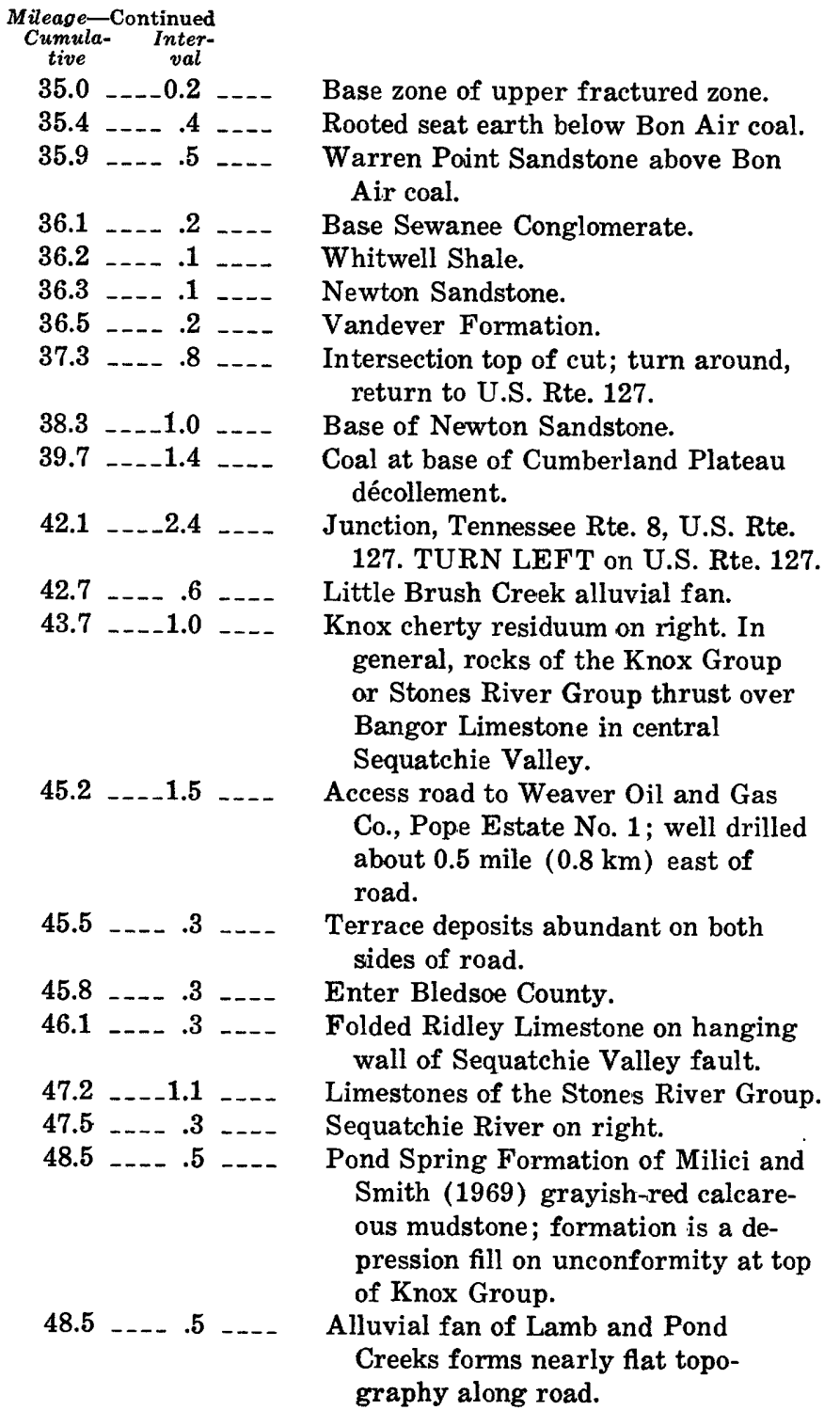

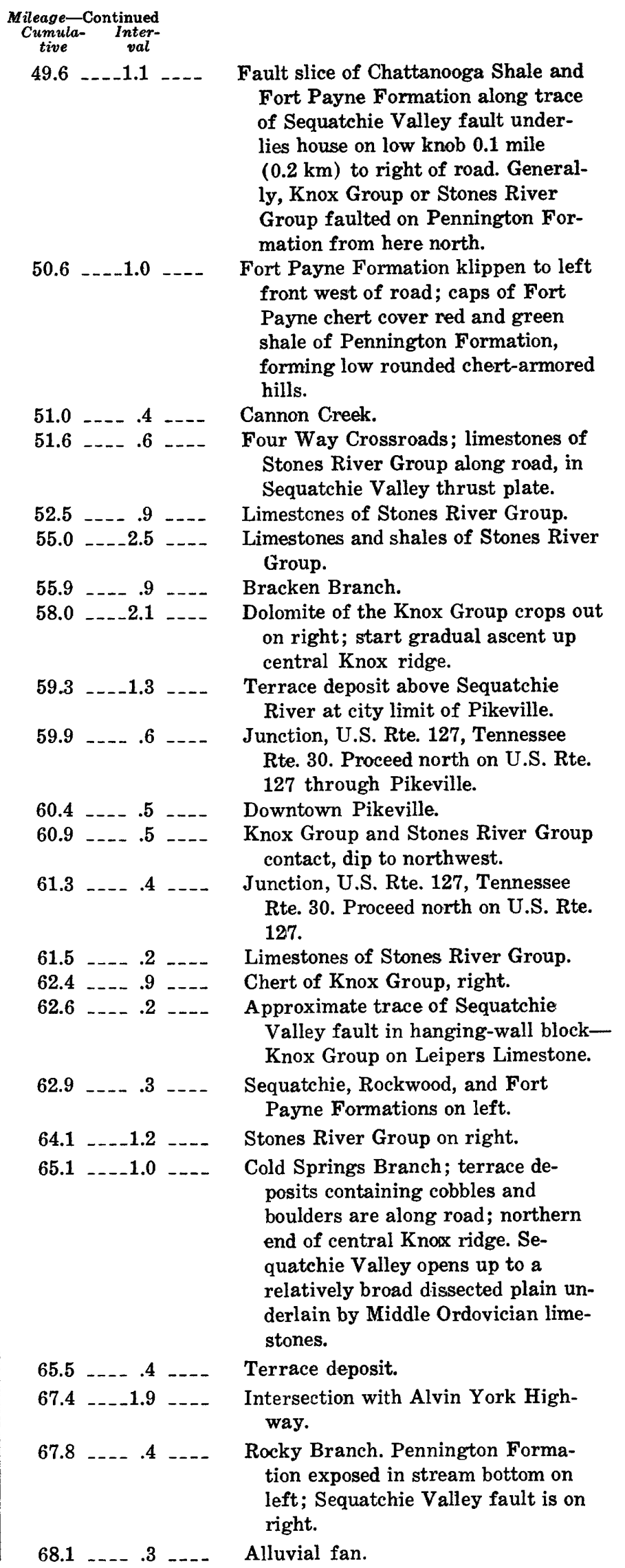




\begin{tabular}{|c|c|c|}
\hline $\begin{array}{l}\text { Mileage- } \\
\text { Cumula } \\
\quad \text { tive }\end{array}$ & 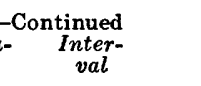 & \\
\hline 69.2 & $\ldots 1.1 \ldots$ & $\begin{array}{l}\text { Intersection; proceed north on U.S. } \\
\text { Rte. 127; Hellhole to left in Cum- } \\
\text { berland escarpment. }\end{array}$ \\
\hline 69.5 & $\ldots .-.3-\ldots$ & Terrace deposit. \\
\hline 70.7 & $-\ldots 1.2 \ldots$ & $\begin{array}{l}\text { Pennington Formation exposed along } \\
\text { base of terrace on left. }\end{array}$ \\
\hline 71.4 & $\ldots-.7 \ldots$ & $\begin{array}{l}\text { Fold in Pennington Formation on } \\
\text { left. }\end{array}$ \\
\hline 71.5 & $\ldots .1 \ldots$ & $\begin{array}{l}\text { Trace of Sequatchie Valley fault in } \\
\text { branch. }\end{array}$ \\
\hline 71.6 & $\ldots . .1 \ldots$ & $\begin{array}{l}\text { Hanging wall of Sequatchie Valley } \\
\text { fault, with Fort Payne, Chatta- } \\
\text { nooga, and Rockwood Formations. }\end{array}$ \\
\hline 71.9 & $\ldots$ & Swafford Creek. \\
\hline 73.3 & $---1.4 \ldots$ & $\begin{array}{l}\text { Folded sandstones of Pennington } \\
\text { Formation in footwall of Sequatchie } \\
\text { Valley fault on right. }\end{array}$ \\
\hline 73.6 & $\ldots$. & $\begin{array}{l}\text { Intersection with county road to } \\
\text { Litton; proceed north on U.S. Rte. } \\
127 .\end{array}$ \\
\hline 73.8 & $\ldots .2 \ldots$ & $\begin{array}{l}\text { Landslide topography above Penning- } \\
\text { ton Formation on left. }\end{array}$ \\
\hline 74.0 & $\ldots .2-\ldots$ & $\begin{array}{l}\text { Large colluvial blocks overlying Pen- } \\
\text { nington Formation on left. }\end{array}$ \\
\hline 74.6 & $\ldots .6$ & $\begin{array}{l}\text { Pennington Formation, left; shoreface } \\
\text { sandbar is interpreted as deposi- } \\
\text { tional environment (Milici, 1974); } \\
\text { hanging wall of Cumberland Plateau } \\
\text { overthrust. }\end{array}$ \\
\hline 74.8 & $\ldots .2 \ldots$ & $\begin{array}{l}\text { Top of Pennington Formation, left, } \\
\text { overlain by Gizzard lagoon-fill se- } \\
\text { quences. }\end{array}$ \\
\hline 75.0 & $\ldots .2 \ldots$ & $\begin{array}{l}\text { Sewanee Conglomerate (a beach bar- } \\
\text { rier) on left. }\end{array}$ \\
\hline 75.1 & $\ldots . .1 \ldots$ & $\begin{array}{l}\text { Whitwell Shale on left; lagoon- } \\
\text { marsh sequence. }\end{array}$ \\
\hline 75.2 & $\ldots .1 \ldots$ & $\begin{array}{l}\text { Newton Sandstone, both sides of road; } \\
\text { tidal delta. }\end{array}$ \\
\hline 75.3 & $\ldots .1 \ldots$ & $\begin{array}{l}\text { Vandever Formation, both sides of } \\
\text { road; lagoon, marsh, tidal delta se- } \\
\text { quence. }\end{array}$ \\
\hline 75.6 & $\ldots .$. & $\begin{array}{l}\text { Top of plateau, base of Rockcastle } \\
\text { Conglomerate; entrance to Cross- } \\
\text { ville limestone quarry. Quarry in } \\
\text { Mississippian Bangor Limestone. } \\
\text { Proceed across plateau toward } \\
\text { Homestead, Tenn. Crab Orchard } \\
\text { Mountains in distance on right, } \\
\text { formed by arching of resistant } \\
\text { Pennsylvanian sandstones over Se- } \\
\text { quatchie anticline. Plateau upland } \\
\text { consists of Pennsylvanian sand- } \\
\text { stones and shales of the Crab } \\
\text { Orchard Mountains and Crooked } \\
\text { Fork Groups. }\end{array}$ \\
\hline 77.8 & $---2.2-\ldots$ & Daddys Creek. \\
\hline 80.1 & $\ldots-2.3 \quad \ldots$ & Sandstone prospects. \\
\hline 83.2 & $---3.1 \quad \ldots$ & $\begin{array}{l}\text { Intersection with Alvin York High- } \\
\text { way. Proceed north on U.S. Rte. } \\
\text { 127. }\end{array}$ \\
\hline
\end{tabular}

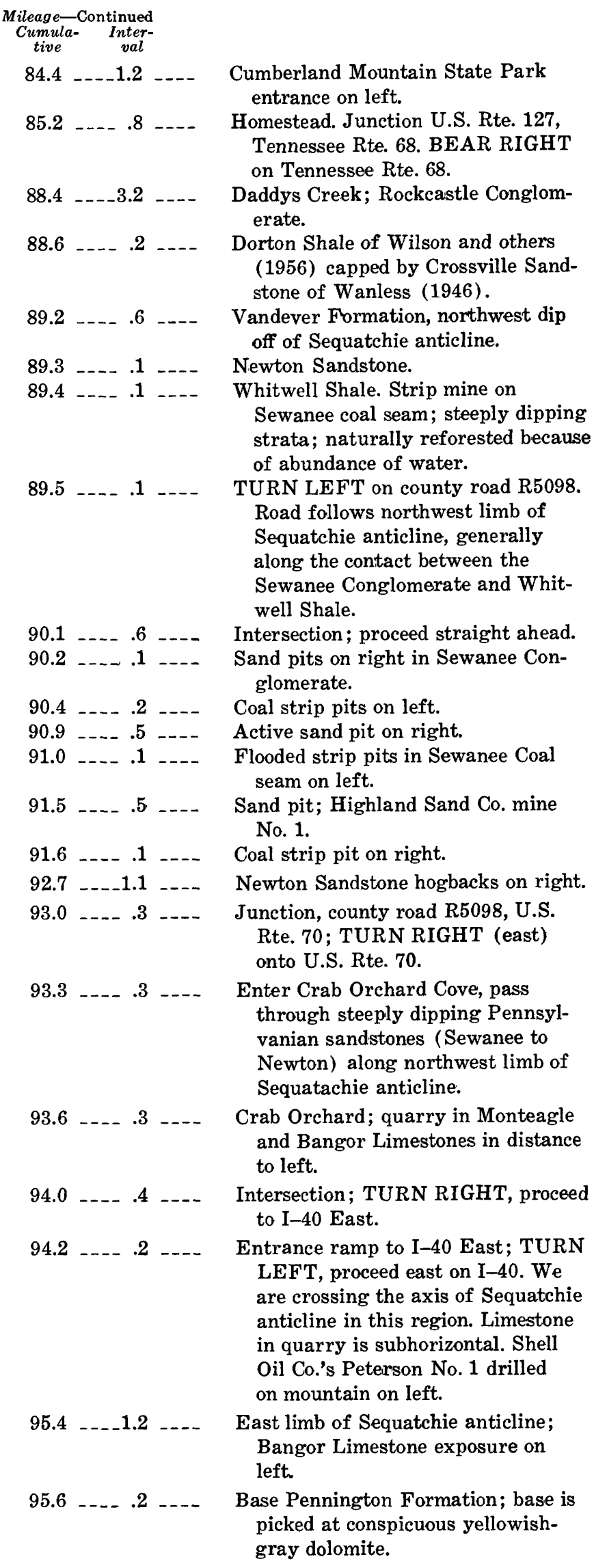

Cumberland Mountain State Park entrance on left.

Homestead. Junction U.S. Rte. 127, Tennessee Rte. 68. BEAR RIGHT on Tennessee Rte. 68.

Daddys Creek; Rockcastle Conglomerate.

Dorton Shale of Wilson and others (1956) capped by Crossville Sandstone of Wanless (1946).

Vandever Formation, northwest dip off of Sequatchie anticline.

Newton Sandstone.

Whitwell Shale. Strip mine on Sewanee coal seam; steeply dipping strata; naturally reforested because of abundance of water.

TURN LEFT on county road R5098. Road follows northwest limb of Sequatchie anticline, generally along the contact between the Sewanee Conglomerate and Whitwell Shale.

Intersection; proceed straight ahead.

Sand pits on right in Sewanee Conglomerate.

Coal strip pits on left.

Active sand pit on right.

Flooded strip pits in Sewanee Coal seam on left.

Sand pit; Highland Sand Co. mine No. 1.

Coal strip pit on right.

Newton Sandstone hogbacks on right.

Junction, county road R5098, U.S. Rte. 70; TURN RIGHT (east) onto U.S. Rte. 70.

Enter Crab Orchard Cove, pass through steeply dipping Pennsylvanian sandstones (Sewanee to Newton) along northwest limb of Sequatachie anticline.

Crab Orchard; quarry in Monteagle and Bangor Limestones in distance to left.

Intersection; TURN RIGHT, proceed to I-40 East.

Entrance ramp to I-40 East; TURN LEFT, proceed east on I-40. We are crossing the axis of Sequatchie anticline in this region. Limestone in quarry is subhorizontal. Shell Oil Co.'s Peterson No. 1 drilled on mountain on left.

East limb of Sequatchie anticline; Bangor Limestone exposure on left.

Base Pennington Formation; base is picked at conspicuous yellowishgray dolomite. 


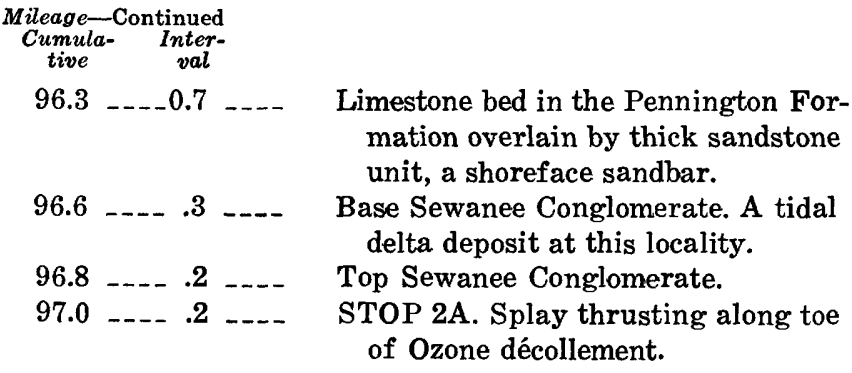

Limestone bed in the Pennington Formation overlain by thick sandstone unit, a shoreface sandbar.

Base Sewanee Conglomerate. A tidal delta deposit at this locality.

Top Sewanee Conglomerate.

STOP 2A. Splay thrusting along toe of Ozone décollement.

STOPS 2A AND 2B

AN EXAMPLE OF SPLAY THRUSTING ALONG THE TOE OF THE OZONE DECOLLEMENT

The Ozone décollement, formerly thought to be part of the Cumberland Plateau thrust system (Stearns, 1954), is the dying-out phase in the Appalachian Plateaus of a Valley and Ridge fault, the Chattanooga fault (pls. 7 and 8). The Ozone décollement follows the bedding of the Whitwell Shale from the eastern Cumberland Plateau escarpment at Rockwood to the eastern limb of the Sequatchie anticline. Displacement along the Ozone décollement is minor; however, multiple deformation within the décollement zone is sufficient to compensate for some of the displacement on the Chattanooga fault system. Near Rockwood, this compensation is evidenced by complex deformation of the Whitwell Shale and its contained Sewanee coal bed. The thickness of the Sewanee coal is normally about 4 feet $(1.2 \mathrm{~m})$; however, in an abandoned mine near Rockwood, the coal is tectonically thickened into elongated rolls, some as much as 120 feet $(36 \mathrm{~m})$ thick (Glenn, 1925). Exposures at stop 2 are typical examples of the complex development of splay thrusting involved in the multiple deformation process that distributes horizontal shortening. The Cardiff Ridge anticline, just west of stop 2 , is thought to result from multiple splay thrust, similar to stop 2, but the zone of deformation is not exposed. Like central Appalachian foreland folds, the Cardiff Ridge anticline is asymmetrical to the southeast.

The Ozone décollement, like the Cumberland Plateau décollement at Dunlap, is divisible into a lower broken-formation zone and an upper fractured zone. The position of the basal detachment fault is stratigraphically controlled and overlies a thin coal bed at the base of the Whitwell Shale. The broken-formation zone is composed of intensely fractured Whitwell Shale, from which splay thrusts of moderate displacement extend upward into the fractured zone, duplicating parts of the Whitwell, Newton, and Vandever Formations in a series of small, tightly folded thrust blocks. Thick sandstone units, where folded, are intensely crushed, whereas shale tends to be tectonically thickened in axial regions.

$\begin{gathered}\text { Mileage-Continued } \\ \text { Cumula- } \\ \text { Inter- } \\ \text { val }\end{gathered}$
$97.2 \ldots-0.2$
$97.4 \quad \ldots$
97.7
98.0

Vandever Formation, base marked by shale.

Thick shale unit in Vandever Formation; a lagoon-fill deposit.

Rippled sandstone in Vandever Formation; a distal tidal delta.

Base Rockcastle Conglomerate; dip reflects structure along east limb of Sequatchie anticline. Rockcastle is interpreted as a tidal delta but closer to a pass through the barrier than sands in Vandever Formation. Bedforms are a mixture of channel fills and sets of high-angle crossbeds.

98.6 _ 6 _._. Rockcastle Conglomerate outcrops; high-angle crossbeds.

99.8

$103.3 \ldots 3.5$ Shale on north side of interstate, probably above Rockcastle Conglomerate.

Exit 338, Westel Rd., Rockwood; leave interstate, cross over, and enter I-40 westbound; return to Ozone cuts.

109.1 110.0

110.4

110.5

$111.2 \ldots \ldots .7 \ldots$

111.4 - .2 ...112.5

$115.8 \quad \ldots--3.3 \quad \ldots-$ 122.1 _ $-\ldots 6.3$ -

123.8

$124.2 \ldots$

124.7 _... .5

124.9 _. .2 _...

125.2 -.. .3

125.4
Base Rockcastle.

STOP 2B. Splay thrusting along toe of Ozone décollement.

Whitwell Shale; décollement at coal at Whitwell and Sewanee Conglomerate contact.

Base Sewanee Conglomerate, top Gizzard Group, top Pennington Formation.

Colluvial slide in Pennington Formation on right.

Base Pennington Formation.

Exit 329, Crab Orchard, leave interstate, cross over, and enter I40 eastbound; retrace route to Westel Rd. exit.

STOP $2 \mathrm{~A}$; continue on interstate.

Exit 38, Westel Rd., Rockwood ; continue on interstate.

Crossbedded sandstone, with channelfills, coal beds; interpreted as backbarrier tidal channel, tidal delta, marsh depositional environments.

Roane County line; enter eastern time zone.

Cardiff Ridge anticline.

Northwest limb of Cumberland escarpment anticline.

Whitwell Shale and Sewanee Conglomerate, steeply dipping, are exposed along top of escarpment.

Gizzard Group and Pennington Formation exposed at gap. Gizzard is much thicker along Walden Ridge 
$\begin{array}{cc}\text { Mileage-Continued } \\ \text { Cumula- } & \text { Inter- } \\ \text { tive } & \text { val }\end{array}$

125.6

$127.7-\ldots-1.1$

$129.0 \ldots$

130.8

$131.5-\cdots .7----$

131.7

134.9

135.1 _. . 2 _...

$135.4 \ldots . . .3$

136.3

136.7 _... . 4 -..-

139.2

$139.9+\ldots .7 \ldots$

140.3

140.7 -. .4

$141.7-\ldots 1.0$

143.2

145.8

$147.7 \ldots-.9$

151.0

151.5 than at Ozone, and contains a quartz pebble conglomerate and conglomerate sandstone unit.

Landslide area along interstate.

Pennington Formation on right.

Fort Payne Formation; hanging wall of Rockwood fault; beds steeply dipping above a subhorizontal thrust; the westernmost low-angle thrust in the Valley and Ridge.

Cuts on left expose Chattanooga Shale and Rockwood Formation.

Exit 347, Harriman, Rockwood, U.S. Rte. 27; continue on interstate; cross Chattanooga fault.

Heavily wooded area along interstate contains Rome Formation and Conasauga Group.

Kingston Steam Plant on left.

Conasauga Group and Maynardville Formation exposed along U.S. Rte. 70 , to right.

Knox Group crops out on right west abutment of Clinch River bridge.

Exit 352, Tennessee Rte. 58, Kingston; continue on interstate.

Kingston fault; Conasauga Group on Knox Group.

Exit 355, Lawnville Rd.; continue on interstate; enter limestone valley in Chickamauga Group.

Clinchport fault, Rome Formation on Chickamauga Group as used by Swingle (1964). In this area, Clinchport fault marks the approximate boundary between Middle Ordovician interior platform and shelf margin facies.

Exit 356, Tennessee Rte. 58; continue on interstate. Cloverleaf in valley in Conasauga Group.

Cherty residuum of Knox Group along interstate.

Enter limestone valley in Chickamauga Group.

Interstate turns sharply to northeast and follows Conasauga valley. Ridge formed by the Rome Formation to left and ridge formed by the Knox Group to right.

Exit 360, Buttermilk Rd.

Interstate turns to southeast, climbs ridge formed by the Knox.

Exit 364, Melton Hill dam.

Enter Middle Ordovician limestone valley.

Beaver Valley fault; Rome Formation on Chickamauga Group. Junction, I-40 and I-75; BEAR LEFT, follow $\mathrm{I}-40$ and $\mathrm{I}-75$ east.

$\begin{gathered}\text { Mileage-Continued } \\ \text { Cumula- } \\ \text { tive }\end{gathered}$
$\begin{gathered}\text { Inter- } \\ \text { val }\end{gathered}$
152.9
154.1
156.8

$158.6 \ldots-.8 \ldots$ $160.0 \ldots .4$

$161.8 \ldots 1.8 \ldots$

$163.2 \ldots \ldots .4 \ldots$

$163.9 \ldots .7 \ldots$

$164.7 \ldots .8 \ldots$

$167.0 \ldots .-2.3 \ldots$

168.9 - 1.9

$170.6 \ldots$

$170.7 \ldots .1$

171.3 _- $.6 \ldots$

$171.5 \ldots .2 \ldots$

$172.0 \ldots .5 \ldots$

172.2 _- . 2 _-

$172.7 \ldots$

$173.1 \ldots .4 \ldots$

$173.4 \ldots . .$.

174.3 - .9 .9

$174.7 \ldots .4 \ldots$

$174.8 \ldots .1$

$174.9 \ldots .1 \ldots$

$175.0 \ldots .1 \ldots$

$175.4 \ldots . .4 \ldots$

176.0
Exit 369, Watt Rd. Interstate cuts diagonally across Conasauga valley.

Interstate climbs ridge formed by the Knox.

Exit 373, Campbell Station Rd.; Knox Group and Chickamauga Group contact.

Exit 374, Lovell Rd. exit.

Exit 376, Tennessee Rte. 162, Oak Ridge connector, and Mabry Hood Rd.

Exit 378, Cedar Bluff Rd; Saltville fault, Conasauga Group on Knox Group, makes a loop across interstate from near Cedar Bluff Rd. to Walker Springs Rd.

Exit 379, Walker Springs Rd. Conasauga Group, on hanging wall of Saltville fault, is along interstate.

Knoxville city limit.

Exit 380, West Hills, Residuum of Knox Group along interstate.

Exit 383, Paper Mill Rd., Bearden; contact Knox Group and Chickamauga Group.

Exit, Middlebrook Pike.

Exit 386A, 24th St., Leslie Ave.

Exit 386B, Alcoa Highway, U.S. Rte. 129.

Exit, 17th St.

Exit, U.S. Rte. 441 South Smoky Mountains, Western Ave.

Exit, I-75; TURN RIGHT, follow ramp down to I-75-North. Cloverleaf in Bays Formation (Middle Ordovician) along axis of syncline.

Exit, 5th Ave. East.

Exit, Baxter Ave., East. Cross Chickamauga Group and Knox Group contact between Baxter and Woodland Ave.

Exit, Woodland Ave.

Interstate turns left around edge of Knox ridge, then right and proceeds over wide, flat Conasauga valley.

Exit, Central Ave.

Pumpkin Valley Shale on left.

Sharps Gap; Rome Formation faulted on Knox Group along Saltville fault.

Exit, U.S. Rte. $25 \mathrm{~W}$, Clinton.

Exit, I-640; continue on I-75.

Greatly fractured Knox Group on left; Knox thrust on Chickamauga Group along Saltville fault.

Exit 25, Merchant Rd.; ChickamaugaKnox boundary at northwest side of cloverleaf. 
ROAD LOG,

KNOXVILLE, TENN., TO GUMBERLAND GAP, TENN.-VA.-KY.

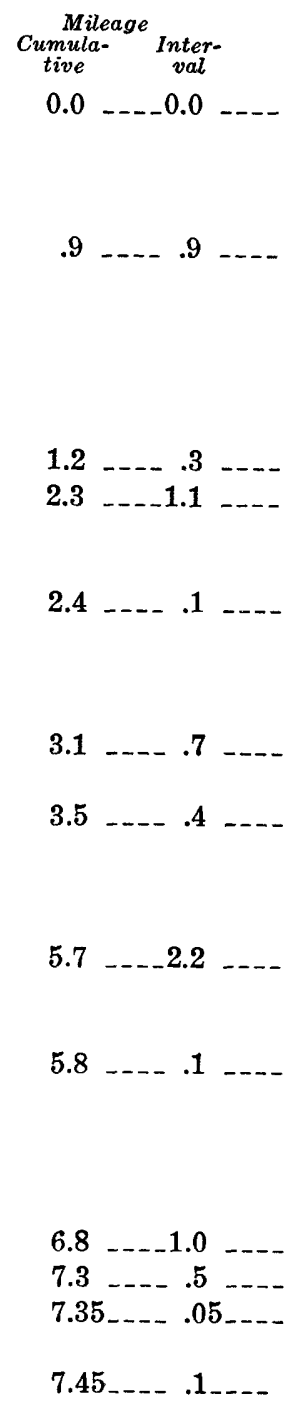

Field trip begins at intersection of I-75 and Merchant Rd., Knoxville, Tenn. (Exit 25 of I-75) at entrance to I-75 northbound (fig. 13).

Scalloped Beaver Ridge straight ahead, held up by Cambrian Rome Formation. Valley in foreground on southeast side of ridge is underlain by Conasauga Group (Middle and Upper Cambrian).

Roadcuts through Beaver Ridge.

Cross unexposed Beaver Ridge fault; field-trip route is in Copper Creek fault belt for the next 5 miles.

On right, roadcut of grayish-red, thin-bedded carbonate and calcareous mudstone of Moccasin Formation (Middle Ordovician).

Emory Rd., Exit 27, Middle Ordovician carbonate and shale valley.

Knox Group residuum in contact with Middle Ordovician. Note typical chert-rich orange soils developed on Knox Group.

On right, Maynardville Formation (Upper Cambrian), lower part limestone, upper dolomite.

Contact of Conasauga Group and Maynardville Formation. Nolichucky consists of thin limestone beds and shales, including oolite and intraclast beds.

Roadcut on left Conasauga Group.

Conasauga Group on right.

Contact between Rome Formation and overlying Conasauga Group.

Copper Creek fault. STOP 3.

STOP 3

THE LOWER LEVEL COPPER CREEK DECOLLEMENT AT BULL RUN RIDGE

At this locality, where Cambrian Rome Formation is thrust over Moccasin Formation (Middle Ordovician), the lower level Copper Creek décollement is exposed above a steeply dipping major tectonic ramp; consequently, the present attitude of the décollement is simply a reflection of the dip of the underlying ramp. Displacement of about 10 miles $(16 \mathrm{~km})$ to the northwest has moved parts of the original subhorizontal décollement up the tectonic ramp, rotating structures that were formed when the décollement was subhorizontal. Comparison of the details of the upper level Pennsylvanian décollement zone at Dunlap with the lower level Cambrian Copper Creek décollement zones (pls. 3 and 4) sug- gests that, although these zones were formed under major differences in overburden $(5,000 \mathrm{ft}(1,500 \mathrm{~m})$ versus $12,000 \mathrm{ft}(3,600 \mathrm{~m})$ ) a single deformational pattern is common to both. However, there is a major difference in footwall deformation. Both at Dunlap and at Ozone, footwall rocks are nearly undisturbed, whereas at Bull Run the footwall rocks are moderately deformed by many small splay thrusts. Splay thrusting in footwall rocks may be adjustments to compressional forces exerted by movement of the Copper Creek thrust sheet up the ramp zone.

The broken-formation zone, about 20 feet $(6 \mathrm{~m})$ thick, consists of intricately fractured sandstone, siltstone, and shale. Two minor thrust faults that are subparallel to the basal detachment fault are deformed by many rotational normal faults. The overlying zone of fracture extends upward through the Rome Formation into the base of the Conasauga Group. As in the upper fracture zone at Dunlap, compressional and tensional features occupy successive intervals through the exposure.

The exposure along the Copper Creek fault is unique because it contains the distinct upward change in structural style that characterizes the décollement zone at Dunlap. More commonly, the lower broken-formation zone is not exposed along the major tectonic ramps in east Tennessee. For example, east of the Bull Run section, the Rome Formation thins progressively so that lower parts of the Dunlap pattern are missing. The tectonic thinning of the Rome appears to be related to the development, during movement, of obstructions within the décollement zone; these obstructions caused part, and eventually all, of the Rome to be abandoned in the subsurface. This abandoning process can be demonstrated by the comparison of details in three Rome sections, arranged west to east (fig. 7). Section 1, which is the Bull Run locality, shows a complete Dunlap-type décollement zonation, but at section 2, the lower broken zone and part of the upper fracture zone are missing. In the easternmost section, more of the upper fracture zone is missing. In essence, the abandoning process resulted in a progressive west-to-east subtraction of material from the base of the Rome so that the stratigraphic position occupied by the Valley and Ridge décollement migrated vertically (pl. 5).

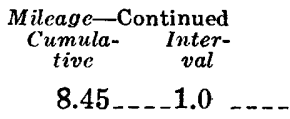

Roadcut on right exposes Middle Ordovician unconformity at the top of Lower Ordovician Mascot Dolomite of the Knox Group. 


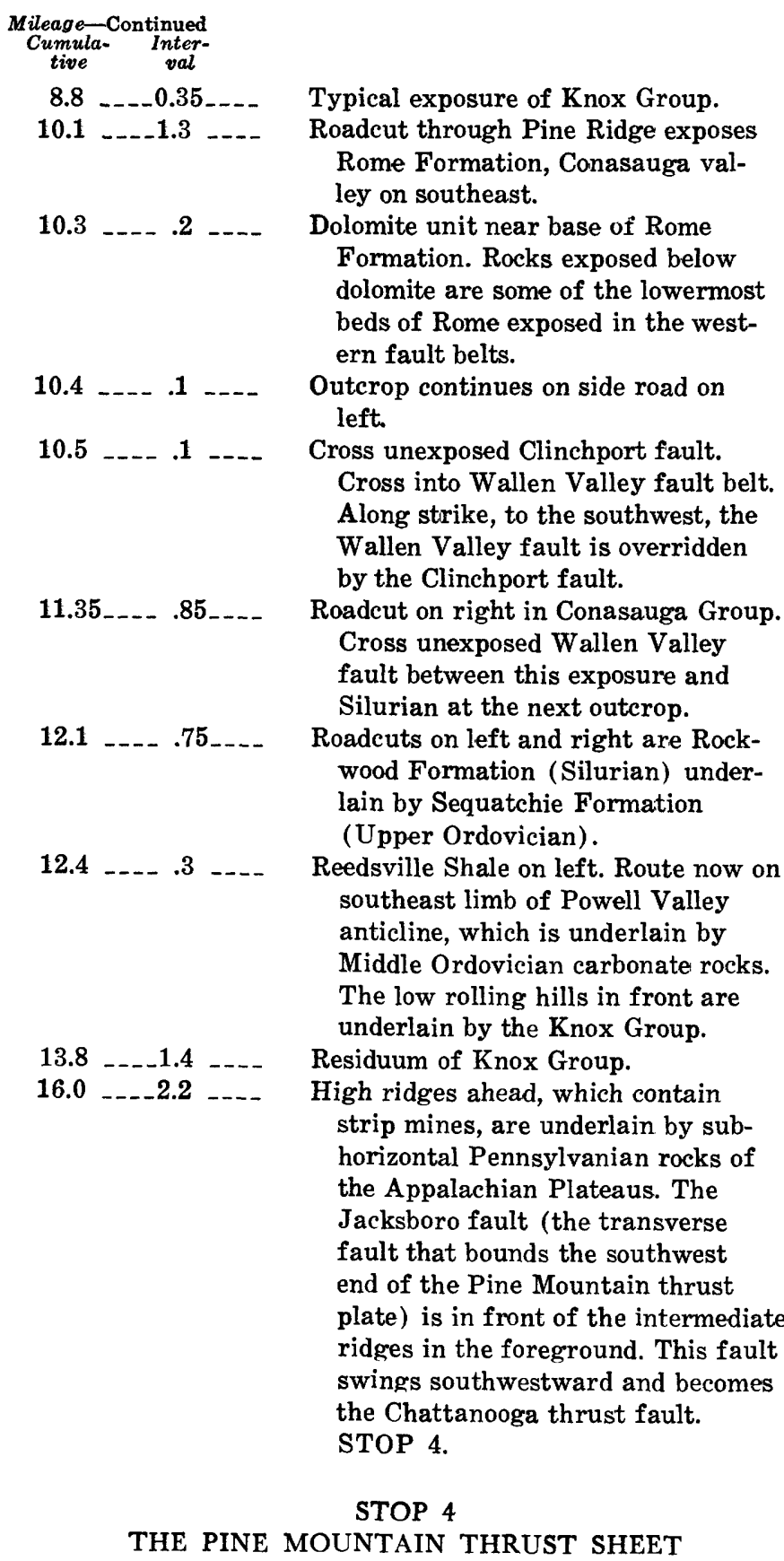

The Clinchport thrust fault is generally considered to be the southeast limit of the Pine Mountain thrust sheet (pl. 2). From this point on (mile 16), we will be making a surface cross-sectional traverse through the classic Pine Mountain structure.

The Pine Mountain thrust sheet, a distinct quadrilateral structure about 125 miles $(200 \mathrm{~km})$ long and 25 miles $(40 \mathrm{~km})$ wide, is bound on the northwest by the Pine Mountain thrust fault, on the southwest by the Jacksboro fault, and on the northeast by the Russell Fork fault. The sheet can be divided into two major features-the Middlesboro syncline on the northwest and the Powell Valley anticline to the southeast. Displacement on the Pine Mountain fault increases from about 4 miles (6.4 $\mathrm{km}$ ) at its northeast end (Englund, 1971) to about 11 miles $(17.6 \mathrm{~km})$ at its southwest end (Englund, 1968). An abundance of surface and subsurface data in the region indicates that the Pine Mountain sheet forms the distal part of a general pattern of deformation that decreases in intensity from the Piedmont on the east to the Appalachian Plateau on the west (pl. 6).

The following generalizations were made by Butts (1927), Rich (1934), and Miller and Fuller (1954) from the geologic relations shown in a single crosssection (section $F-F^{\prime}$, pl. 2) : The Pine Mountain thrust fault formed early in the Allegheny orogenic cycle as a low-angle fault in sedimentary rocks that were little deformed. Taking advantage of contrasts in rock competence, the fault started in incompetent Cambrian shaly zones within the Rome Formation or Conasauga Group, above the contact between basement and the Paleozoic sedimentary cover. It followed this near-basement contact zone westward to near the present-day Valley and Ridge-Plateaus contact. There it shifted abruptly upward across a competent zone along a steeply dipping diagonal fault and relocated as a bedding thrust in another incompetent shaly zone (the Chattanooga Shale). It continued at that level to the Pine Mountain area, where it was probably deflected to the surface by a splay anticline.

Although the basic geometry of the Pine Mountain fault was correctly identified in the Ewing section, sections (pl. 2) in other parts of the sheet demonstrate that along strike the initial fracture does not maintain the same stratigraphic position beneath the Pine Mountain thrust sheet (Harris, $1970)$. In section $E-E^{\prime}$ at the southwest end of the plate beneath the Powell Valley anticline, the Pine Mountain thrust is near the base of the Cambrian Rome Formation. Westward under the Middlesboro syncline, thinning of the Chattanooga Shale (Devonian and Mississippian) apparently caused the fault to form in a stratigraphically lower and thicker shaly zone at the base of the Silurian Rockwood Formation. Section $F-F^{\prime}$, which is the classical Ewing section, shows the Pine Mountain fault beneath the Powell Valley anticline to be stratigraphically higher than in section $E-E^{\prime}$, at the contact between the Conasauga Group (Middle and Upper Cambrian), and the Upper Cambrian and Lower Ordovician carbonate sequence. At the north- 
east end of the plate, where the Powell Valley anticline has plunged out, section $H-H^{\prime}$ shows that the fault had crosscut from the base of the Cambrian Rome Formation to the base of the Devonian shale sequence south of the Pine Mountain plate boundary. Thus, in that area, the thrust fault is at the Devonian level completely across the Pine Mountain plate.

These sections demonstrate that the Pine Mountain fault is a complex system that initially formed at different stratigraphic levels along, as well as across, strike (fig. 5). Apparently subsurface transverse faults act as connecting links, enabling lowangle thrust faults to form along strike at different stratigraphic levels; diagonal crosscut ramp faults are the connecting links that perform the same function normal to strike (Harris, 1970). Because the initial Pine Mountain fracture did not form at the same stratigraphic level throughout the Pine Mountain thrust sheet, movement across the irregular surface resulted in a rootless surficial anticline (Powell Valley anticline) characteristic of thinskinned deformation (fig. 9). The northwest limb of the anticline formed when beds in the crosscut zone moved upward and laterally so that the truncated edges of beds in that zone rotated to the subhorizontal surface of the Devonian-level thrust surface. The crestal area of the rootless anticline is a broad, relatively flat zone formed by the duplication of several thousand feet of section above the gently southeast-dipping Devonian-level thrust surface. The dip of the southeast limb is a reflection of the dip of the diagonal crosscut fault in the autochthonous plate.

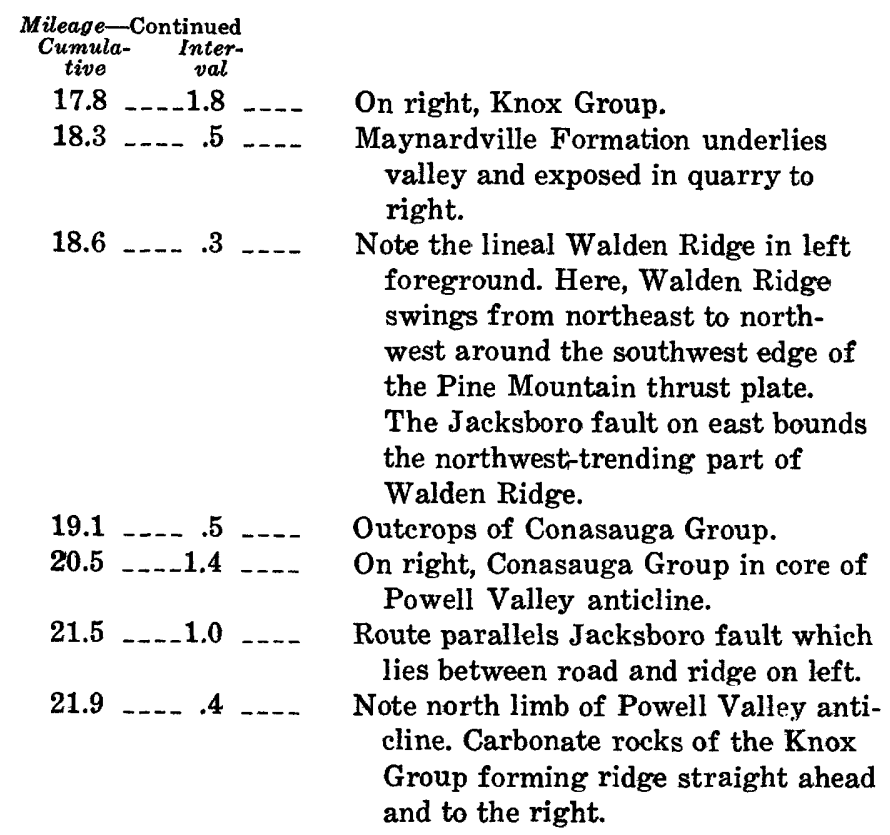

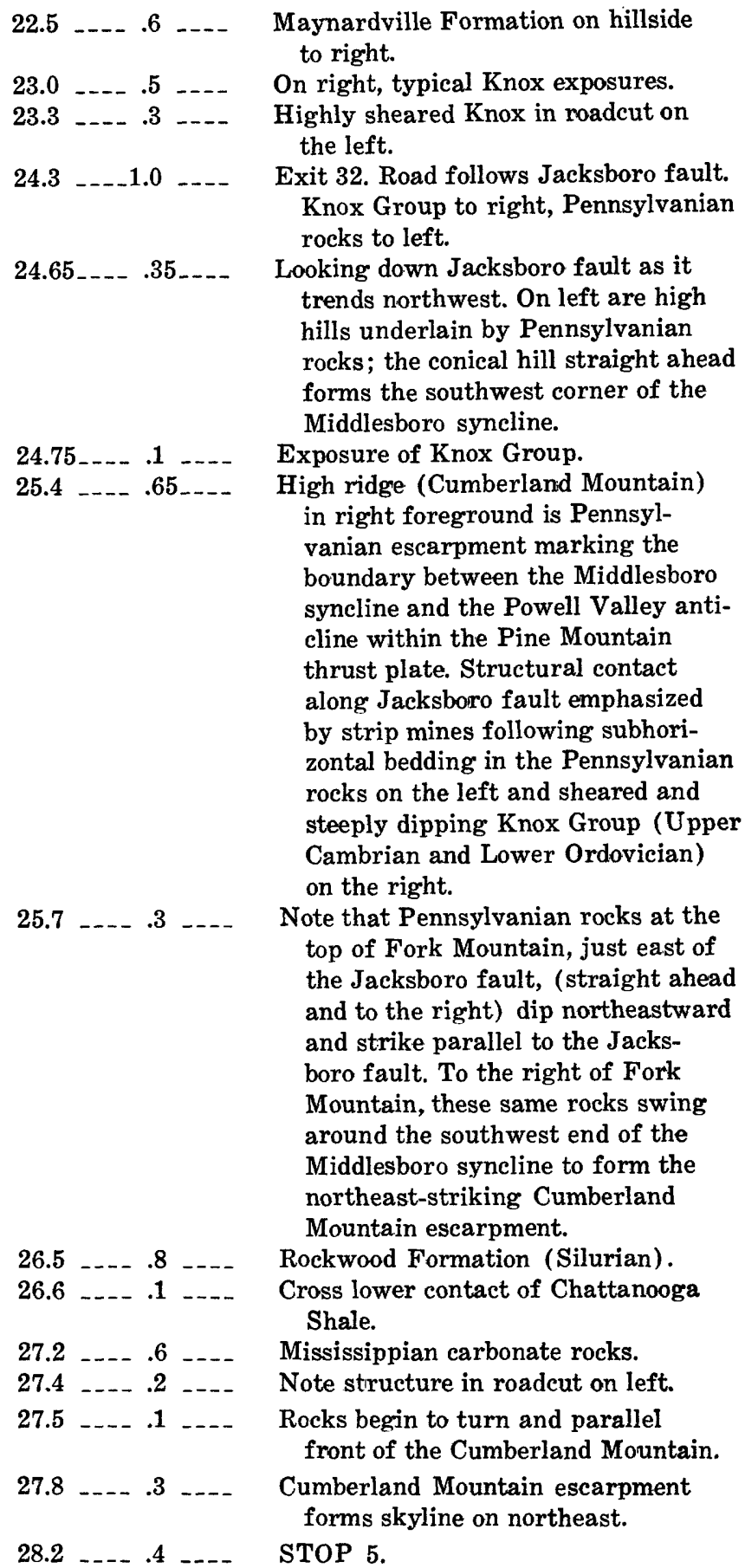

STOP 5

VERTICAL PENNSYLVANIAN RIBS IN THE NORTHWEST LIMB OF THE POWELL VALLEY ANTIGLINE

At this locality we are looking at the steeply dipping northwest limb of the Powell Valley anticline, a surficial structure confined to the rocks above the Pine Mountain thrust fault. In contrast, rocks in the subsurface below the Pine Mountain thrust are subhorizontal and have a gentle regional dip to the southeast (pl. 2, section $E-E^{\prime}$ ). Rocks 
of the northwest limb of the anticline have been displaced about 11 miles $(17.6 \mathrm{~km})$ northwestward from their root zone, which is in the subsurface beneath the south limb of the Powell Valley anticline. The northwest limb of the Powell Valley anticline was formed during movement, when beds in the crosscut zone in the allochthonous plate were moved up the tectonic ramp and rotated onto the next higher level subhorizontal detachment surface near the base of the Silurian Rockwood Formation in the autochthonous plate.

To the northwest beneath the Middlesboro syncline, the dip of the Pennsylvanian rocks in this limb of the anticline changes rapidly from near vertical to about $10^{\circ}$ to subhorizontal. This change in attitude reflects the subsurface beneath the Middlesboro syncline where the Pine Mountain thrust is no longer crosscutting rocks in the alloch thonous sheet. Instead, the fault is paralleling bedding in both hanging wall and footwall. The same relationship can be seen to the southeast, where steeply dipping Cambrian and Lower Ordovician rocks at the base of the northwest limb of the Powell Valley anticline change their attitude southward and become a gently undulating sequence across the broad core region of the anticline. The attitude of the rocks in the core region of the Powell Valley anticline, like the attitude of the rocks in the Middlesboro syncline, is simply a reflection of the parallelism of the Pine Mountain thrust in the subsurface to bedding in both hanging-wall and footwall rocks.

\begin{tabular}{|c|c|}
\hline $\begin{array}{c}\text { Mileage-Continued } \\
\text { Cumula- } \\
\text { tive }\end{array}$ & \\
\hline $28.4 \ldots$ & $\begin{array}{l}\text { Dip has changed from vertical to a } \\
\text { few degrees northwest. }\end{array}$ \\
\hline $28.6-\ldots .2 \ldots$ & $\begin{array}{l}\text { Pennsylvanian rocks gently dipping } \\
\text { to the northwest. }\end{array}$ \\
\hline $31.1 \quad \ldots-2.5 \quad \ldots$ & $\begin{array}{l}\text { From here on, we traverse subhori- } \\
\text { zontal beds of the Middlesboro } \\
\text { syncline. }\end{array}$ \\
\hline $32.1 \ldots$ & $\begin{array}{l}\text { High ridges on far left in Pennsyl- } \\
\text { vanian rocks beyond Pine Mountain } \\
\text { thrust plate are separated from } \\
\text { lineal ridge (Fork Mountain) in } \\
\text { foreground within the thrust sheet } \\
\text { by Jacksboro fault. }\end{array}$ \\
\hline $33.7-\ldots 1.6$ & $\begin{array}{l}\text { Flat-lying Pennsylvanian rocks. Road } \\
\text { continues on Pennsylvanian rocks } \\
\text { to Pine Mountain. }\end{array}$ \\
\hline $36.5 \quad \ldots-2.8 \quad$ & $\begin{array}{l}\text { Interstate turns northwest corner to } \\
\text { parallel Pine Mountain. Rocks dip } \\
\text { gently. }\end{array}$ \\
\hline $40.9-\ldots-4.4 \quad--$ & $\begin{array}{l}\text { On left, Pennsylvanian rocks across } \\
\text { Elk Valley northwest of Pine } \\
\text { Mountain thrust sheet have strip } \\
\text { mines in flat-lying Pennsylvanian } \\
\text { rocks in contrast to southeast-dip- }\end{array}$ \\
\hline
\end{tabular}

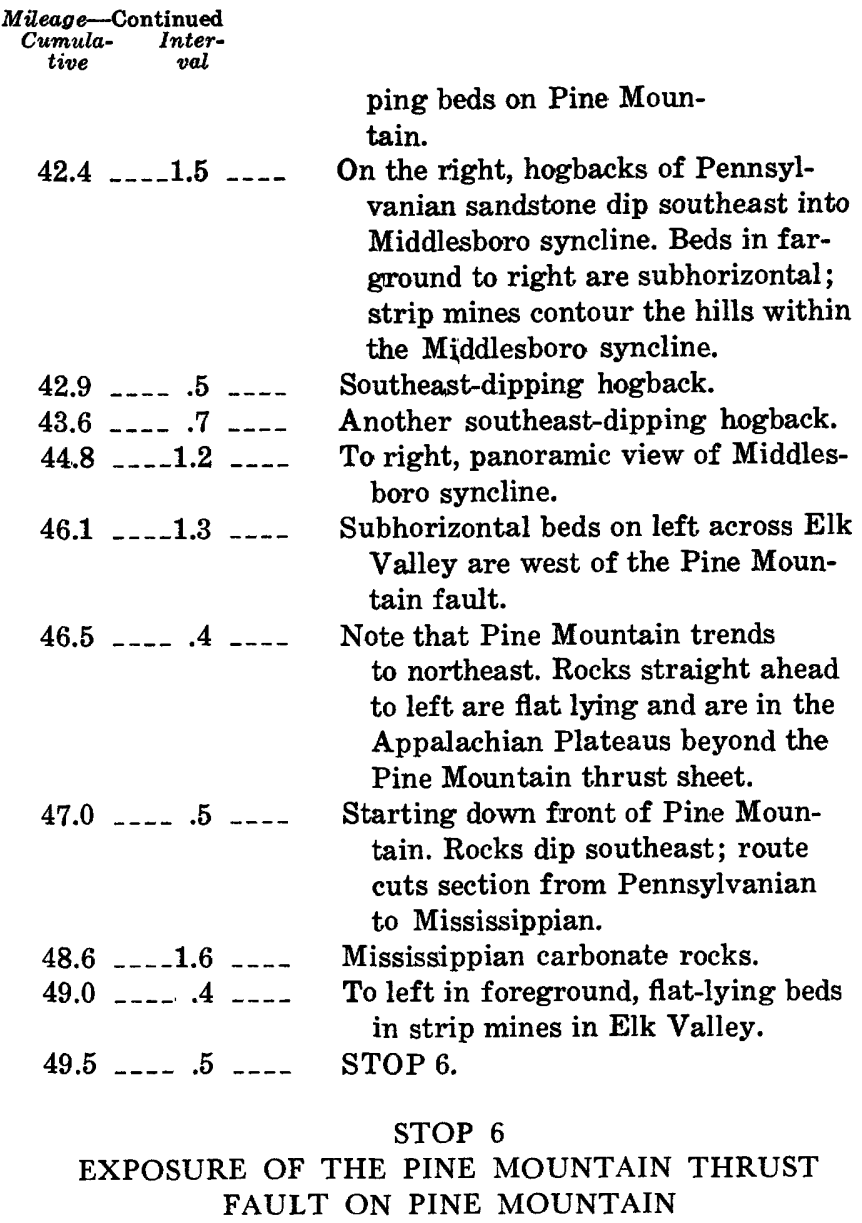

The Pine Mountain thrust fault at this locality places the Chattanooga Shale (Devonian and Mississippian) above subhorizontal Pennsylvanian rock (Englund, 1968). Rocks above the fault dip about $30^{\circ} \mathrm{SE}$., probably mimicking the dip of a tectonic ramp extending upward from the Chattanooga Shale to rocks of Pennsylvanian age (pl. 2). Because the fault exposure is on a hill slope, rather than a vertical roadcut, weathering tends to obscure most of the internal structural detail within the zone, although intense fracturing of the shale is readily apparent. The overlying rocks of Mississippian age, which are fully exposed in near-vertical roadcuts, show few structural characteristics like those of the upper fracture zone seen at Dunlap, indicating that the zone of fracture was very thin and largely confined to the Chattanooga Shale.

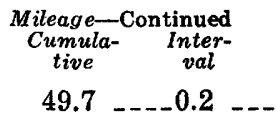

On left, subhorizontal coal bed of Pennsylvanian age. This coal bed is about 50 feet below the Pine Mountain fault. From here to Jellico, the route is on subhorizontal Pennsylvanian rocks. 


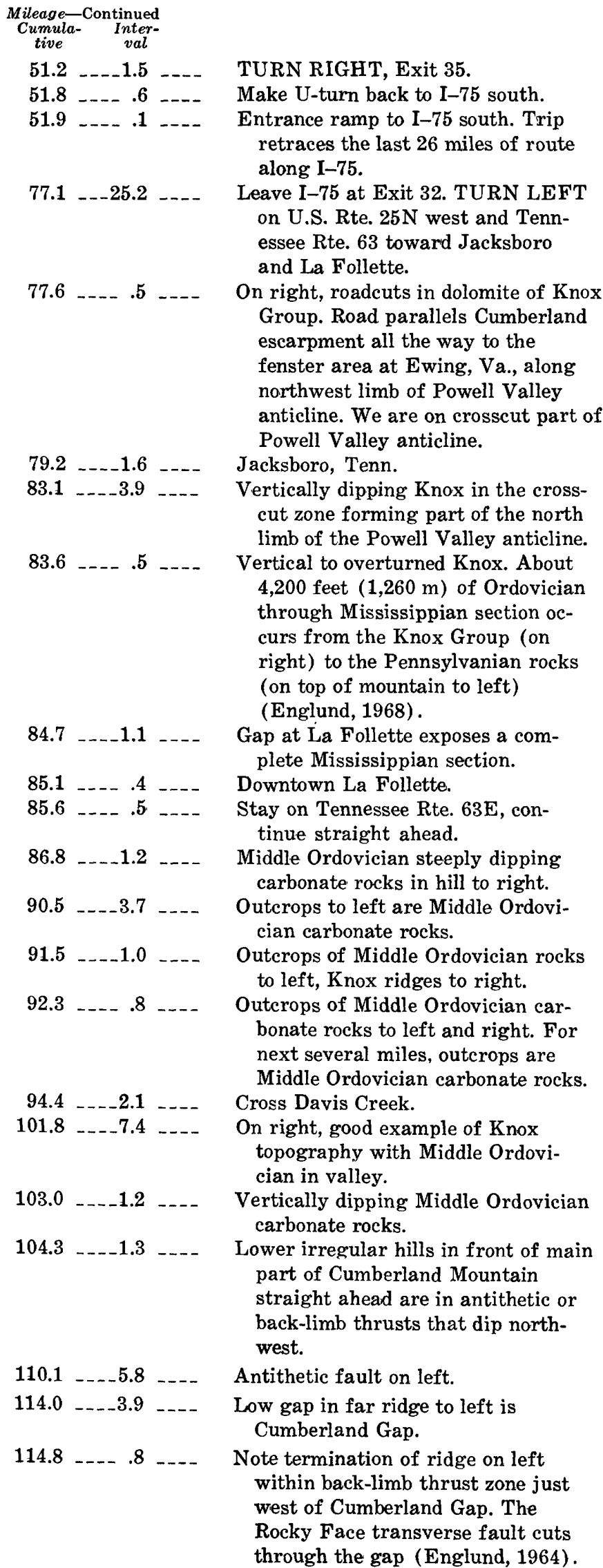

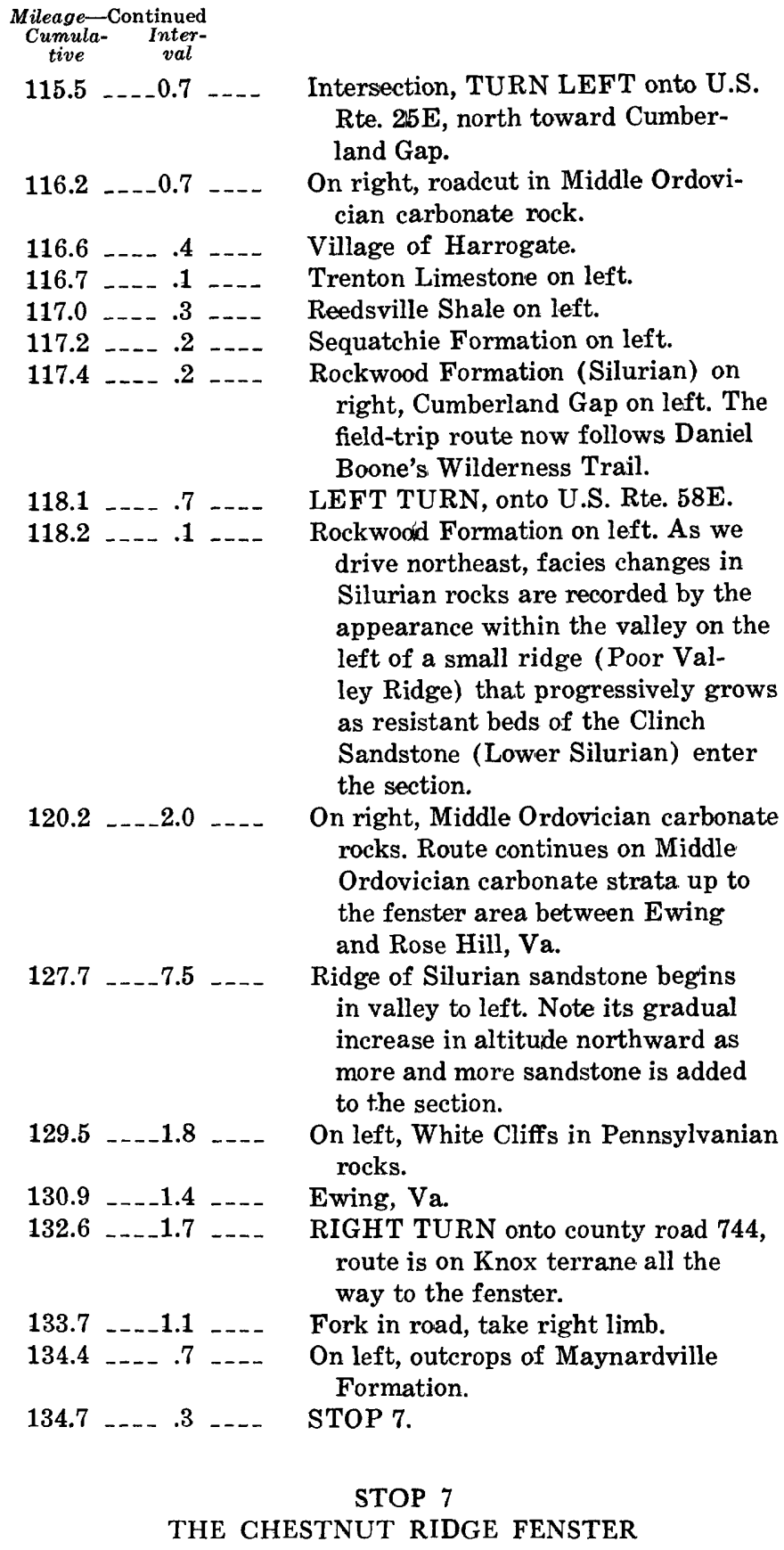

Ridge of Silurian sandstone begins in valley to left. Note its gradual increase in altitude northward as more and more sandstone is added to the section.

On left, White Cliffs in Pennsylvanian rocks.

Ewing, Va.

RIGHT TURN onto county road 744 , route is on Knox terrane all the way to the fenster.

Fork in road, take right limb.

On left, outcrops of Maynardville Formation.

STOP 7.

STOP 7

THE CHESTNUT RIDGE FENSTER

The Chestnut Ridge fenster is the southwesternmost of several fensters exposed along the axial region of the Powell Valley anticline (fig. 6). Butts (1927), upon discovery of the fensters, proposed that the Pine Mountain thrust, which heretofore was thought to dip steeply toward basement (Wentworth, 1921), was in reality a low-angle thrust, extending southwestward from Pine Mountain to the fenster area. Remarkably, although he had a minimum of surface data, Butts constructed a crosssection to near sea level that differs little from those produced today with the aid of subsurface control. 
Later, Rich (1934), utilizing the Butts data, formulated the general characteristics of thin-skinned deformation.

At this locality, the Pine Mountain fault is exposed on a side road leading to the right. The Pine Mountain fault brings the Maynardville Formation (Upper Cambrian) in contact with the Rose Hill Formation (Silurian) in the autochthonous plate. West of the intersection on the right side of the valley, the Pine Mountain fault is arched upward from road level to about 80 feet $(24 \mathrm{~m})$ above road level, thus carrying the Maynardville from road level to the tree line on the hill. The Rose Hill is generally in pasture land, whereas the rocky Maynardville is in woodland, making easy the demarcation of the Pine Mountain fault along the edge of the Chestnut Ridge fenster.

Surface and subsurface studies by Miller and Fuller (1954) and Miller and Brosgé (1954) throughout most of the fenster area of southwest Virginia clearly show that the Pine Mountain is arched on the order of 5,000 feet $(1,500 \mathrm{~m})$ beneath the Powell Valley anticline. Drilling by Shell Oil Co. south of the Chestnut Ridge fenster (fig. 10) determined that this arching was not the result of the folding process operating within the sedimentary prism; rather, arching resulted from subsurface duplication of more than 5,600 feet $(1,680 \mathrm{~m})$ of beds by the unexposed Bales thrust fault (Harris, 1967). The source of the duplicated beds is within the autochthonous plate beneath the Pine Mountain thrust, which is contrary to the generally accepted concept that rocks of that plate are passive elements in thin-skinned deformation (Rich, 1934). Oil exploration in the area has been confined to the Trenton in the duplicated slab, and the autochthonous plate below the slab has not been explored.

From this locality to the southwest edge of the fenster, we will traverse the truncated edges of the Rose Hill Formation, Clinch Sandstone, and Sequatchie Formation, all within the autochthonous plate. Exposed in a small quarry at $\mathbf{1 3 5 . 3}$ on the right side of the road is a fault slice of the Maynardville Formation, which on the road is in fault contact with a small slice of the Trenton Limestone. Detailed mapping of the Chestnut Ridge fenster (Miller and Fuller, 1954; Harris and others, 1962) shows that a series of fault slices of the Maynardville Formation and Knox Group exposed in the fenster intervenes between the older Cambrian rocks of the Pine Mountain thrust sheet and the younger formations in the autochthonous plate (fig. 6). This series of slices resembles the broken-formation zone that overlies the Pennsylvanian décollement at Dunlap. We suggest that these slices may be abandoned parts of the Knox derived from the broken-formation zone beneath the crosscut in the allochthonous plate (pl. 2).

This exposure of the Conasauga Group marks the southwest edge of the Chestnut Ridge fenster. Note on the map (fig. 6) the sharp stratigraphic change from east to west of the Pine Mountain fault from the base of the Maynardville Formation over the fenster to the Conasauga at this locality. Drilling west of the fenster shows that the Pine Mountain thrust changes stratigraphic position along strike to the southwest from the base of the Maynardville to near the base of the Rome Formation along a steeply dipping transverse fault (Harris, 1970). We interpret the sharp contact of fenster rocks and the Conasauga to be the trace of the transverse fault, which enabled the Pine Mountain fault to form along strike at different stratigraphic positions.

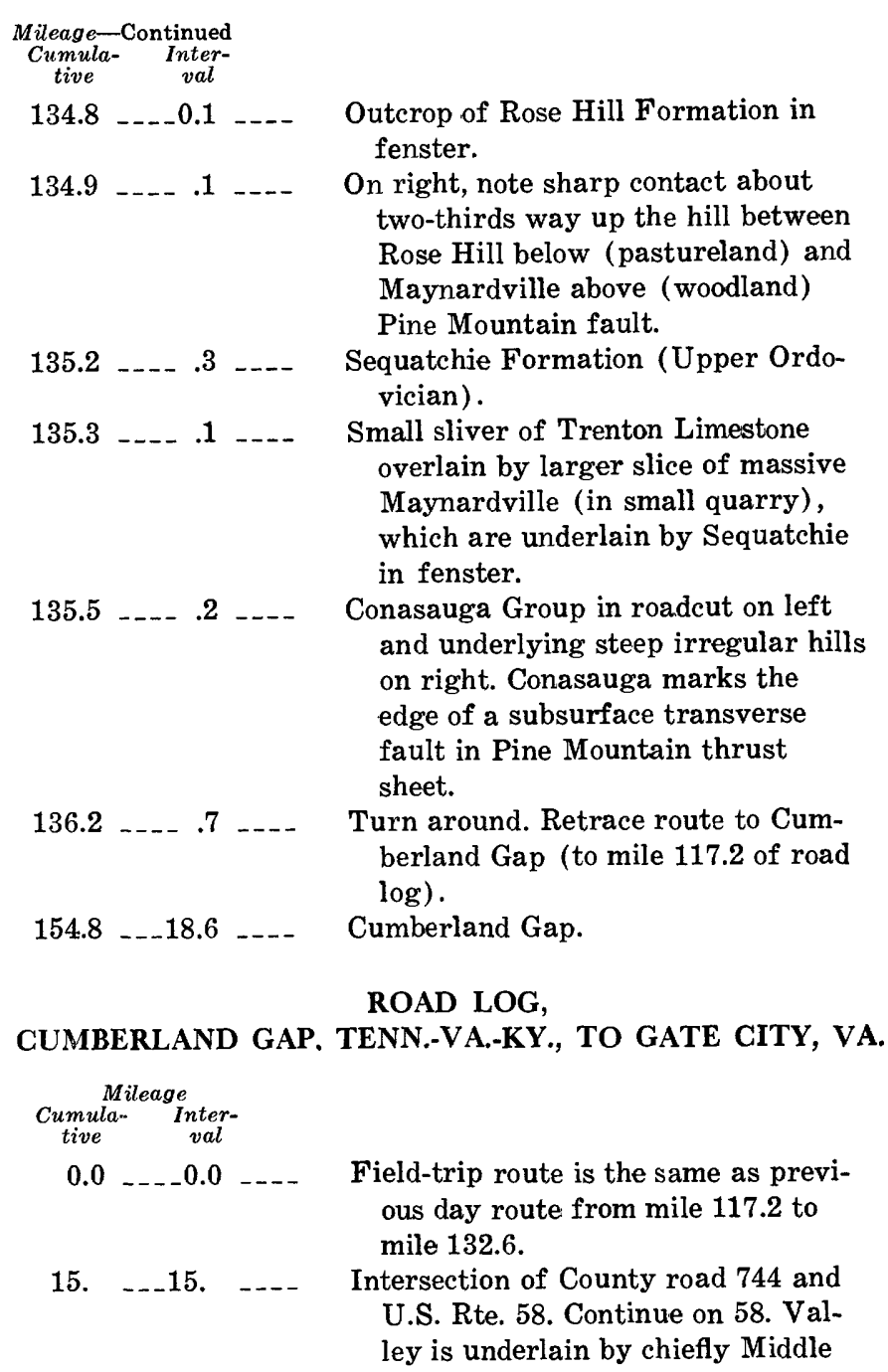




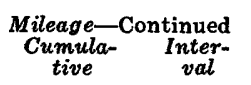

18.2

19.3

$21.8 \ldots--2.5 \ldots$

$22.2 \ldots . .4 \ldots$

$22.8+\ldots .6-\cdots$

23.1

24.2

25.9

$26.2+\ldots .3 \ldots$

27.1

$29.9---2.8$

$33.8+--3.9-\cdots$
Ordovician carbonate rocks. Fenster area continues to near Pennington Gap for a distance of about 25 miles $(40 \mathrm{~km}$ ).

Rose Hill, Va.

Road follows contact between Knox Group (forms hills to right) and Middle Ordovician carbonate rocks (in valley to left).

Note, on left, where land is allowed to return to its natural state, the terrain underlain by Middle Ordovician carbonate rocks develops cedar breaks.

Roadcuts to right and left in Middle Ordovician carbonate rocks.

A complete reference section of $\mathrm{Mid}$ dle Ordovician through Devonian rocks is exposed in a railroad cut about 1 mile $(1.6 \mathrm{~km})$ northwest on County road 621, Hagan, Va. (Miller and Brosgé, 1954).

Knox roadcuts on left. Route continues on Knox until mile 25.9.

On right, Anthony Ely well was drilled at this locale. Intersected Pine Mountain fault at depth of 643 feet $(193 \mathrm{~m})$ and encountered gas in Reedsville Shale below the fault. Even though well was plugged in 1947, it has continued to flare to the present day.

Middle Ordovician carbonate rock in fields to left.

Knox Group in roadcuts on right.

Route is on large broad area underlain chiefly by Knox Group.

On right, small roadcuts in Middle Ordovician carbonate rocks. On left is low rolling ridge of Knox Group. Road has just passed into Cedar syncline-very shallow syncline in middle of Powell Valley containing Middle Ordovician carbonate rocks in trough. The axial region of the Powell Valley anticline in this area is complex, so that the Cedars syncline is flanked on the north by the Chestnut Ridge anticline and on the south by the Sandy Ridge anticline. These small anticlines probably resulted from subsurface duplication; however, this is obvious only along the Chestnut Ridge anticline, where erosion has produced fensters along its crestline (fig. 11).

Narrow axial region of Cedar syncline-Knox ridges on left and right.

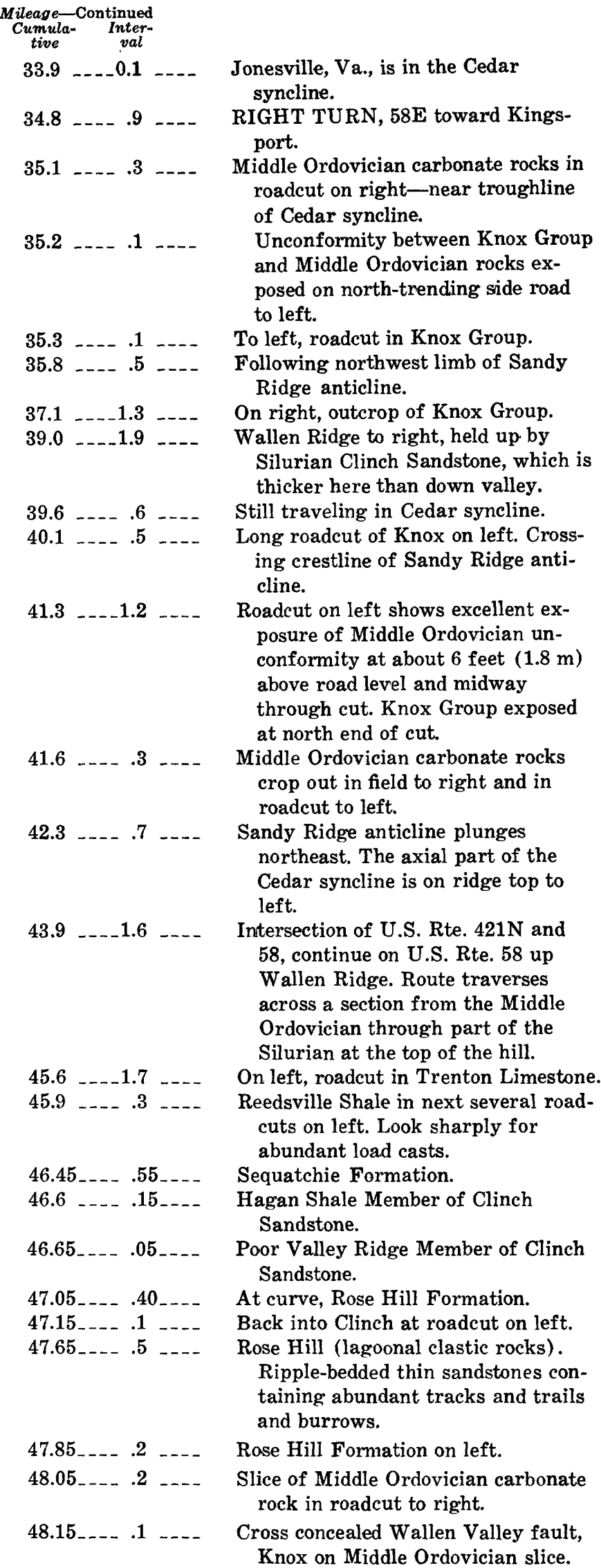

Jonesville, Va., is in the Cedar syncline.

RIGHT TURN, 58E toward Kingsport.

Middle Ordovician carbonate rocks in roadcut on right-near troughline of Cedar syncline.

Unconformity between Knox Group and Middle Ordovician rocks exposed on north-trending side road to left.

To left, roadcut in Knox Group.

Following northwest limb of Sandy Ridge anticline.

On right, outcrop of Knox Group.

Wallen Ridge to right, held up by Silurian Clinch Sandstone, which is thicker here than down valley.

Still traveling in Cedar syncline.

Long roadcut of Knox on left. Crossing crestline of Sandy Ridge anticline.

Roadcut on left shows excellent exposure of Middle Ordovician unconformity at about 6 feet $(1.8 \mathrm{~m})$ above road level and midway through cut. Knox Group exposed at north end of cut.

Middle Ordovician carbonate rocks crop out in field to right and in roadcut to left.

Sandy Ridge anticline plunges northeast. The axial part of the Cedar syncline is on ridge top to left.

Intersection of U.S. Rte. $421 \mathrm{~N}$ and 58, continue on U.S. Rte. 58 up Wallen Ridge. Route traverses across a section from the Middle Ordovician through part of the Silurian at the top of the hill.

On left, roadcut in Trenton Limestone.

Reedsville Shale in next several roadcuts on left. Look sharply for abundant load casts.

Sequatchie Formation.

Hagan Shale Member of Clinch Sandstone.

Poor Valley Ridge Member of Clinch Sandstone.

At curve, Rose Hill Formation.

Back into Clinch at roadcut on left.

Rose Hill (lagoonal clastic rocks). Ripple-bedded thin sandstones containing abundant tracks and trails and burrows.

Rose Hill Formation on left.

Slice of Middle Ordovician carbonate rock in roadcut to right.

Cross concealed Wallen Valley fault, Knox on Middle Ordovician slice. 


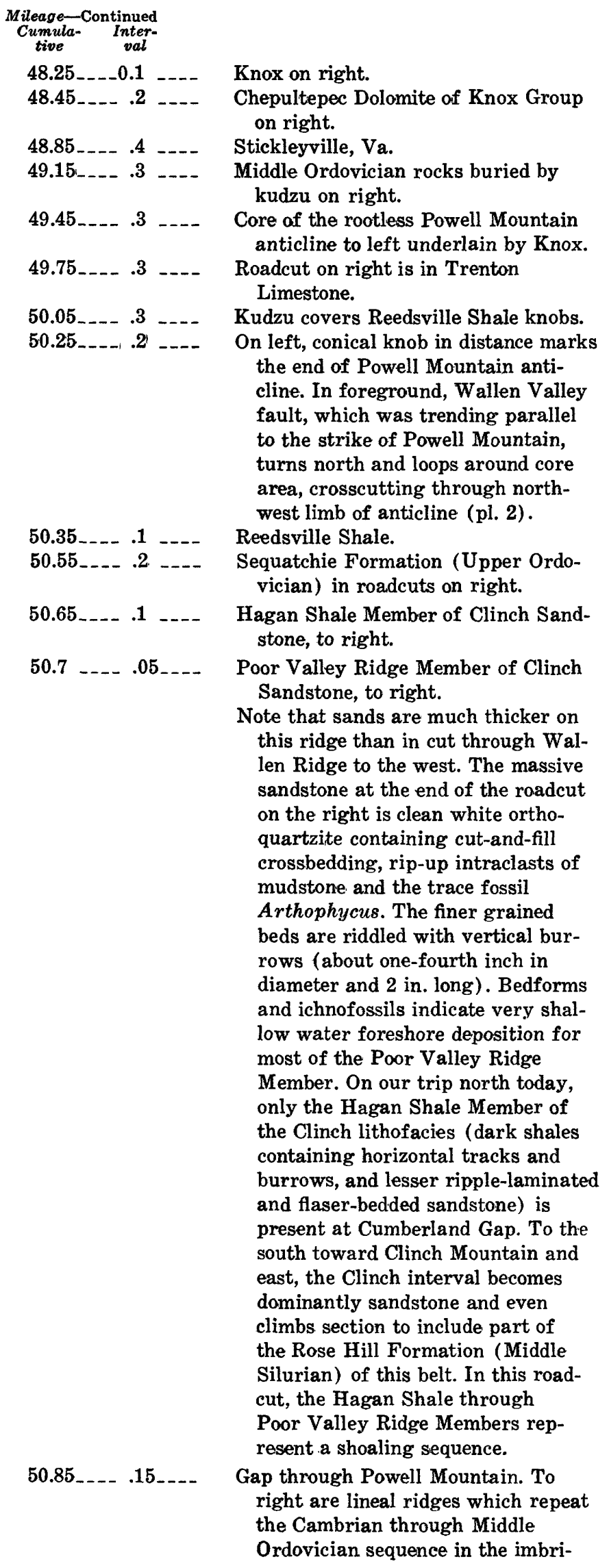

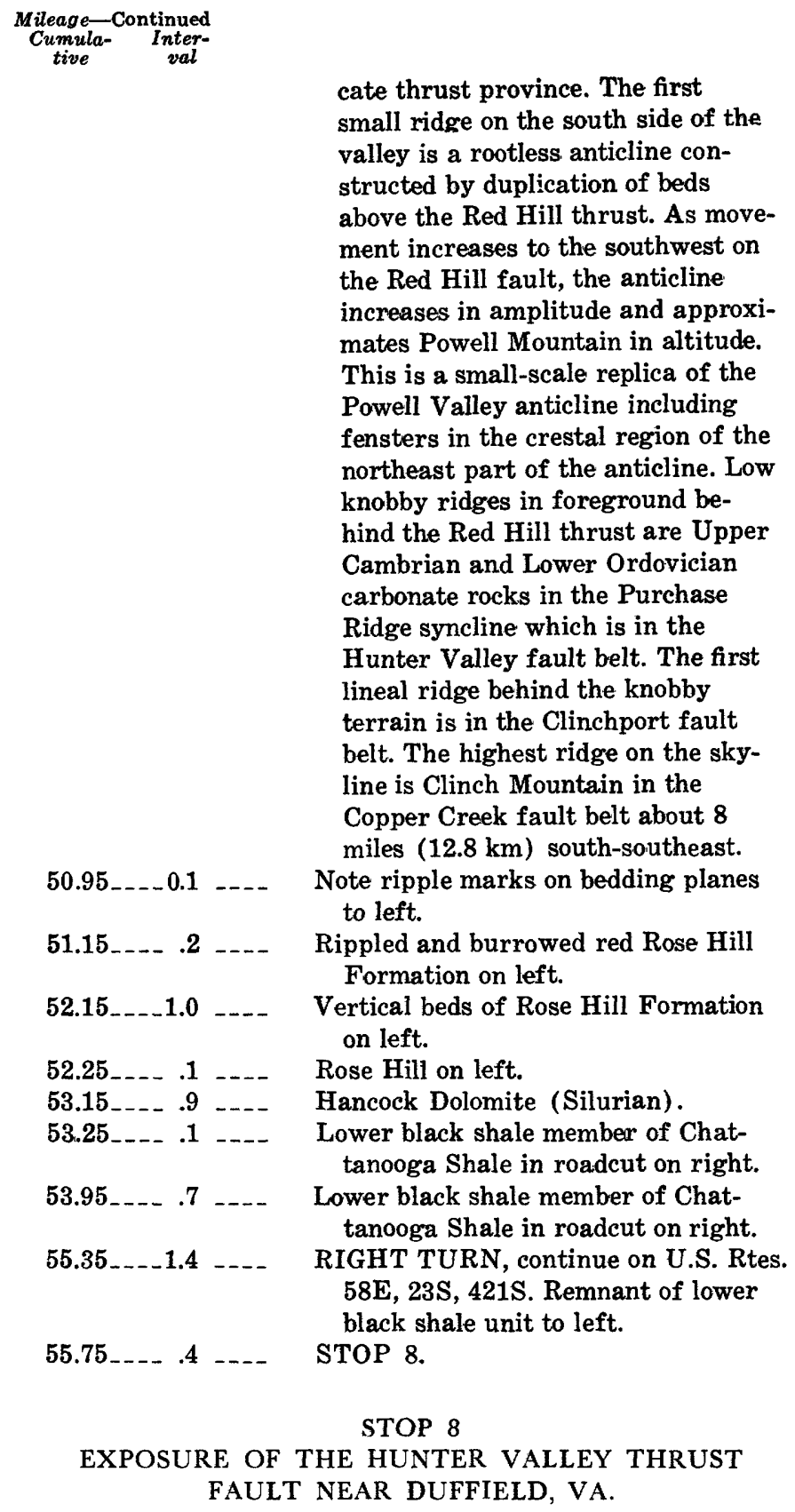

The Hunter Valley thrust brings Middle Cambrian shales and carbonate rocks in fault contact with the Devonian part of the Chattanooga Shale (pl. 9). The main purpose of this stop is to compare the details of the structure in a lower level décollement zone in shale and carbonate with those in the same zone in the terrigenous clastic rocks of the Rome Formation at Bull Run (stop 3). The lower broken-formation zone is not present above the detachment fault at this locality as it is at Bull Run. Instead, only the upper fracture zone is fully exposed. The type of structural feature present in the Duffield section is similar to the type present in 
the Bull Run section; compressional and tensional structures occupy successive intervals throughout the exposure. Although the type of structural feature is the same, the frequency of distribution appears to be much greater in the Duffield section.

\begin{tabular}{|c|c|}
\hline $\begin{array}{c}\text { Mileage-Continued } \\
\text { Cumula- } \\
\text { tive }\end{array}$ & \\
\hline $56.45_{-}-0_{0.7} \ldots$ & $\begin{array}{l}\text { Nolichucky Shale in roadcut on } \\
\text { right. Purchase Ridge syncline. }\end{array}$ \\
\hline $56.85 \ldots .4 \ldots$ & $\begin{array}{l}\text { Maynardville Formation in roadcut } \\
\text { on left. }\end{array}$ \\
\hline $57.15_{\ldots} \ldots .3 \ldots$ & $\begin{array}{l}\text { From here to Clinchport fault, ex- } \\
\text { posures to right and left are Knox } \\
\text { Group. }\end{array}$ \\
\hline $58.15 \ldots$ & $\begin{array}{l}\text { Axis of overturned southeast limb of } \\
\text { Purchase Ridge syncline. }\end{array}$ \\
\hline $58.45_{-}-.3 \ldots$ & $\begin{array}{l}\text { Axis of overturning of Purchase } \\
\text { Ridge sycline. }\end{array}$ \\
\hline $58.55_{\ldots} \ldots .1 \ldots$ & Knox in roadcut. \\
\hline $58.65_{\ldots-\ldots} .1 \ldots$ & Maynardville in roadcut on left. \\
\hline $58.75 \ldots \ldots .1 \ldots$ & Nolichucky Shale. \\
\hline $58.85 \ldots . .1 \ldots$ & $\begin{array}{l}\text { On right, Maryville Limestone of } \\
\text { Conasauga Group. }\end{array}$ \\
\hline $58.95 \ldots \ldots$ & Rogersville Shale on right. \\
\hline $59.05 \ldots .1 \ldots$ & Clinchport fault. \\
\hline $59.15 \ldots . .1 \ldots$ & $\begin{array}{l}\text { Roadcut on right in Rome Forma- } \\
\text { tion. }\end{array}$ \\
\hline $59.45 \ldots \ldots$ & $\begin{array}{l}\text { On right, shales at base of Cona- } \\
\text { sauga Group. }\end{array}$ \\
\hline $59.55 \ldots . .1 \ldots$ & $\begin{array}{l}\text { Pumpkin Valley Shale underlies } \\
\text { Pumpkin Valley. }\end{array}$ \\
\hline $59.65 \ldots . .1 \ldots$ & $\begin{array}{l}\text { Roadcuts on right and left expose } \\
\text { Rutledge Limestone, Rogersville } \\
\text { Shale, and Maryville Limestone. }\end{array}$ \\
\hline $59.85_{-} \ldots .2 \ldots$ & Nolichucky outerop on right. \\
\hline $60.05_{\ldots} \ldots .2 \ldots$ & $\begin{array}{l}\text { Turn off to Clinchport. Continuous } \\
\text { section of upper Nolichucky, May- } \\
\text { nardville, through Mascot Dolomite } \\
\text { of the Knox Group. }\end{array}$ \\
\hline $60.75_{-\ldots} .7 \ldots$ & $\begin{array}{l}\text { Middle Ordovician carbonate rocks } \\
\text { above Knox exposed in railroad cut } \\
\text { across river on left, but poorly ex- } \\
\text { posed in roadcuts on right. }\end{array}$ \\
\hline $60.95 \ldots .2 \ldots$ & Cross Copper Creek fault. \\
\hline $61.05_{-\ldots} .1 \ldots$ & $\begin{array}{l}\text { Poorly exposed Rome Formation to } \\
\text { right. }\end{array}$ \\
\hline $61.25 \ldots \ldots .2-\ldots$ & Maryville Limestone in cut to right. \\
\hline $61.45_{\ldots} \ldots .2 \ldots$ & Nolichucky underlies Clinch River. \\
\hline $61.65 \ldots . .2 \ldots$ & $\begin{array}{l}\text { Continuous exposure of Knox Group. } \\
\text { At this locality, the Knox is main- } \\
\text { ly dolomite; to the east, limestone } \\
\text { replaces dolomite and in the Pulaski } \\
\text { thrust belt, the section is almost } \\
\text { entirely limestone. }\end{array}$ \\
\hline $62.2 \ldots \ldots 5 \ldots$ & $\begin{array}{l}\text { Lower-Middle Ordovician boundary. } \\
\text { Traveling down strike valley of } \\
\text { Middle Ordovician rocks. At Cum- } \\
\text { berland Gap, the Middle Ordovi- } \\
\text { cian consists of } 1,500 \text { feet }(450 \mathrm{~m}) \\
\text { of chiefly carbonate rock, but here } \\
\text { the section consists of almost } 50 \\
\text { percent shaly limestone. }\end{array}$ \\
\hline
\end{tabular}

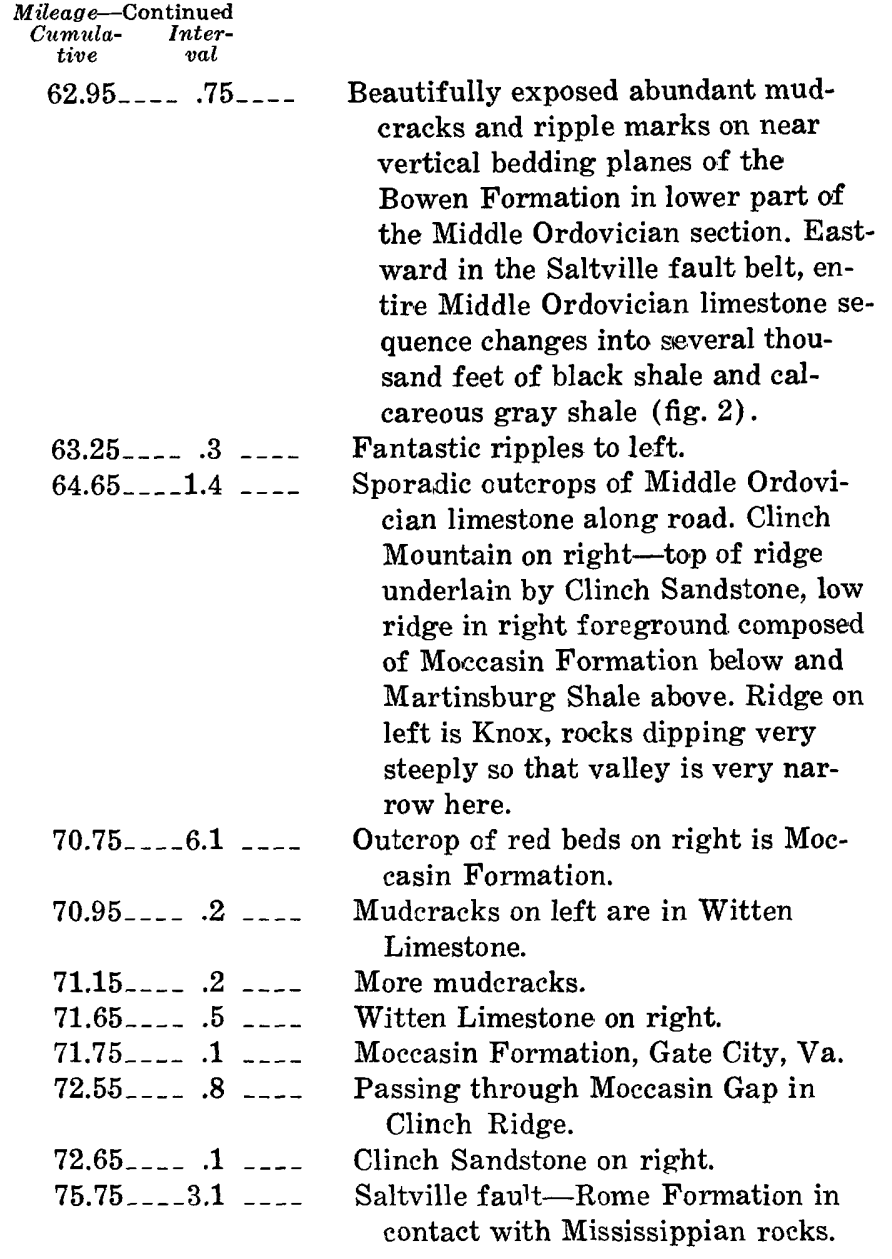

\section{REFERENCES CITED}

Averitt, Paul, 1941, The Early Grove gas field, Scott and Washington Counties, Virginia: Virginia Geol. Survey Bull. 56, $50 \mathrm{p}$.

Born, K. E., and Burwell, H. B., 1939, Geology and petroleum resources of Clay County, Tennessee: Tennessee Div. Geology Bull. 47, 188 p.

Brown, W. R., 1970, Investigations of the sedimentary record in the Piedmont and Blue Ridge of Virginia, in Fisher, G. W., and others, eds.: Studies of Appalachian geology-central and southern: New York, Interscience Publishers, p. 335-349.

Butts, Charles, 1927, Fensters in the Cumberland overthrust block in southwestern Virginia: Virginia Geol. Survey Bull. 28, $12 \mathrm{p}$.

Campbell, M. R., and others, 1925, The Valley coal fields of Virginia: Virginia Geol. Survey Bull. 25, 300 p.

Cattermole, J. M., 1966, Geologic map of the John Sevier quadrangle, Knox County, Tennessee: U.S. Geol. Survey Geol. Quad Map GQ-514.

de Witt, Wallace, Jr., 1974, Oil and gas data from the upper Paleozoic rocks in the Appalachian basin: U.S. Geol. Survey Misc. Geol. Inv. Map I-917-A.

de Witt, Wallace, Jr., Perry, W. J., Jr., and Wallace, L. G., 1975, Oil and gas data from Devonian and Silurian rocks in the Appalachian basin: U.S. Geol. Survey Misc. Geol. Inv. Map I-917-B. 
Englund, K. J., 1964, Geology of the Middlesboro South quadrangle, Tennessee-Kentucky-Virginia: U.S. Geol. Survey Geol. Quad. Map GQ-301.

— 1968, Geology and coal resources of the Elk Valley area, Tennessee and Kentucky: U.S. Geol. Survey Prof. Paper 572, $59 \mathrm{p}$.

- 1971, Displacement of the Pocahontas Formation by the Russell Fork fault, southwest Virginia: U.S. Geol. Survey Prof. Paper 750-B, p. B13-B16.

Epstein, A. G., Epstein, J. B., and Harris, L. D., 1976, Conodont color alteration-an index to organic metamorphism: U.S. Geol. Survey Prof. Paper 995, 27 p.

Ferm, J. C., Milici, R. C., and Eason, J. E., 1972, Carboniferous depositional environments in the Cumberland Plateau of southern Tennessee and northern Alabama: Tennessee Div. Geology Rept. Inv. 33, 32 p.

Froelich, A. J., 1973, Preliminary report of the oil and gas possibilities between Pine and Cumberland Mountains, southeastern Kentucky: Kentucky Geol. Survey Rept. Inv. 14, $12 \mathrm{p}$.

Glenn, L. C., 1925, The northern Tennessee coal field, included in Anderson, Campbell, Claiborne, Fentress, Morgan, Overton, Pickett, Roane, and Scott Counties: Tennessee Div. Geology Bull. 33-B, 478 p.

Glover, Lynn, 3d, 1959, Stratigraphy and uranium content of the Chattanooga Shale in northeastern Alabama, northwestern Georgia and eastern Tennessee: U.S. Geol. Survey Bull. 1087-E, p. 133-168.

Gwinn, V. E., 1964, Thin-skinned tectonics in the Plateau and northwestern Valley and Ridge provinces of the central Appalachians: Geol. Soc. America Bull., v. 75, no. 9, p. $863-900$.

Harris, L. D., 1967, Geology of the L. S. Bales well, Lee County, Virginia-a Cambrian and Ordovician test, in Proceedings of the Technical Session, Kentucky Oil and Gas Association, 29th Ann. Mtg., June 3-4: Kentucky Geol. Survey, ser. 10, Spec. Pub. 14, p. 50-55.

- 1970, Details of thin-skinned tectonics in parts of Valley and Ridge and Cumberland Plateau provinces of the southern Appalachians, in Fisher, G. W., and others, eds., Studies of Appalachian geology-central and southern: New York, Interscience Publishers, p. 161-173.

- 1971, A lower Paleozoic paleoaquifer-the Kingsport Formation and Mascot Dolomite of Tennessee and southwest Virginia: Econ. Geology, v. 66, no. 5, p. 735743.

1973, Dolomitization model for Upper Cambrian and Lower Ordovician carbonate rocks in the eastern United States: U.S. Geol. Survey Jour. Research, v. 1, no. 1, p. 63-78.

1976, Thin-skinned tectonics and potential hydrocarbon traps-illustrated by a seismic profile in the Valley and Ridge province of Tennessee: U.S. Geol. Survey Jour. Research, v. 4, no. 4, p. 379-386.

Harris, L. D., and Milici, R. C., 1976, Similarities of the Pine Mountain thin-skinned structural model to the Blue Ridge [abs.]: Geol. Soc. America, Abs. with Programs, v. 8, no. 2, p. 190.

Harris, L. D., and Miller, R. L., 1958, Geology of the Duffield quadrangle, Virginia: U.S. Geol. Survey Geol. Quad. Map GQ-111.

Harris, L. D., Stephens, J. G., and Miller, R. L., 1962, Geology of the Coleman Gap quadrangle, Tennessee-Virginia: U.S. Geol. Survey Geol. Quad. Map GQ-188.
Hayes, C. W., 1891, The overthrust faults of the southern Appalachians: Geol. Soc. America Bull., v. 2, p. 141154.

Huddle, J. W., Jacobsen, E. T., and Williamson, A. D., 1956, Oil and gas wells drilled in southwestern Virginia before 1950: U.S. Geol. Survey Bull. 1027-L, p. 501-573.

Jacobeen, Frank, Jr., and Kanes, W. H., 1974, Structure of Broadtop synclinorium and its implications for Appalachian structural style: Am. Assoc. Petroleum Geologists Bull., v. 58, no. 3, p. 362-375.

Kellberg, J. M., and Grant, L. F., 1956, Coarse conglomerates of the Middle Ordovician in the southern Appalachian Valley: Geol. Soc. America Bull., v. 67, no. 6, p. 697716.

King, P. B., 1960, The anatomy and habitat of low-angle thrust faults: Am. Jour. Sci., v. 258-A (Bradley Volume), p. 115-125.

King, P. B., and Beikman, H. M., compilers, 1974, Geologic map of the United States (exclusive of Alaska and Hawaii) : U.S. Geol. Survey, 3 sheets, scale 1:2,500,000.

King, P. B., and Ferguson, H. W., 1960, Geology of northeasternmost Tennessee: U.S. Geol. Survey Prof. Paper $311,136 \mathrm{p}$.

Lowry, W. D., ed., 1964, Tectonics of the southern Appalachians: Virginia Polytech. Inst. Dept. Geol. Sci. Mem. $1,114 \mathrm{p}$.

1971, Appalachian overthrust belt, Montgomery County, southwestern Virginia, in Guidebook to Appalachian tectonics and sulfide mineralization of southwestern Virginia: Virginia Polytech. Inst. State Univ., Dept. Geol. Sci. Guidebook no. 5, p. 143-165.

Luther, E. T., Hershey, R. E., and Swingle, G. D., 1963, Geologic map of the Fairmount quadrangle, Tennessee: Tennessee Div. Geology Geol. Map GM 105-NE, separate text.

McFarlan, A. C., 1943, Geology of Kentucky: Lexington, $\mathrm{Ky}$, Univ. Kentucky, 531 p.

Mellon, F. F., 1974, Possible Ordovician carbonate reservoirs in Mississippi: Am. Assoc. Petroleum Geologists Bull., v. 58 , no. 5 , p. $870-876$.

Milici, R. C., 1970, The Allegheny structural front in Tennessee and its regional tectonic implications: Am. Jour. Sci., v. 268, no. 2, p. 127-141.

- 1974, Stratigraphy and depositional environments of Upper Mississippian and Lower Pennsylvanian rocks in the southern Cumberland Plateau of Tennessee, in Briggs, Garrett, ed., Carboniferous of the southeastern United States: Geol. Soc. America Spec. Paper 148, p. 115-133.

1975, Structural patterns in the southern Appalachians-Evidence for a gravity slide mechanism for Alleghanian deformation: Geol. Soc. America Bull., v. 86, no. 9, p. 1316-1320.

Milici, R. C., Brent, W. B., and Walker, K. R., 1973, Depositional environments in upper Conasauga lagoon-fill sequence, in Geology of Knox County, Tennessee: Tennessee Div. Geology Bull. 70, p. 138-148.

Milici, R. C., and Harris, L. D., 1976, Structural subdivision of the Valley and Ridge and Appalachian Plateaus physiographic provinces [abs.]: Geol. Soc. America, Abs. with Programs, v. 8, no. 2, p. 229-230. 
Milici, R. C., and Leamon, A. R., 1975, Cranmore CoveChattanooga fault system-A model for the structure along the Allegheny front in southern Tennessee: Geology, v. 3, no. 3, p. 111-113.

Milici, R. C., and Smith, J. W., 1969, Stratigraphy of the Chickamauga Supergroup in its type area, in Precambrian-Paleozoic Appalachian problems: Georgia Geol. Survey Bull. 80 , p. 1-35; reprinted as Tennessee Div. Geology Rept. Inv. 24.

Miller, B. M., 1975, A summary of oil and gas production and reserve histories of the Appalachian basin, 18591972: U.S. Geol. Survey Bull. 1409, 36 p.

Miller, R. L., 1975, Oil and gas data from the Upper and Middle Ordovician rocks in the Appalachian basin: U.S. Geol. Survey Misc. Geol. Inv. Map I-917-C.

Miller, R. L., and Brosgé, W. P., 1954, Geology and oil resources of the Jonesville district, Lee County, Virginia: U.S. Geol. Survey Bull. 990, 240 p.

Miller, R. L., and Fuller, J. O., 1954, Geology and oil resources of the Rose Hill district-the fenster area of the Cumberland overthrust block-Lee County, Virginia: Virginia Geol. Survey Bull. 71, 383 p.

Pavlides, Louis, Sylvester, K. A., Daniels, D. L., and Bates, R. G., 1974, Correlation between geophysical data and rock types in the Piedmont and Coastal Plain of northeast Virginia and related areas: U.S. Geol. Survey Jour. Research, v. 2 , no. 5 , p. 569-580.

Ray, E. O., 1971, Petroleum potential of eastern Kentucky, in v. 2 of Future petroleum provinces of the United States-their geology and potential: Am. Assoc. Petroleum Geologists Mem. 15, p. 1261-1268.

Rich, J. L., 1934, Mechanies of low-angle overthrust faulting as illustrated by Cumberland thrust block, Virginia, Kentucky, and Tennessee: Am. Assoc. Petroleum Geologists Bull., v. 18, no. 12, p. 1584-1596.

Rodgers, John, 1949, Evolution of thought on structure of middle and southern Appalachians: Am. Assoc. Petroleum Geologists Bull., v. 33, no. 10, p. 1643-1654.

Ryan, W. M., 1974, Structure and hydrocarbon production associated with Pine Mountain thrust system in western Virginia [abs.]: Am. Assoc. Petroleum Geologists Bull., v. 58, no. 9, p. 1894.
Statler, A. T., 1975, Recent oil and gas activities in Tennessee: Am. Inst. Mining, Metallurgical and Petroleum Engineers, Soc. Petroleum Engineers, Paper SPE 5449, preprint, 8 p.

Stearns, R. G., 1954, The Cumberland Plateau overthrust and geology of the Crab Orchard Mountains area, Tennessee: Tennessee Div. Geology Bull. 60, 47 p.

Swingle, G. D., 1964, Elevation of the Chickamauga Limestone to group status in east Tennessee [abs.]: Tennessee Acad. Sci. Jour., v. 39, no. 2, p. 66.

Swingle, G. D., Palmer, R. A., Skinner, R. B., Hawkins, J. O., and McReynolds, J. L., Jr., 1967, Geologic map of the Luttrell quadrangle, Tennessee: Tennessee Div. Geology Geol. Map GM 155-NW.

Wanless, H. R., 1946, Pennsylvanian geology of a part of the Southern Appalachian coal field: Geol. Soc. America Mem. 13, 162 p.

Webb, E. J., 1972, Stratigraphic relationships of certain Mississippian-age pools in southeastern Kentucky and northeastern Tennessee, in Proceedings of Technical Session, Kentucky Oil and Gas Association, 34th and 35th Ann. Mtgs., 1970-1971: Kentucky Geol. Survey, ser. 10, Spec. Pub. 21, p. 50-58.

Wentworth, C. K., 1921, Russell Fork fault, in The geology and coal resources of Dickerson County, Virginia: Virginia Geol. Survey Bull. 21, p. 53-67.

Whisonant, R. C., 1974, Petrology of the Chilhowee Group (Cambrian and Cambrian(?)) in central-eastern and southern Tennessee: Jour. Sed. Petrology, v. 44, no. 1, p. 228-241.

Willoughby, Ralph, 1976, Lower and Middle Cambrian fossils from the Shady Formation, Austinville, Virginia [abs.]: Geol. Soc. America, Abs. with Programs, v. 8, no. 2, p. 301-302.

Wilson, C. W., Jr., and Stearns, R. G., 1958, Structure of the Cumberland Plateau, Tennessee: Geol. Soc. America Bull., v. 69 , no. 10 , p. $1283-1296$.

Wilson, C. W., Jewell, J. W., and Luther, E. T., 1956, Pennsylvanian geology of the Cumberland Plateau: Nashville, Tenn., Tennessee Div. Geology [folio], 21 p. 